\title{
Leadership pathways for local women: Case studies of three communes in Cambodia
}

\section{TEM LY}

\author{
A thesis \\ submitted to the Victoria University of Wellington in \\ fulfilment of the requirements for the degree of \\ Masters of Development Studies
}

School of Geography, Environment and Earth Sciences

Victoria University of Wellington 2015 



\begin{abstract}
Women in leadership are necessary for the development of Cambodia. Their involvement in leadership roles in the public sphere and politics is crucial and has been shown to impact positively on poverty reduction. Governments, NGOs and international organizations have been increasingly aware that development is significantly linked to gender. It is noted that sustainable development should focus on gender equality and that women's empowerment is a key factor in ending extreme poverty. Thus, a developing country like Cambodia should aim to empower women at the grassroots level. This study aims to facilitate how this may be achieved.

The lack of representation of women in local politics in Cambodia has recently been considered as a problem which can slow the progress of local development. This study uses case studies to understand the complexity of some women's real-life situations (life experience, behaviours, and emotions) and to explore the patterns of women becoming leaders at local levels. Three communes in the North-Eastern provinces, Kampong Cham, Kratie and Steung Treng provide the empirical base of the study. The study poses three main research questions: firstly, what type of work, personal characteristics and resources influence women to become local leaders? Secondly, what experiences do female local leaders have? Lastly, what can be learned from women's backgrounds and experiences to assist in the formation of a practical leadership model to help guide other women aspiring to be local leaders? In answering this last research question, the study concludes by offering a practical leadership model that is intended to help increase women's participation in local politics.

This study found that to achieve leadership, women need to build up their local work experience. Secondly, certain personal characteristics need to be developed, including a minimum education level, personal drive, confidence, gentleness, softness, integrity and friendliness. These internal factors gain people's trust, acknowledgement and support. Lastly, women need the continuing support of government, NGOs, family, villagers and others, including political parties. Greater opportunities for women to get involved in local politics will enable them to have access to local work experience, so they can build their own capacity, and enrich their education. The findings will assist organisations and women to plan for leadership and to create and make the most of opportunities.
\end{abstract}




\section{Dedication}

This is dedicated to my family and my beloved husband, Vuthy Chan. He has been very supportive and has given me the confidence to challenge myself and seek out my dream. His encouragement has allowed me to follow and achieve my study. 


\section{Acknowledgements}

I am grateful to each of the female local leaders and others who participated in this study. This research would not have been a success without your input. I acknowledge the New Zealand Agency for International Development (NZAID) who financially supported my Master's degree process in New Zealand. I wish to express my appreciation to Dr Rachel Tallon, and the staff of the Victoria Library and the Student Learning Support Service (SLSS) for assisting me with collecting books, journals, other sources, and for editing my English. To my supervisors, Dr Carol Harrington and Associate Professor Sara Kindon, I express my sincere gratitude for guiding me throughout the hard work of this degree with fortitude and assurance. Thank you all so much for being a part of this thesis. Without each of your efforts I could not have succeeded. 


\section{Table of Contents}

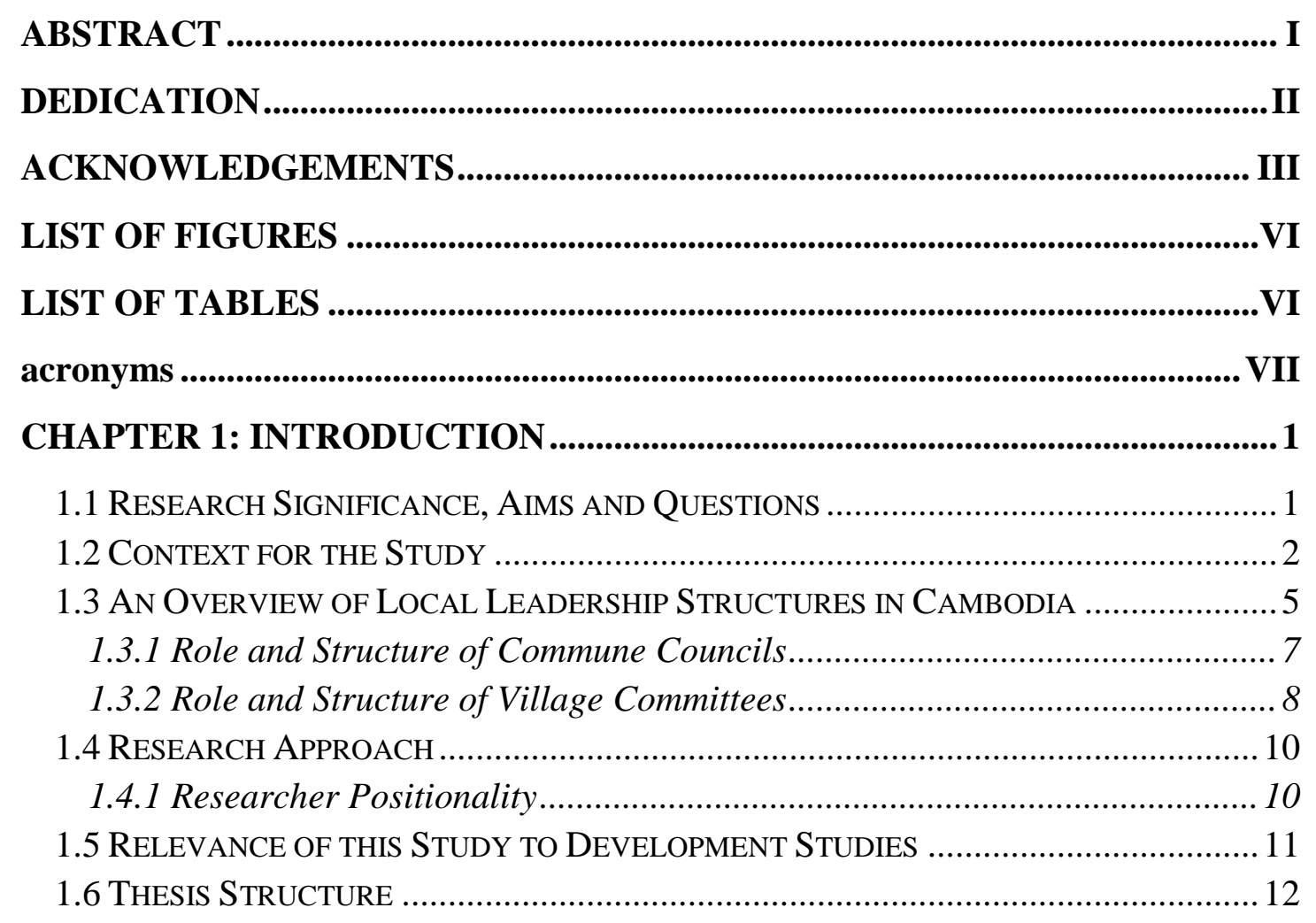

CHAPTER 2: THEORETICAL BACKGROUND............................................... 14

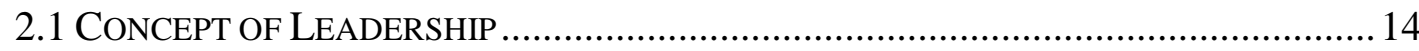

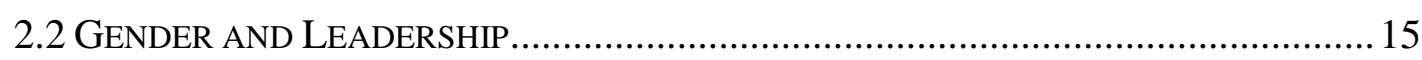

2.3 How WoMEN ALL OVER THE WORLD BECOME LEADERS .................................... 16

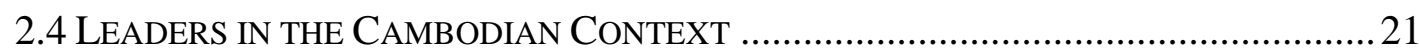

2.4.1 Who Are Considered Local Leaders in Cambodia? .................................... 21

2.4.2 Women Leaders in the Cambodian Context .............................................. 22

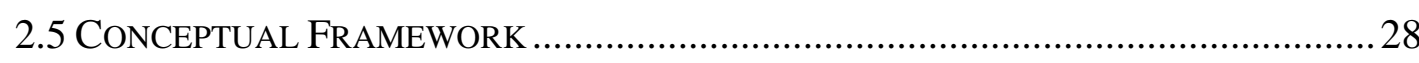

CHAPTER 3: METHODOLOGY .............................................................................30

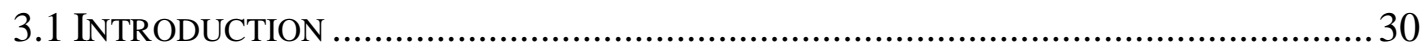

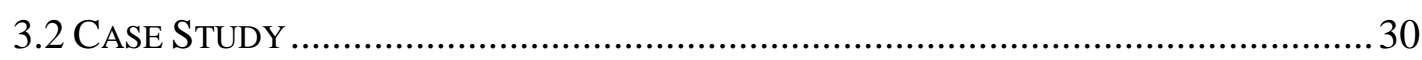

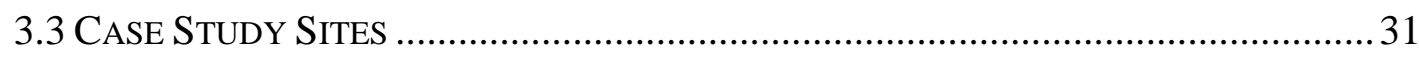

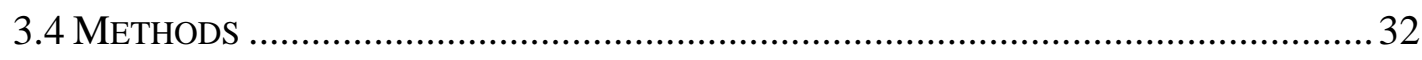

3.4.1 Protocols and the Fieldwork Process …….................................................. 33

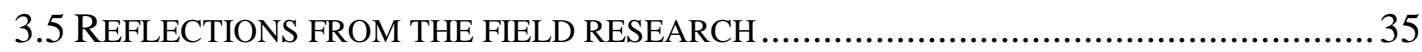

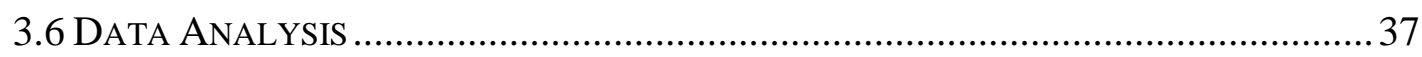

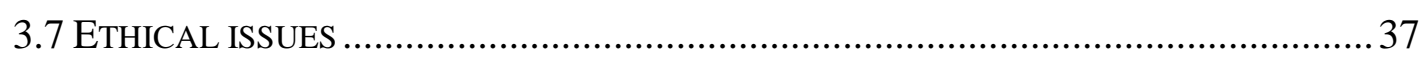

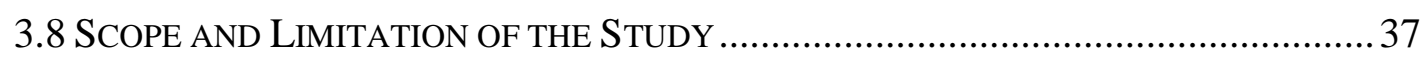

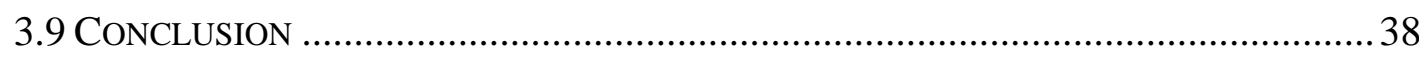

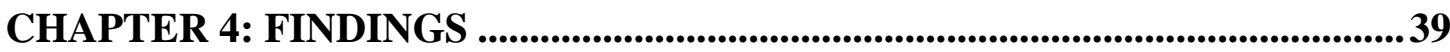




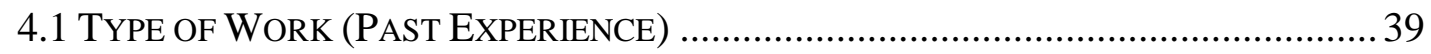

4.1.1 Female Village Leaders ............................................................................ 40

4.1.2 Female Commune Councillors ................................................................. 41

4.1.3 Female Commune Chiefs .............................................................................. 43

4.1.4 Conclusion for the Relevance of Type of Work Experience..........................4 44

4.2 PERSONAL CHARACTERISTICS (INTERNAL FACTORS) ......................................... 45

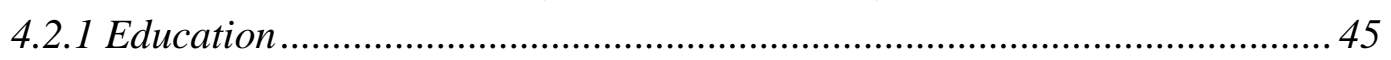

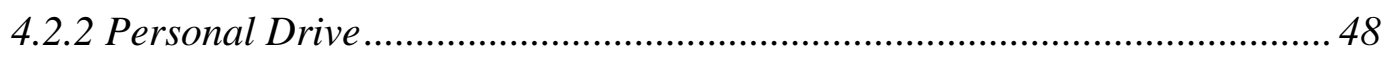

4.2.3 Bravery/Confidence .............................................................................. 52

4.2.4 A Gentle/Soft/Moral/Friendly Character................................................... 56

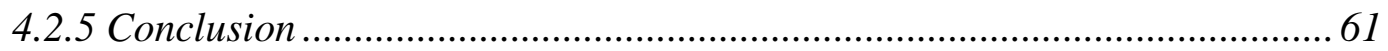

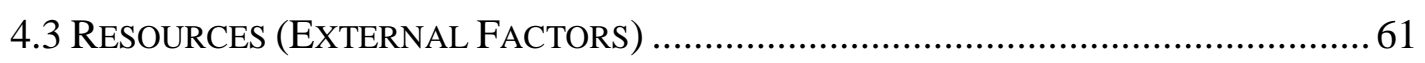

4.3.1 Reforms/Policies at the Institutional Level .................................................. 62

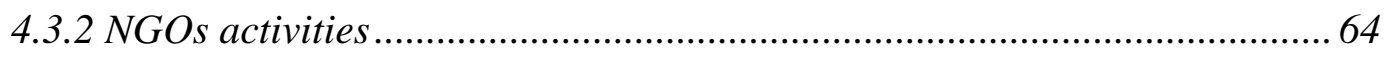

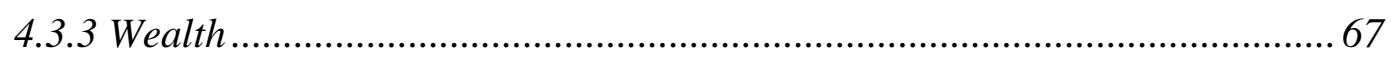

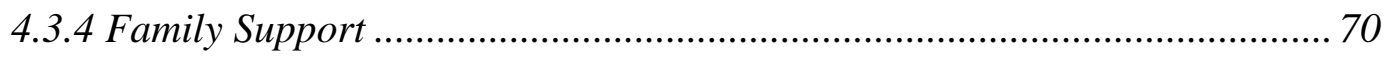

4.3.5 Villagers' Support and Others' Mentoring................................................ 74

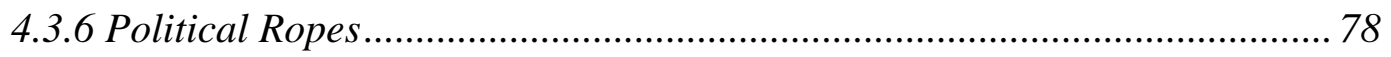

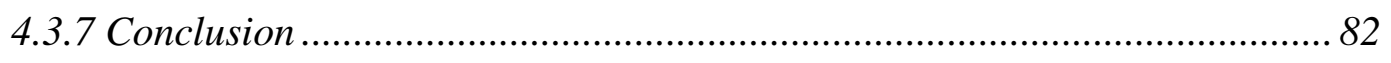

CHAPTER 5: DISCUSSION ....................................................................................84

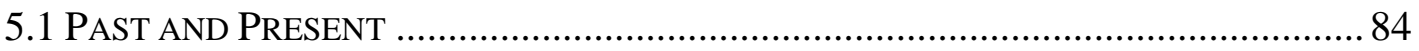

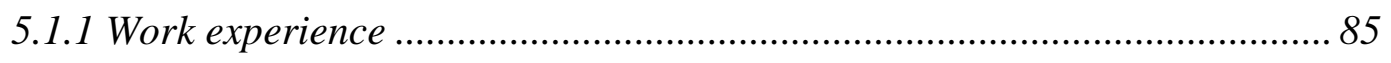

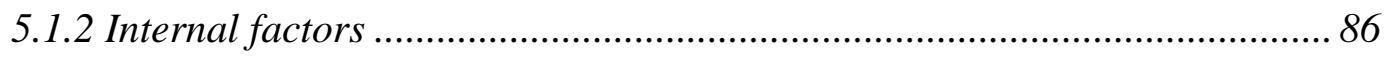

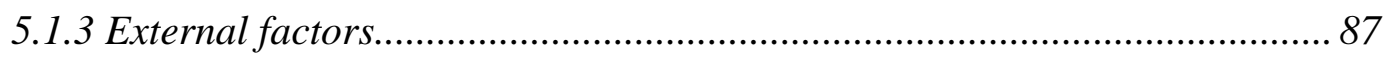

CHAPTER 6: CONCLUSION AND RECOMMENDATIONS .............................92

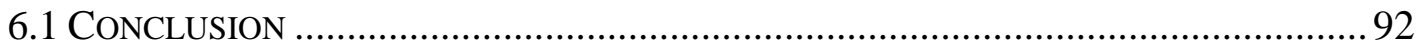

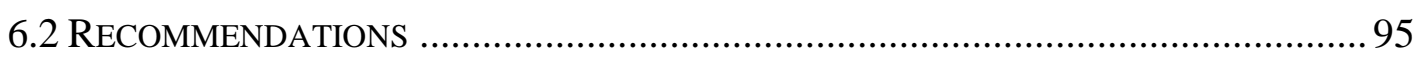

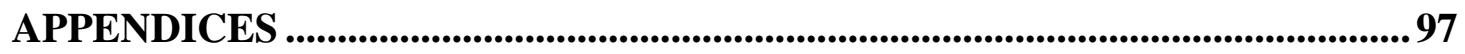

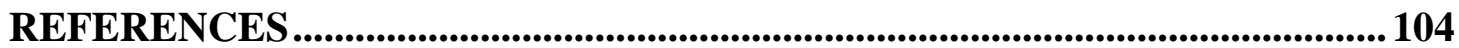




\section{List of Figures}

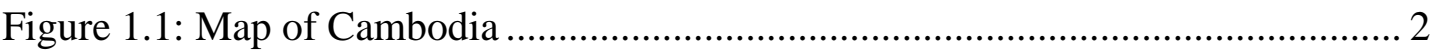

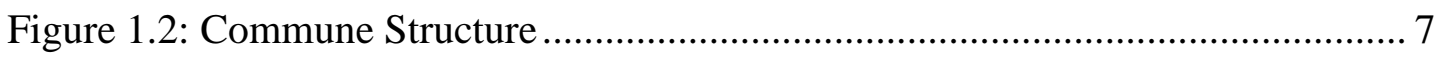

Figure 1.3: Villager Committee Structure ............................................................. 9

Figure 2.1: Internal and External Factors that Influence Women Leaders ................ 29

Figure 3.1: Cambodian Map showing case study provinces ................................... 32

Figure 5.1: Practical Leadership Pathways for Women in Cambodia ....................... 91

\section{List of Tables}

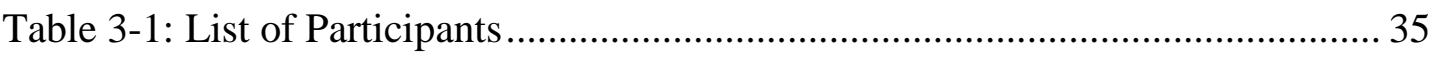

Table 4-1: Level of Education Women Local Leaders ............................................. 48

Table 4-2: Additional Income of Women Leaders in the Three Communes ............. 68 


\section{Acronyms}

\begin{tabular}{|c|c|}
\hline APP & Khmer Anti-Poverty Party \\
\hline CCWC & Commune Committees for Women and Children \\
\hline CPP & Cambodian People's Party \\
\hline CWCFP & Commune Women and Children Focal Point \\
\hline $\mathrm{D} \& \mathrm{D}$ & Decentralisation and Deconcentration \\
\hline DMP & Democratic Movement Party \\
\hline FCP (FUNCINPEC) & $\begin{array}{l}\text { French Acronym for United National Front for an Independent, } \\
\text { Neutral, Peaceful, and Cooperative Cambodia }\end{array}$ \\
\hline GADC & Gender and Development for Cambodia \\
\hline HRP & Human Rights Party \\
\hline KADOC & Khmer Association for Development of Countryside Cambodia \\
\hline KNP & Khmer National Party \\
\hline LAMC & $\begin{array}{l}\text { The Law on Administration and Management of } \\
\text { Communes/Sangkats }\end{array}$ \\
\hline LDP & League for Democracy Party \\
\hline NGO & Non-Government Organisation \\
\hline NRP & Norodom Ranaridh Party \\
\hline PYD & Paz Y Desarrollo (Peace and Development) \\
\hline RDP & Republic Democratic Party \\
\hline SRP & Sam Rainsy Party \\
\hline USAID & United States Agency For International Development \\
\hline VFP & Volunteers for Prosperity \\
\hline WCCC & Women and Children Consultative Committee \\
\hline
\end{tabular}





\section{Chapter 1: Introduction}

\subsection{Research Significance, Aims and Questions}

With the exception of a brief period in history, Cambodian women have occupied inferior positions in society. Nationally, only 20 per cent of women occupy top political positions, only 15 per cent of middle level managerial positions are held by women, and at the local levels, women account for just 18 per cent of local leadership (Sethi, 2013). Apart from these women, the majority of Cambodian women are engaged in informal and unpaid domestic work, making them financially dependent on men and at times subject to domestic violence and abuse.

Political and economic changes in the 1980s and 1990s, together with the subsequent government reforms from the 2000s onward, have resulted in slow improvements for women in Cambodian society and politics. Women are beginning to serve in top political positions at the national level, while there are more women entering local politics. The success of these women not only marks an achievement in national and international efforts to address gender inequality but also provides important insights into possible pathways for personal and professional development for other women in society. There has not been enough academic research to understand these achievements and pathways to leadership, particularly within the specific context of Cambodia.

Based on an in depth analysis of the experience of selected local women leaders, this thesis develops a practical leadership model that aims to increase women's participation in local politics in Cambodia. The model is able to provide an understanding of leadership pathways for Cambodian women who want to be local leaders in the future. The model is the result of a qualitative methodology and case study approach which has been applied to explore the complexity of leadership in Cambodia. Real-life situations of women local leaders in three communes in the North-Eastern provinces of Cambodia provide the information to support this model.

Developing a practical leadership model is one way of helping to increase women's participation in local politics. Craft (2012) asserts that the absence of role models prevents other women from getting further on in their careers. Therefore, in order to 
fill the gap between the absent leadership model and the need for more women to become local leaders, the study employed three main research questions to guide the inquiry:

(1) What type of work, characteristics, and resources influence women to become local leaders?

(2) What are the experiences that female local leaders have been through?

(3) What can be learned from women's backgrounds and experiences to assist in the formation of a practical leadership model to help guide other women aspiring to be local leaders?

These questions guided the data collection through to the analysis of the finding and the creation of the model. It is hoped that the findings will encourage women in leadership roles at the grassroots level, and that the model will be a useful guide for women to reach higher positions in their careers. As a consequence, they will then be able to participate in decision making and thus help to reduce the cycle of poverty in which most women are trapped.

\subsection{Context for the Study}

\section{Figure 1.1: Map of Cambodia}

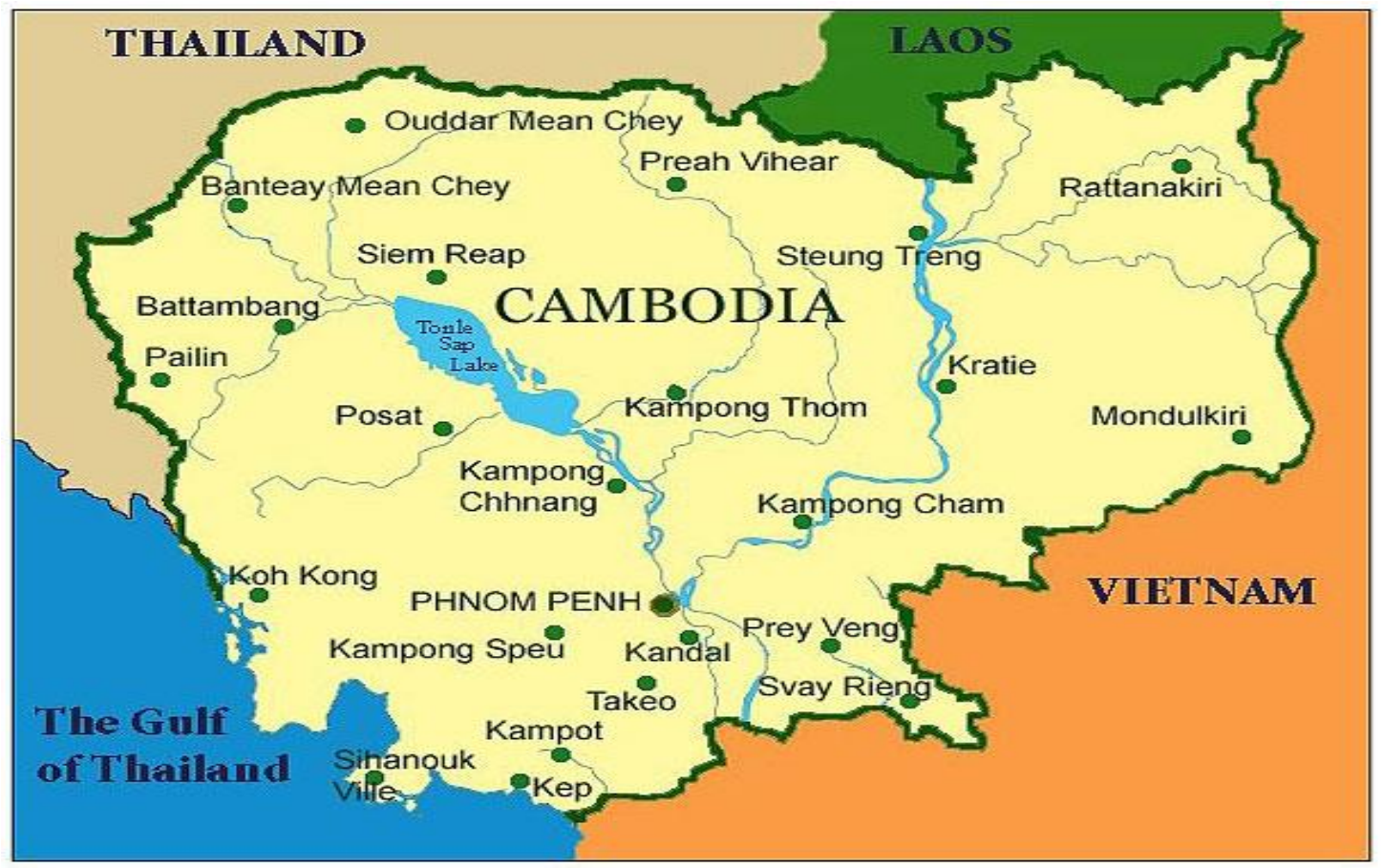

Copyright 2005 by CAMBODIAHOME.COM 
Cambodia has an interesting history of the role of women in politics and society. Historically in Cambodia women holding leadership positions have been rare, with the exception of a few royal queens. The involvement of these queens has had a strong influence in the leadership of the country (Nguon, 2000). Such leaders were Princess Liv Yi; Khmer Queen Jayadevy, the mother of King Jayavarman VII, Jayarajadevi and Indradevy (the two wives of Jayavarman VII), chief teacher for the King, Indradevy and the Queen Mother Sisowathe Kossomak Nearyrath (Chandler, 1991; Pym, 1968; Rooney, 1994 cited in Nguon, 2000). They were all knowledgeable and active in sectors such as the social, economic, political and cultural aspects of society.

Currently, Cambodia is a hierarchical society and there exists gender inequality in almost all sectors of society (Gorman, Pon, \& Sok, 1999). Based on data produced by the United Nations Development Programme (2011), the gender inequality index score in Cambodia is still a problem at about 0.5000. This is the lowest level in Asia. With a population of around 14.1 million, Cambodia is among the poorest countries in the world with 53 per cent of the population living on under USD2 per day (Bertelsmann Stiftung's Transformation Index, 2012; World Bank, 2012). A vast majority of the people ( 80 per cent) live in rural areas where they rely on subsistence farming for a living (National Institute of Statistics, 2011). The population consists of 51.1 per cent female and 48.9 per cent male (World Bank, 2012).

Based on the data, women comprise more than half of the human resources, so development goals cannot be reached without their involvement in the sustainable improvement of well-being in society (Reddock, 2000). Women leaders are necessary for the development of Cambodia and their involvement in leadership roles in the public sphere and politics is crucial and impacts on poverty reduction (Ministry of Women's Affairs, 2008). Lilja (2007) conducted interviews in 1996, 1999, 2002 and 2007 with some Cambodian women, who had local leadership positions. She found that those women were known to be compassionate and often understood people well as they took care of basic needs, domestic duties, education, and others (Lilja, 2007, 2008). In decision-making, more women and children's issues were raised and discussed by them.

The Constitution of the Kingdom of Cambodia in 1993 fully acknowledges the equal rights of women and men and protects women's interests in all activities. The Ministry of Women's Affairs (2009) has developed a Five Year Strategic Plan to build 
women's capacity to increase women's participation in decision making at all levels. These strategies were developed in three phases: the Neary Rattanak (Women are Precious Gems) Phase I (1999-2003), II (2004-2008) and III (2009-2013). Prak and Schuette (2007) report that these strategies aim to ensure gender responsiveness within national policies, legislation and reform programs. Kim and Öjendal (2012) state that the Government of Cambodia has also passed several laws including The Law on Administration and Management of Communes/Sangkats (LAMC), and the Law on Commune Elections in 2001. These two laws aim to define the democratic decentralisation system and to encourage democratic development in Cambodia. To begin with, in 2005 the government applied the Decentralisation and Deconcentration Reform and the Organic Law in 2008, in order to delegate functions and authority from the central to the sub-national level. One of the purposes of these reforms is to address gender equality in local politics (Kim \& Öjendal, 2012). As a result, women are perceived to have a better status today than in the past, and have a better opportunity to participate in leadership roles especially at local level (Griffith, 2010). In recent times, women are also working outside the home to get more income and are active in politics, culture, health, agriculture and industry.

Despite this, the implementation and effectiveness of Cambodian government, civil society and international agency projects on gender issues remains limited. Lack of representation is considered a key problem which leads to exclusion and disempowerment of women's interests (race, ethnicity, class, gender and sexuality). Without women's representation, women's issues may not be raised or discussed in order to find solutions for them. For instance, a lot of Cambodian women at the local level face sexual/physical/emotional abuse. Griffith (2010) shows some challenges that women face, such as cultural norms, attitudes, disparity in education, domestic responsibilities, child care, financial and family support, and negative perceptions of women.

The data from the Ministry of Women's Affairs (2008) shows the number of women holding positions at sub-national level: women held 11.8 per cent of deputy governors positions, 14.6 per cent of commune councillors, and 30 per cent of village committee members. These figures of women holding leadership positions at the local level are still way behind those for men. In the provinces it is worse, for instance, in the NorthEastern province of Cambodia, women leaders at the local level are rare (Prak \& 
Schuette, 2007). In 2012, based on data from the National Election Committee, the proportion of female candidates in the North-Eastern province was less than 30 per cent (National Election Committee, 2012). Due to this, three communes in three North-Eastern provinces including Kampong Cham, Kratie and Steung Treng were selected for the empirical base of this research. Previous studies and research (Kim \& Öjendal, 2012; Thon, Ou, Eng, \& Ly, 2009) show that some communes in these areas have active representation of only a few female commune chiefs, female commune councils and female village committees whom villagers consider as their local leaders.

\subsection{An Overview of Local Leadership Structures in Cambodia}

In 2002, the Royal Government of Cambodia began their political decentralisation by organizing the Commune/Sangkat elections for all communes. Usually, each commune consists of five to 11 councillors depending on their geographic and demographic profiles (Mansfield \& Macleod, 2004). For instance, if a commune has around 4500 people, then the commune committee consists of five councillors. If there are up to 8000 people in a commune, then it has seven councillors. The more population each commune has, the more councillors it has. The number depends on how the people vote. Under the Law on the Administration and Management of Communes, a member of a Commune/Sangkat council has to be re-elected every five years. This process is usually called a five-year mandate. The elections have occurred three times already, in the first mandate (2002-2006), the second mandate (20072012), and the third mandate (2013-2017).

Commune council elections are conducted using a proportional system of representation where seats are allocated based on the proportion of votes received by each of the political parties contesting the election. All commune council members are selected from political parties' candidate lists. The number of commune councillors in each commune is determined by subdecree. The commune council seats are allocated according to the results of the elections. Elections are conducted in communes that have more than one political party's candidate list approved for registration. All candidates are selected from a political party's candidate list in a sequence starting at the top of the list (Mansfield \& Macleod, 2004, p. 5).

In Cambodia, there were a number of political parties in the 2012 Commune/Sangkat elections such as the Cambodian People's Party (CPP), the Sam Rainsy Party (SRP), FUNCIPEC Party (FCP), the Norodom Ranaridh Party (NRP), the Human Rights Party (HRP), the League for Democracy Party (LDP), the Khmer Anti-Poverty Party 
(APP), the Khmer National Party (KNP), the Republic Democratic Party (RDP), and the Democratic Movement Party (DMP). The Cambodian People's Party is still the dominant party in Cambodia and has been since 1979. For the election process, each political party has to identify key people as their candidates to put on their party list. At the commune level, people in each party conduct the preliminary voting for 10 to 15 members including new and old candidates. Whoever gets the most votes will be named as the first candidate and those with fewer votes stand as second or third according to the number of votes. Then the list of initial voting will be brought up to a higher level (district and province) for discussion or the rearranging again of the order of the candidate list. After the final list is obtained, it is transferred to commune level for commune/Sangkat elections which happen every five years.

According to the Article 1 of the sub-decree on the decentralization of powers, roles and duties to commune/Sangkat councils, the elected Commune/Sangkat councils are accountable to all residents of their Commune/Sangkat (Royal Government of Cambodia, 2002). All residents, during working hours, also have the right to conduct their affairs with the Commune/Sangkat Councils; to be informed about the commune's work; to make suggestions and complaints. The Commune/Sangkat councillors consist of the Commune Chief, First Deputy Chief, Second Deputy Chief, and Members of the Commune Council (one of the members is the commune's gender focal person) as shown in Figure 1.2. Based on Article 19 of the sub-decree on the Decentralisation of Power, the roles and duties of commune/Sangkat councils are such that an appointed gender-focal person must be in charge of women's and children's affairs (Royal Government of Cambodia, 2002). A gender focal person is usually a woman and she advocates for women and children's issues, and contributes in the decision-making process in the commune meetings on how to improve basic living conditions and create awareness on the health care of women and children. Additionally, every Commune/Sangkat has a clerk who is appointed and employed by the Ministry of Interior to assist the commune's administrative work. 
Figure 1.2: Commune Structure (as cited in Thon et al., 2009, p.25)

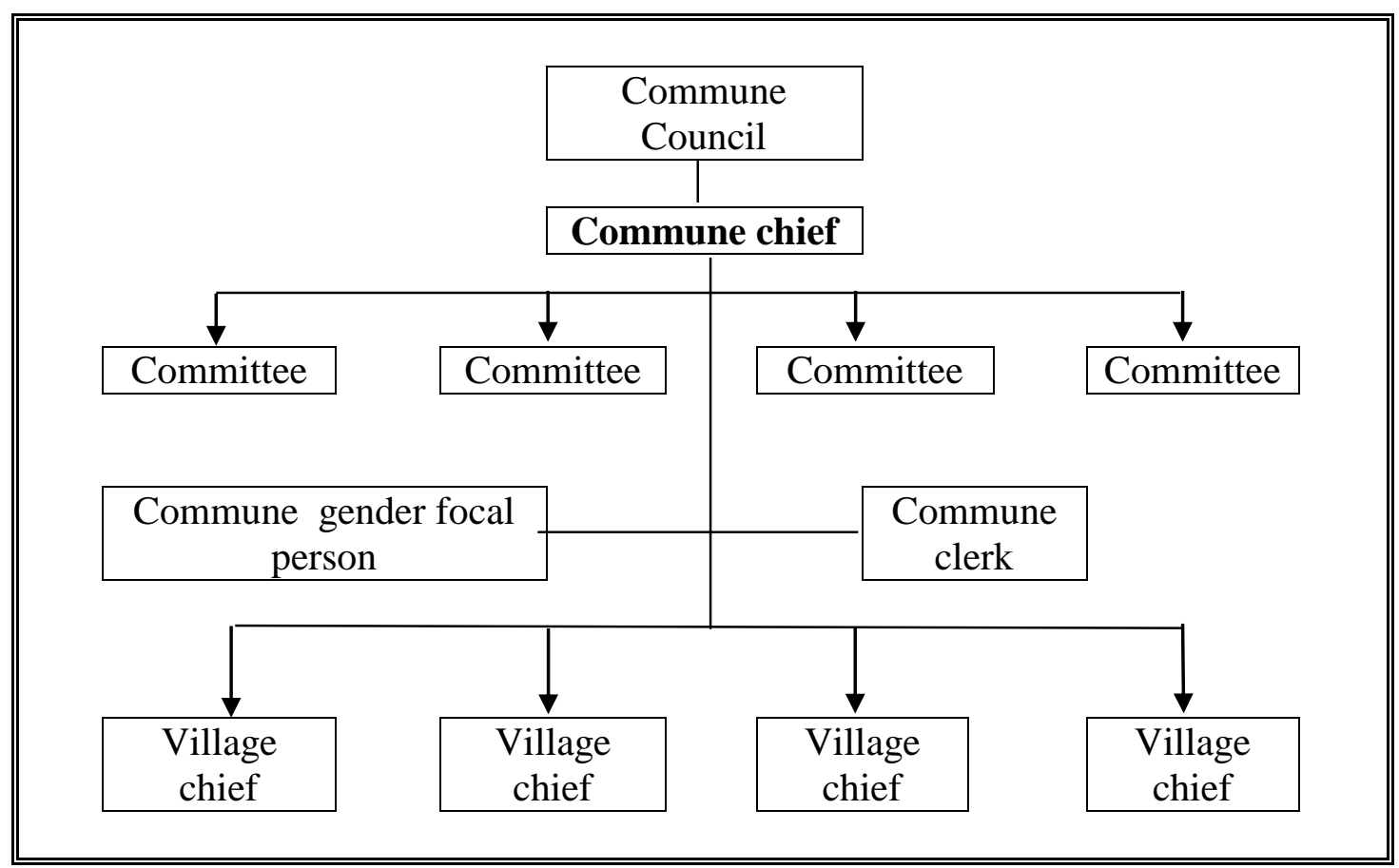

\subsubsection{Role and Structure of Commune Councils}

Based on the Article 20 of the sub-decree on Decentralisation of Powers, commune authorities have two types of roles: a key person in commune affairs and an agent of the central government authorities (Royal Government of Cambodia, 2002).

In the local commune affairs, Commune councils have specific duties as follow:

- The commune chief advises the councils on how to develop and mobilize the local capacity and resources, seeks partnerships and manages tasks relevant to development plans and budgets, and ensures all the implementation of decisions and policies.

- The first deputy commune chief assists the commune chief on economic and financial affairs.

- The second deputy commune chief helps the commune chief on administrative and social affairs, public services and public orders.

- Other commune members assist in tasks as assigned by the commune chief. Article 19 of the Sub-decree also states that a commune/Sangkat should appoint a woman councillor to look after women's and children's affairs. If 
there is no woman as a councillor, the councils assign a woman to be an assistant in charge of the women's and children's affairs.

Commune councils have duties to promote and maintain in areas such as agriculture, economics, public works, social order and security and women and children' issues. They have to ensure that all of their service delivery meets the basic needs of the commune. However, Commune councils have no authority in forestry, post and telecommunications, national defence, national security, monetary affairs, foreign policy, fiscal policy and other areas as stipulated by law (Royal Government of Cambodia, 2002).

By 2014, the monthly salary of commune councillors had increased three fold compared to 2008. Commune chiefs receive from USD25 to USD75. Both first and second deputy chiefs receive from USD20 to USD60. Commune committee members receive from USD17.50 to USD50. This, the monthly salary of commune councillors is not much when compared to their cost of living. Thus, most commune councillors find other additional sources of income to compensate for their low salaries.

\subsubsection{Role and Structure of Village Committees}

Each candidate is selected by the commune councils to assist the commune's work, and the village chief appoints a deputy chief and a village assistant as seen in Figure 1.3. The selection of village committees is not like the election of commune councillors. It is less complicated and more informal because the names of villagers and commune councillors are called out in the selection process which is held at the commune office. Among six candidates, whoever receives the most votes from villagers will become a village chief, and the second person will be a deputy chief, and the third person will be a village assistant. The result will be announced immediately after the selection process finishes. All elected candidates will become the village committee, which is the lowest grass-roots administrative authority of the government (Rusten, Kim, Eng, \& Pak, 2004). According to Article 22 of the subdecree on decentralization of powers, roles and duties assigned to commune/Sangkat councils, every village committee member must be a resident who lives in the village, and one of them must be a woman (Royal Government of Cambodia, 2002). As a result of this, 30 per cent of village committees members now are women (Ministry of Women's Affairs, 2008). 
Figure 1.3: Village Committee Structure

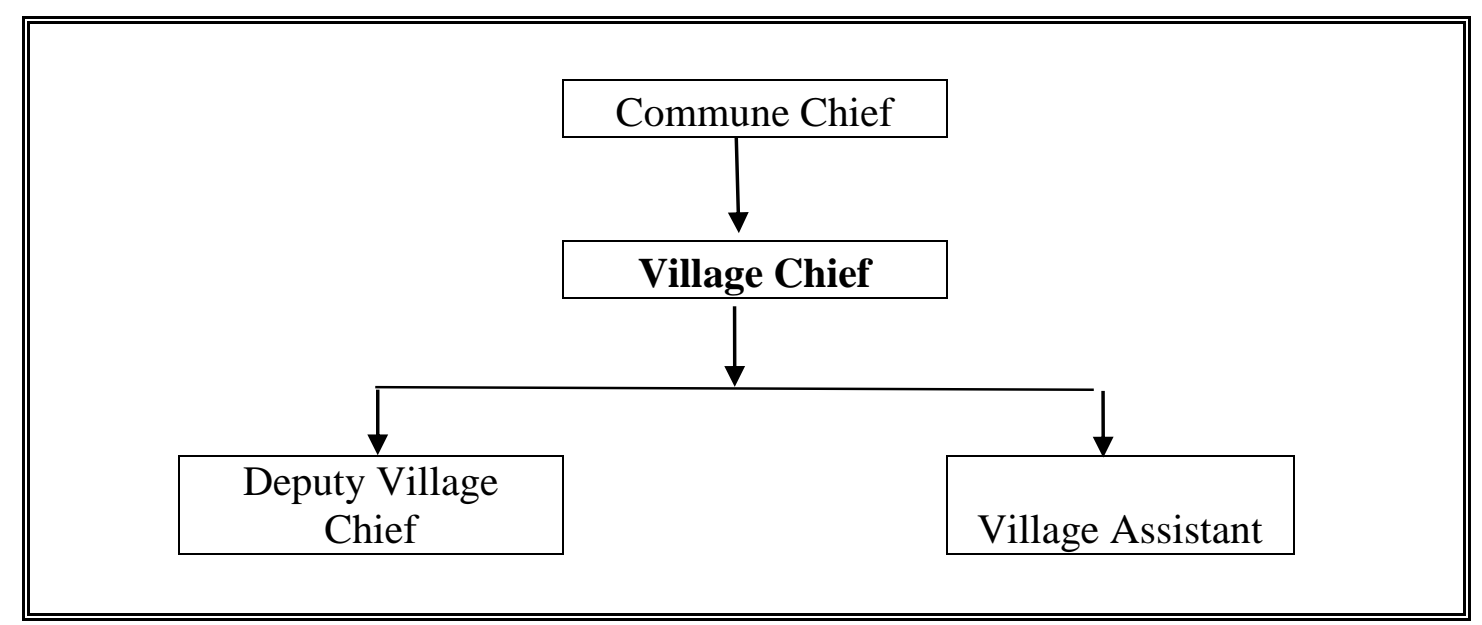

Based on the sub-decree of the Article 24 of the sub-decree on the decentralisation of powers, roles and duties assigned to commune/Sangkat councils, village chiefs have as their main duties the promotion of the consultation and cooperation within their Commune/Sangkat Council. This includes participating in meetings, mobilising people for meetings, maintaining social order, and advising the village advisory committee on how to develop and build the capacity of village resources. In addition, they are to advise the Government Development Plan and Budget Committee and to report matters relating to the village. Deputy village chiefs and village assistants have a role in helping the village chief's activities. They are a link between the village and the commune/Sangkat council. Village chiefs have no authority to sign contracts, to hold power or to arrange their own activities on behalf of their village. Village chiefs normally do not produce written reports; they can only make an oral report to the commune office. The monthly salary is USD30 for a village chief, USD25 for deputy village chief, and USD20 for village assistant.

This section has outlined the roles and responsibilities of each local leader from commune/Sangkat level to village level. It has also indicated the process of how each local leader accesses their formal positions via the five-year mandated election and the less formal village selection of their committees. Due to the government's decentralisation reforms, women seem to have a greater opportunity to get involved in local politics. At least one woman is present at the commune and village levels. It is believed that women' representatives at the local level will help leaders pay more attention to problems affecting their communities and other women's issues. 


\subsection{Research Approach}

For this research I employed a qualitative approach to answer the research questions. Case studies were conducted to explore the complexity of the real-life situation of Cambodian women in three communes of the North-Eastern provinces of Cambodian. Multiple research techniques were applied, such as key informant interviews, focus group discussions, participation observation, informal interviews, snowball sampling to obtain participants and analysis of archival records (detailed in Chapter 3).

Although I faced some challenges during the fieldwork, that delayed my arrangements and scheduling to meet with informants, I eventually gained valuable experience and information. In previous employment, I was a research assistant for five years and often worked and interviewed both male and female local leaders regarding local government issues. Thus, I understand the local context very well. During fieldwork, meeting with each informant was difficult because most of them were not present during office hours all the time. I had to find networks and contact numbers in order to reach informants. After I got their phone numbers, I arranged a certain time to meet them at their house or somewhere near their places. I knew how to get close to them and to build rich conversations. Moreover, finding accommodation at the local areas was difficult because there was no guest house available nearby the target areas. It took me several hours travelling to and from my accommodation in the main province to each remote commune each day. However, all meetings with participants were eventually organised and rich information gathered that related to the research topic because I understood the nature of local government processes from past experience with local people.

\subsubsection{Researcher Positionality}

I paid critical attention to positionality because it enabled me to engage with the research process in a more meaningful way (Sultana, 2007). Although I faced difficulties when some participants were reluctant to speak in the interviews because they thought I was a stranger from a city, I could still negotiate these tense situations because I positioned myself well. Being a researcher, in terms of positionality, I placed myself as both an insider and an outsider. Wright (2012) states that positionality is where researchers put themselves in the world of the participant and 
acknowledge people's emotions that come through things, histories, places and experiences. I know that I am not a part of the participants' communities, but I tried to build close relationships with them in order to gain their trust. I often visited their homes and I spoke to participants as if they were my family members, such as an aunt or uncle. I understand that the use of local language was important and could reduce the power gap between participants and myself. I also presented myself as a local student, and a young learner with whom people in rural areas can talk to and discuss issues. To gain their trust and to help the flow of conversation I shared my background with them.

\subsection{Relevance of this Study to Development Studies}

Gender analysis has been part of development discourse for some time now (Jackson \& Pearson, 1998), although in the past gender and development studies often did not discuss gender differences as an issue which blocked economic growth (Willis, 2005). Women were often excluded and left on the margins of capitalist development. Women were associated with the domestic and reproductive areas, while men were not held responsible for household chores. Due to this, women were often unable to benefit from any development. In the 1970s, the Women in Development (WID) approach was introduced. This resulted in women having a greater degree of participation in development. For instance, the United Nations said in 1975-85 that development that excluded women was not real development because it did not address the issue of gender inequality and the disadvantages that women faced when lacking the opportunity in decision making that affected their lives (Willis, 2005). Since then there has been an on-going debate about the development process that shows a lot of unequal power relations between men and women in every part of society. It is because inequality prevents equitable and sustainable development (Gorman et al., 1999). Parpart (2008) noted that women's empowerment is a key and very important goal for development institutions such as the World Bank, United Nations Development Programme (UNDP), Oxfam and other smaller NGOs. Empowerment is a weapon for the weak that ensures their real participation at the grassroots level (Parpart, 2008). Ban Ki-Moon, Secretary-General of the United Nations, states that the Millennium Development Goals (MDGs) has as its central 
principle to end extreme poverty from the world by valuing human dignity, equality, and equality between men and women across the globe (United Nations, 2014).

In Cambodia, social-economic change has linked the country's own development to the world, but the country still faces hunger and social issues, especially gender inequality. This means that Cambodian development moves very slowly. Only a few Cambodian women are in decision-making positions or have real power. Women face more constraints in this society than men. Gender disparity exists in every sector of society. Thus, the Millennium Development Goals for Cambodia aim to reduce significant gender disparity in upper secondary and tertiary education, in employment in all economic sections, in public institutions, and to do away with all forms of violence against women and children (Ministry of Planning, 2010).

NGOs and international donors also play valuable roles in mainstreaming gender. Currently there are many Cambodian and international NGOs which focus on women and gender's issues (Ministry of Women's Affairs, 2004, 2008).

The Royal Government of Cambodia, as well as donors, are increasingly recognizing the importance of addressing gender issues in poverty reduction strategies and development goals in order to promote sustainable development for women and for the whole population. Gender disparities in access to and control of a wide range of human, economic and social resources and opportunities must be eliminated if Cambodia is to reduce poverty (UNIFEM, WB, ADB, UNDP, \& DFID/UK, 2004, p. iii).

The significance of this study is that it hopes to contribute to the debates surrounding policy and practice change in attempts to address gender inequality by sharing the findings with government and NGOs. More women leaders are needed. It is hoped that women can be empowered to transform society and make it better. Helping to improve the lives of women at the grass roots level where their voices can be heard through their own leadership style, is important for women to advance.

\subsection{Thesis Structure}

This thesis is organized as follows: The introduction provides the research significance, aims and questions; context for the study; an overview of local leadership structure in Cambodia; research approach; relevance of this study to development studies; and thesis structure. Chapter 2 discusses the theoretical background to leadership and provides a conceptual framework about leadership. It 
has three main themes: type of work, personal characteristics and the resources which have an influence on women as local leaders. The methodology is explained in Chapter 3, and Chapter 4 covers important findings of the study by looking at what factors encourage women to become local leaders based on the three main themes. Chapter 5 synthesizes the findings to derive a general pattern of a leadership pathway that could bring Cambodian women to significant positions in local politics. Finally, Chapter 6 concludes this study and provides some recommendations for those involved in improving women's leadership participation in society. 


\section{Chapter 2: Theoretical Background}

In the literature on leadership, gender and development has emerged as an important issue in both the developed and developing worlds (Willis, 2005). Lack of women's representation at the grassroots level is an issue which affects vulnerable groups such as women and children. This is why governments, donors and NGOs put in extra effort to balance the inequality through strategies and programmes. However, there are still debates on how to develop a meaningful and effective tool for enhancing gender equity in a complex world because women's empowerment is still questioned (Parpart, 2008). There is still no obvious leadership pathway for Cambodian local women who want to step into local leadership arenas. Therefore, this chapter seeks to develop a conceptual framework for providing a guide to explore how some women local leaders succeed in taking leadership roles. This chapter explores how the success of these women may become a model pattern for other women.

This chapter is divided into five sections. The first section looks at the concept of leadership. The second discusses the concept of gender and leadership. The next section finds out how women all over the world become leaders. The following section looks at leaders in the Cambodian context. The fifth and final section explains the conceptual framework for this study.

\subsection{Concept of Leadership}

Leadership is defined differently by different authors in terms of context and experiences. Giammatteo (1981) define leadership as the activity that helps people to reach a common objective or purpose. Leadership includes the ability to influence others or to mobilize people (Antonakis, Cianciolo, \& Sternberg, 2004; Johnson, 2009; Sweetman, 2000). Eagly and Carli (2007, p.8) define the term leader as "a person who exercises authority over other people". In addition, leadership has been thought of as individual traits, leader behaviour, patterns of interaction, role relationships, relations with followers, and follower perceptions (Duerst-Lahti \& Kelly, 1995; McCauley, 2004) . An understanding of the concept of leadership as involving both leaders and followers serves as an important reminder that the performance and success of leaders does not depend solely on the leader themselves, 
but also on the followers' attitudes, perceptions, relationships, and patterns of interaction with the leaders. Thus, a comprehensive study of leadership qualities must consider the followers and the common social, political, and cultural perception of leaders, especially where an issue such as gender difference might play an important role.

\subsection{Gender and Leadership}

Leadership is traditionally thought of as being associated with men in most societies. Men have been considered as powerful, having authority and knowledge. Eagly and Carli (2007) state that men find their way to leadership more directly than women whose way to leadership is more akin to a labyrinth. In the study of women in leadership, the concept of labyrinth has been used in various places including ancient Greece, India, Nepal, North and South America, and medieval Europe (Eagly \& Carli, 2007). Globally, opportunities for women in leadership roles are not equal because their paths to reach these goals involve many barriers (Kellerman \& Rhode, 2007). Those barriers include traditional stereotyping (employment discrimination), lack of support networks, and work-family conflicts. Although some women can find their way to become leaders, the direct and indirect ways of getting there are subtle and difficult to discover.

According to Duerst-Lahti and Kelly (1995), few women can reach top management or leadership positions because they face a "glass ceiling". The term "glass ceiling" was introduced in 1987 as a metaphor for women's inability to break into executive offices. For example, in the United States' political environment, women experienced sexual harassment by offensive men, which often created a barrier for women to be leaders (Duerst-Lahti \& Kelly, 1995). Jamieson (1995) considers "the glass ceiling” as the double bind that constrains women's ability to achieve their leadership goals. She states that the double bind concept comes from some high profile female leaders' experiences, such as Flo Kennedy and Kathleen Hall. The double bind means, first, that if women "act like a man" they will be thought of as an aggressive person, and secondly, if they "act like ladies" they will be considered ineffective. Consequently, they are caught in the bind. To illustrate this point, Eagly and Carli (2007) raised an example of Hillary Clinton during her presidential campaign when she was criticized for being too cold. Yet on camera she showed up as emotionally weak. She was 
intrigued at being critiqued for being both. Therefore, although some women succeed in their leadership roles, people still think that they are weak to some extent because they are caught in a double bind of being women who have to act like men.

Even if women are considered weak, effectiveness is still debatable because leadership ability is based on an individual's ability and not on gender.

If leadership effectiveness is dependent on an individual's interactive style and their ability to adapt to certain situations, gender should not be such an issue. Instead, society has made it a barrier for women and has encouraged people to question women's credibility when there is no need for such (Craft, 2012, p.8).

For instance, great women have played leadership roles in their respective societies from mothers to warrior queens (Klenke, 1996). For instance, Mary Robinson, Elizabeth I, and Mother Teresa, were active in social movements, helping a nation and community work respectively. They could identify problems and help people who were weak in their societies, even though they were women. They became a role model for other women due to their ability and achievements. Chapman (1993) states that when women participate in social politics they can make a change in the governmental structures that usually favour only men. The literature agrees that it is important to understand how women have managed to succeed in patriarchal societies.

\subsection{How Women all Over the World Become Leaders}

Based on her interviews with hundreds of women, including Hillary Clinton and Kathleen Hall, about who can beat the double bind, Jamieson (1995) points out that these women can break the double bind from all walks of life in five ways. First, women should access education and use it as a tool to increase their knowledge. This gives them more choices. Sweetman (2000) adds that education can also build women's capacity to be independent, develop critical thinking, and foster selfconfidence. Second, women have to learn the art of public speaking, and be able to access other sources for help. Thirdly, women should think and act equally. Women should give themselves the right to equality with men by not putting themselves down. Next, women have to be willing to reconcile contradictory expectations. They have to be a flexible person. Lastly, women have to think that they can still be a leader later in life as leadership is not just for the young (Jamieson, 1995). 
Jamieson's points are important for this study, and can be summarized as suggesting that the key factors for women to successfully get into leadership positions is for them to have a good education base, have the ability to communicate to the public effectively, and to be seen as a moderating force in the existing gender divide. The third part indicates that women should show their fairness and act equally among both sexes. In addition, women should know how to get rid of a tense situation by creating a cooperative and peaceful atmosphere. Lastly, women should keep their dream to be leaders without thinking about the passing of time and their age. It can never be too late for women to be leaders.

In addition, to loosening the double bind in some circumstances, women must overcome these challenges through changing social attitudes. American women have shown their societies that they are not weak, but that they are good at leadership roles, and people start to like their leadership styles. Sharing the life experiences of a number of famous women (Anna Mulcahy, CEO of Xerox; Hillary Clinton; Executive Sawn Steel and more) in the American business industry and political arenas, Eagly and Carli (2007) state that people place more value on women's leadership due to their leadership style. The way of leading by some American female leaders is more encouraging and rewarding to their followers (Eagly \& Carli, 2007). They can often work smoothly with both men and women because they are warm and friendly leaders. They are often less intense and more balanced than men. Because of this, Eagly and Carli (2007) claim that some people who worked with female leaders in their study changed their old perceptions in resisting women in leadership roles when they discovered that the female style was different but no less effective. Many people in America believe that women in leadership has become more fashionable since 1998 (Eagly \& Carli, 2007).

Kim and Öjendal (2011) state that economic and social factors within Cambodia have also changed ideas about women in leadership. Women are important in improving good government. According to a research in 2003, McGrew, Frieson, and Chan (2004) used semi-structured interviews and focus group discussions with nearly 60 people. These included many Cambodian women in politics and some men in four provinces outside of the capital city. One of their findings stated that the recognition of the value of gender equality is widespread in society and people are also aware of women's rights and support their political participation (McGrew et al., 2004). Kim 
and Öjendal (2011) claim that female commune committee members were given more opportunity due to their critical role in leading social affairs and commune's work, whereas previously women were given less value and were absent even in these areas.

The expectation in Cambodian society that women be kept in their traditional roles (women are associated with domestic responsibilities) may not be an obstacle for women anymore (Kim \& Öjendal, 2011). Some women in mainland China, Hong Kong, and the United States can manage their leadership roles successfully because they have both physical and emotional support from husbands, household help, and other family members to deal with household responsibilities including cleaning, cooking, laundry, shopping and caring for children (Halpern \& Cheung, 2008). Jensen (2008) states that family members (father, husband, or brother) of women leaders in the U.S., Ireland, and Sri Lanka play an important role in helping them to develop the self-esteem which is necessary to pursue their dream as leaders in public office. Margaret Thatcher, a former Prime Minister of the United Kingdom, laid out two main conditions for a women to pursue a successful career and run a home; Jensen summarized Thatcher's words (2008, p. 111):

First, her husband must be in sympathy with her wish to do another job. Secondly, where there is a young family, the joint incomes of husband and wife must be sufficient to employ a first-class nanny-housekeeper to look after things in the wife's absence.

Beyond the support from their husband or partners to share household chores and childcare, Eagly and Carli (2007) believe that women can become leaders by challenging two key doubts in order to walk through the labyrinth. Women must convince others by showing their competency and create social capital. In order to show competency, women should show men that they are equal to them. They can do this by being well prepared for their jobs and performing beyond expectations. This is hard for women, but women need to be exceptionally good and deliver more successful outputs than people expect. They have to impress people over and over again. This can be done not only by working on their own, but also by working cooperatively with followers.

Furthermore, creating social capital means that they have to be smart and good at creating networks with both men and women both inside and outside any organisation (Eagly \& Carli, 2007). They should be able to create positive relationships with powerful people and also with more-powerful associates. Women should also open 
doors for themselves and provide themselves opportunities to have more multiple tasks. These tasks will create superior feelings of well-being or confidence. Having a job is better than not having one (Eagly \& Carli, 2007). Women should balance their employment and family responsibilities. Appelbaum, Audet, and Miller (2003) also give similar examples based on their research in North American corporate society that women's leadership effectiveness in their organizations should include getting inside the Old Boys' networks. This is because men in the North American corporate society are seen as having the power to make an impact on women's careers. Women should seek help from the male networks who are their friends or co-workers. They should also make more of the Old Girls' networks.

Coleman (2011) supports the above aspects of networking and personal agency. Based on his research objective concerning the career challenges women face and how they overcame them, Coleman conducted interviews with 60 successful women (most of them married or having a child or children) holding leadership and management positions in the United Kingdom and elsewhere. His findings state that hard work, persistence, ambition, proactiveness, determination, drive, confidence, singlemindedness, and a positive mindset are the main success factors. These findings were found from investigating in detail the challenges the 60 women faced, the choices they made regarding having children, and the changes they have seen and expect to see. $\mathrm{He}$ also believes that family support plays a significant role in pushing women forward into leadership.

Apart from the above aspects, women also need financial support to make their leadership dreams happen, especially in the political sector. Hoare and Gell (2009) identified in their case studies (in the Philippines, Israel, and the UK) that women cannot participate in leadership roles unless there is enough financial support to place them in all aspects of government structures. In South Africa and Norway, women parliamentarians in both countries have a similar aim: to introduce gender budgeting. They want state spending analysed in order to allocate resources to women' needs such as child-care services, to extend parental leave, and to introduce flexible working hours (Hoare \& Gell, 2009). Importantly, they would like governments to create quota laws that can regulate the selection of women to political office. Hoare \& Gell (2009) state that over 40 countries have adopted quota laws to increase women's participation in politics. The governments of Sierra Leone, Haiti, and Honduras have spent much 
energy on electoral reform processes that are on-going long-term programmes to increase the role of women. The implementation of these programmes is to lobby for quotas and the reservation of seats for women. These programmes will help educate women voters about legislative changes and encourage them about their right to participate in elections.

Another way to increase the chances of success for women leaders is for women leaders to be democratically orientated in their style. Tracing the contemporary theories on transformation and transactional leadership styles, Jogulu and Wood (2006) contend that women seem to follow a more democratic, participative, and collaborative leadership style than the traditional male model which is quite hierarchical. Jogulu and Wood (2006) discuss theories from the works of Burns (1978) and Klenke (1993). Burns (1978) stated that two very different types of leadership are "transactional" and "transformation" leadership. The transactional type was associated with masculine qualities which show hierarchical authority, whereas the transformation type is the feminine model of leadership that identifies potential in their followers. This second model builds upon collaboration and less control (Klenke, 1993). Women have less masculine ways of leading. For instance, they often act as "a good-coach or good-teacher rather than a traditional command-and-control boss" (Eagly \& Carli, 2007, p. 119). An example is of a successful woman leader in an Australian company is Janet Holmes à Court, who turned the hierarchical pyramid of leading upside down by encouraging and empowering people to reach their dream (Eagly \& Carli, 2007). She used a 'bottom up approach' to work with people. She encouraged her staff and gave them opportunities to step up to a higher position. Her leadership style is more collaboration rather than domination.

In addition to the democratic style discussed above, in a work environment, Giammatteo (1981) theorises that in leadership roles, both women and men must have some skills in order to become leaders. First, in their personal behaviour they need to be sensitive to the feelings of the group. This means refraining from criticizing, arguing or ridiculing others' suggestions. People who demonstrate these skills help others to feel important and needed. Secondly, communication skills mean that a person can make sure that everyone understands not only what is needed but why. Thirdly, skills in equality mean that s/he prefers sharing rather than exercising a monopoly. Next, organizational skills allow leaders to help people with group 
planning, acting, following up and evaluation. Lastly, self-examination skills help leaders to become aware of their own forces, attitudes and values.

The concept of leadership involves both leaders and followers. Their relationships are set and connected, based on the context. Many men are usually dominant in the leadership sphere, but some women also reach that stage. Before women can achieve their leadership roles, they face many challenges. As stressed above in the literature, pathways to becoming a leader involve two big spheres. These spheres show the division of inside factors (leaders' attitudes and behaviour) and outside factors (pattern of interaction and followers' perceptions). These two factors are the main framework for understanding women in leadership roles. All aspects mentioned show that women leaders can influence hierarchical structures in society, and can change their way of life to some extent, if they have an education, the ability to communicate with others, the opportunity, and family support. Practically, they can reach the leadership stage by working collaboratively with others and by balancing family-work relations. Additionally, women can demonstrate their behaviour by being friendly, kind and helpful in order to get through the labyrinth.

\subsection{Leaders in the Cambodian Context}

\subsubsection{Who Are Considered Local Leaders in Cambodia?}

The commune and the village have been considered as the local communities in Cambodian society from the pre- and post- Civil War era (Thon et al., 2009). The local communities have local leaders who are the closest people to the villagers and they have the ability to organise communities with regard to particular issues. This contrasts with the district chiefs who are considered outsiders or lokthum (big person) (Ledgerwood \& Vijghen, 2002). According to Ledgerwood \&Vijghen (2002), there are different types of leaders who have a strong influence on, or power in, local areas. They divide these local leaders into six categories:

1. Administrative domain: administrative officials or official leaders such as sub-district level or commune councillors and village chiefs.

2. Religious domain: those mostly involved in religious sphere; they can be laymen, nuns, monks and local pagoda committee members. 
3. Knowledge domain: those who are educated and have positions as health workers and teachers.

4. Spiritual domain: traditional healers.

5. Economic-political domain: rich and powerful persons; they are the most important persons in the village.

6. Development assistance domain: workers or NGO activists and foreign personnel.

These six types of local leaders have different levels of power in different contexts and situations. This study selected only administrative leaders at commune and village level, mainly women leaders, for further exploration. The local government officials sit at the lowest grades and also receive the lowest pay among other government workers (The World Bank, 2005). According to an article in the Cambodia Daily newspaper, although the local government officials received their doubled salaries by the sub-decree released on August 31, 2013 they said that the pay was still not enough for them and their family to live comfortably (Khy \& Henderson, 2013).

\subsubsection{Women Leaders in the Cambodian Context}

Past and present literature seems to provide a varied and incomplete picture of how women become leaders in Cambodia. Internal and external factors exist and are discussed here. For example, in the past, Ebihara (1968) has mentioned that morality, in general, was a component of village leadership. Collins (1998) also added that a reputation for moral integrity and a degree of humility were important for effective leadership (cited in Ledgerwood \& Vijghen, 2002). Ebihara (1968) found that in the 1950s-1960s the selection of Cambodian local leaders was based on literacy, competence, good character, relative wealth and willingness to work with less pay. Sin (1995) examined the historical networking of Cambodian women and leadership. She stated that some Cambodian women succeeded in occupying a high political position due to their loyalty to the political party, having courage, determination, and past experiences in social struggles. Women became leaders by networking with top male leaders, so women politicians needed to learn "the political ropes" through building close mentorships and cooperation with male political workers (Sin, 1995).

\footnotetext{
${ }^{1}$ The political ropes refer to political ties that affiliate women to a particular political party. For example, a woman can become a member in a party by someone who works there recommended for her. Then, she can seek support from the connection.
} 
Today, some of these above mentioned attributes are still important. For instance, Sin (1995) has suggested that a strong personal drive is a key in overcoming challenges that women face such as physical, environmental, psychological and financial barriers. Nguon (2000) pointed out that education has a key role to play in the multidisciplinary efforts of women. She claims that education can bypass the barriers of socio-cultural difference and low self-confidence. Thus, education opportunities for women and girls are essential. According to the work of the Asia Foundation which has placed 325 female commune councillors in 13 provinces for the past few decades, their main aim is to help women to reach their full potential and make a positive change in Cambodia (The Asia Foundation, 2013). From their experiences, they have found that education for girls helps to increase productivity, provides better health outcomes for women and their families, enriches greater environmental awareness and increases the participation of women in public life.

When women have an education they can move themselves up in leadership and be recognized in public affairs and have a strong voice in dealing with social issues. So, development, gender equity and peace development can move faster. Similarly, Lilja (2006) explored how politically engaged Cambodian women reacted against the male domination of democratic arenas. She carried out interviews with 69 Cambodian women who had been involved in politics at both the grassroots level (governors, heads of communes, villages, etc.) and the national levels (members of the Parliament or the Senate). She stated that women must be recognized as knowledgeable leaders in order to gain legitimacy and power to become local political actors. Hence, knowledgeable women leaders with confidence can impress men.

Understanding villagers' attitudes toward leaders is also important. One of the main notes from the National Conference on Women Moving toward Progress on 6-8 September 2011, stated that leadership does not rely only on the capacity of an individual, but that the talent and charisma of that person are also factors (Silaka, 2011). The charisma means the skills, behaviours and relationship of a leader to followers, which make followers like the way they act or lead. However, Devarachetty (2012) states that women have rarely been called charismatic leaders because of some societies' bias against women. As Devarachetty says, there is still no literature stating clearly what kind of leadership style Cambodian people in rural areas would like to see from their leaders. A survey of roughly 15 per cent of villagers in three communes 
on leadership done by Thon et al. (2009), states that villagers' attitudes towards leaders are based on various perceptions depending on economic, social status, education and ethnicity.

Apart from knowing villagers' attitudes, Ledgerwood and Vijghen (2002) claim that kinship and patronage are still at the heart of Cambodian social organization. Therefore, networking and patron-client relations are important factors that enable Cambodian women to be involved in politics and build their leadership identity (Lilja, 2006). Networking has different forms. Women can network abroad, within the village, with other women, among female politicians, within political parties, or the family (Lilja, 2006, 2008). Two examples of patron-client relations and family connection are provided below.

First, one of the 69 women that Lilja (2006) interviewed revealed that a woman commune leader gained her political career at a commune level because of patronclient relationships. She gained support from villagers due to the fact that they used to get help from her parents, so they supported her in return.

I had a better reputation (than the other candidates). Besides my education, my parents used to help everyone, and those people remembered my parents. When my parents weren't alive anymore they supported the children instead (cited in Lilja, 2006, p. 10).

Secondly, close family connections, and a family-orientation are the key political networks of many women in Cambodia. For instance, husbands often help wives to gain advantages in terms of positions (Lilja, 2006). With the aim to increase women's participation in local politics, a similar case study was investigated in the North East of Cambodia where a number of women were holding leadership positions such as commune chief, village chiefs and committee members (Maffii, 2011). The study claimed that the women leaders' families and husbands in some communes in Kratie province had agreed to help those women leaders with household chores (cooking and washing) and so leave their wives free to travel and be active in their political roles (Maffii, 2011). This action indicates a remarkable change and is considered indicative of men's new roles in Cambodia. This action is the opposite of the traditional code of conduct for women 'Chbap Srey' ${ }^{2}$ which states that they should be subordinate to their husbands and be responsible for all housework.

\footnotetext{
${ }^{2}$ Chbap means law and Srey means women. Chbap Srey was a kind of Cambodian traditional melody called "Phouchhong Leelia". It was written in the nineteenth century for guiding the daughters and
} 
The women's movement in Cambodia has shown that a lack of economic independence is no longer an obstacle for women's participation in the public sphere (Prak \& Schuette, 2007). Women play an important role in household food security. Their incomes are mainly from the agricultural and informal sector (commercial activities). The garment industry also provides a source of income for many women. Lilja (2006) argues that many women seem to contribute more than their husbands to the household budget. Cambodian women are very active in micro, small and medium businesses (Ministry of Women's Affairs, 2004). Women also contribute more than half of the household income to ensure nutritional standards for family members (International Fund for Agricultural Development of the United Nations, 2003). More than half (53 per cent) of women are economically active compared to men where only 32 per cent are active (USAID, 2006, p. 6). They work in many tasks - as agricultural labourers, waged employment and taking care of household tasks. Thus, they are not totally reliant on their men's income.

Because of changing social movements, Cambodian women also have more chance to get involved in politics. Historically, men were dominant in the political sphere and only a few women were involved. However, Kim and Öjendal (2012) state that in a post-conflict country like Cambodia which has been influenced by Western principles of democracy since 1993, things are different. Gender equality has been introduced by international NGOs and donor agencies to help women out of the traditional domestic trap. They want to see a better political situation for women where they can share their views and make decisions which affects their lives. Thus, these policies and practices have made a change in the rural political arena. For instance, the Decentralisation and Deconcentration (D\&D) process has transformed society since 2005 to a certain extent, giving women more space to become local leaders. The D\&D reform is the devolution of power to elected local councils and the decentralisation of power and function from central to local governments in Cambodia (Rusten et al., 2004). In 2001 Cambodia created two laws, the law on the Administration and Management of Communes (LAMC) and the Law on Commune Elections (Thon et al., 2009). Since then, the country has held the commune/Sangkat elections in 2002, 2007, and 2013. The change is to ensure democracy in Cambodia and to ensure that women take part in local politics.

wives in the Cambodian society (Kraynanski, 2007). The Chbap Srey was published into book format and taught in school. 
Recently, Kim and Öjendal (2011) have found that the success of women in leadership does not only depend on individual personality, a smart mind, popularity, bravery, a high level of education, networking and commitment. They state that female leadership is also derived from the new situation created by the Decentralisation and Deconcentration reform as well as NGO activism on gender equality, socioeconomic transformation, and the timeliness of any leadership attempt. "Women are seemingly most successful in generating popular support in their private capacity, and are partly aided by public policies and laws" (Kim \& Öjendal, 2011, p.21).

Thus, the traditional societal norms are no longer an obstacle for women. The United Nations Development Programme (2011) reports that the government has also established quotas for women in the institutional structures such as in the Deputy Governor, Village Administration, Women and Children Consultative Committee (WCCC), Commune Committees for Women and Children (CCWC), and Commune Women and Children Focal Point (CWCFP). Deputy Governor and WCCC are at the national level, while WCCC, CCWC, CWCFP and Village Administration are at the sub-national level. These positions are responsible for providing advice and recommendations to relevant people or groups on issues related to gender equality, women, youth and children within the authority, functions and duties of the local commune. Decentralization and local and commune elections have given rural women a chance to enter local government and participate in decision-making which has had an impact on the welfare of their communities (Menh, 2009).

Due to these changes, women can become leaders when the time seems right (Kim \& Öjendal, 2011). However, Kim and Öjendal recently contended that in the commune/Sangkat elections, political parties are the key determining force in forming gendered local political representation (ibid, 2014). Communes/Sangkats play an important role at the grassroots level because they have the main power as they are close to villagers. Communes and Sangkats are the government's sub national level and under direct control of the province, cities, and the capital. Officials of the subnational level are the network and the representative of political parties and they can help their parties to win both local and national elections. "When a political party can take the people's votes at this level, it could win the local elections for five-year-term" (Women's Media Centre of Cambodia, 2012, p. 5). 
The party system in Cambodia uses the straight party-list PR (proportional representation) system and this demands closer links between voters and their elected representative (Reilly, 2007). Political parties usually appoint their candidates and define their candidate lists. Then the voters choose the parties. The nominated candidates of the chosen parties then ascend to political positions (Kim \& Öjendal, 2014). Winning candidates are derived from party lists. Thus, political parties are the gatekeepers in local politics deciding which women can or cannot be leaders despite their efforts. "The party system constitutes a conservative block of patriarchal resistance to greater gender equality" (Kim \& Öjendal, 2014, p. 23).

Therefore, women suggest a quota system or more regulations in promoting women in each political party under the policy framework for gender equality. This is because women candidates are often put at a lower level in the party lists, making it hard for them to be elected as local leaders. Although women are often not elected, some women still become commune council chiefs due to their past working experience and their popularity at the local level. These women understand their local context and know how to deal with local issues. Some elected local women used to work as volunteers in the village, so they are well known and people, the voters in the village, are likely to choose these women as their leaders. Kim and Öjendal (2014) suggest that voter pressure will make a change which will make public demand for more women to be in higher positions on the party lists.

All in all, the literature seems to favour factors such as morality, reputation, literacy, competency, relative wealth, and loyalty as the internal strengths that local leaders should have. Current literature seems to focus more on personal drive, the government's reforms, NGOs activities, family support and the political party's support, as the driving factors for increasing female local leaders. Women face various barriers such as a traditional social-cultural mind set (patriarchal society), weak support from a party, no real support from policy implementers, a low education, low self-confidence, poor household economy and personal security when carrying out work at night (Kim \& Öjendal, 2011; Lilja, 2007). All of these can hinder their opportunities for leadership. 


\subsection{Conceptual Framework}

This research, located in the Cambodian context, synthesizes three main themes that have been found to have an influence on women taking leadership roles. The three main themes are 'type of work' (developed from Kim \& Öjendal, 2012; Ledgerwood \& Vijghen, 2002), personal 'characteristics' and 'resources' (derived from the authors mentioned in the previous sections such as Ebihara, 1968; Sin, 1995; Lilja, 2006, SILAKA, 2011; Ledgerwood \& Vijghen, 2002; Mafii, 2011; and Kim \& Öjendal 2011). Figure 2.1 provides a framework using each of these themes. The type of work here focuses on the past working experience that led the women in the study to become local leaders at the village level or the commune level. This work allows them to work as local leaders in different ways including as commune leaders (such as commune chief or councillors) and village leaders (chief or members). Next, the personal characteristics (the internal factors) focus on education, good character, and personal drive. Lastly, the resources (the external factors) will be divided into government reforms, NGO activities, family and people support, and political ropes (party connections).

The review of the literature in this chapter has identified some similar key internal and external factors that are thought to enable women to become leaders. They discuss the education and characteristics of female leaders and their ability to communicate with others, whereas the opportunity, family and outsider support are also important. Nevertheless, none of this literature provides a comprehensive model that shows a way to help women to take roles in leading their communities. They all favour their individual arguments and discuss different spheres regarding their individual social contexts. Thus, in this study I have combined each of their significant findings and have developed a pre-assumption framework for leadership for women in Cambodia, as shown in Figure 2.1.

This conceptual framework as a synthesis of past research provides a guide for exploring the reality of how some women local leaders succeed in taking up their leadership roles. This study takes this framework but tests it and adapts it to the current context. The next chapter will discuss my methodology for testing this model against the actual lived experience of women leaders in the North-Eastern province of Cambodia. 
Figure 2.1: Internal and External Factors that Influence Women Leaders

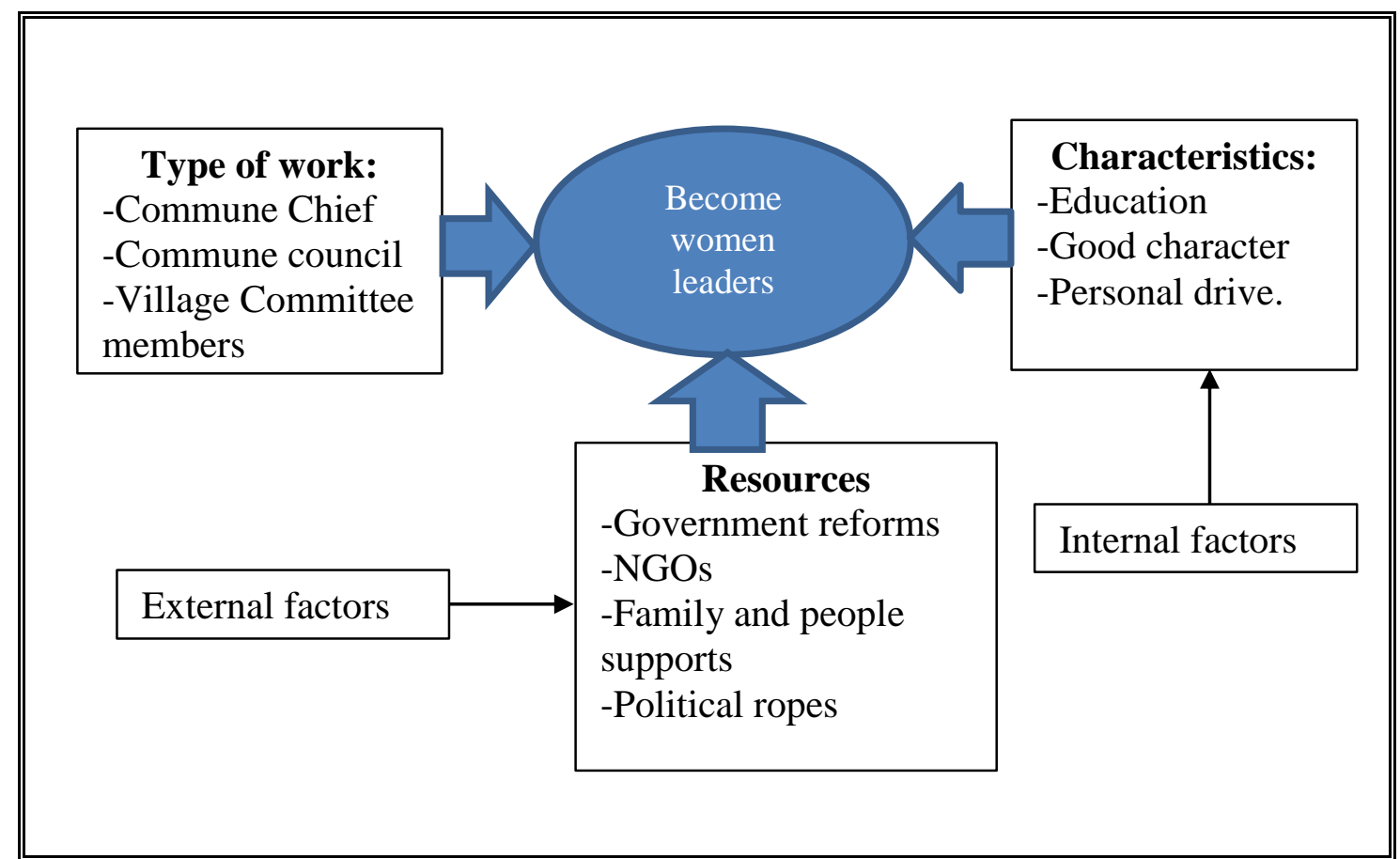

Sources: (Ebihara, 1968; Kim \& Öjendal, 2011, 2012; Ledgerwood \& Vijghen, 2002; Lilja, 2006; Maffii, 2011; Silaka, 2011; Sin, 1995)

This conceptual framework as a synthesis of past research provides a guide for exploring the reality of how some women local leaders succeed in taking up their leadership roles. This study takes this framework but tests it and adapts it to the current context. The next chapter will discuss my methodology for testing this model against the actual lived experience of women leaders in the North-Eastern province of Cambodia. 


\section{Chapter 3: Methodology}

\subsection{Introduction}

This study employed a qualitative methodology because it provides the best way to answer research questions that are keen on exploring what research participants think and feel. The methods used helped to answer the research questions. Mikkelsen (2005) states that qualitative research can enable researchers and participants to have direct conversations in which together they can share information, knowledge, experience and expertise. A case study design was also used as part of this qualitative approach because I wanted to understand the complexity of real-life situations (life experiences, behaviours, and emotions) of how women become leaders at local levels in Cambodia. Denzin and Lincoln (2005) claim that case studies can provide accurate information regarding society, politics, cultures, and the economy of a particular society. Qualitative research is time-consuming and relies on a relatively small number of participants, but it can tackle sensitive issues, bring into focus the broader social context of people's experience and can connect different areas of people's lives (Griffin, 2004). This chapter is divided into eight sections, namely, explanation of the case study approach, case study sites, methods used for data collection, reflections on the field research, data analysis, ethical issues, and the scope and limitation of the study.

\subsection{Case Study}

By design, the case study method usually answers questions of "how and why" and the method adds or extends experiences to what is already known in the past. Case studies explore real life situations by using multiple sources of evidence (Lapan, Quartaroli, \& Riemer, 2012; Soy, 1997). Each real-life case contributes to the whole study. For this reason, the method is likely to be able to provide answers to the main research question of this study: how women become local leaders in Cambodia.

According toYin (2003) the case study approach is divided into three steps: design, multiple-case data collection, and cases analysis and interpretation. From the literature review I designed a theoretical framework regarding leadership (Figure 2.1). This 
framework navigated the study by identifying and setting boundaries and developing research questions, but the framework was eventualy redefined based on my research findings. Criteria were identified for the selection of each case study and various methods were employed for data collection. The analysis, synthesis and interpretation of the data was compared with the existing literature to produce results which are unique and different from others as discussed in Chapter 5.

\subsection{Case Study Sites}

Fieldwork was conducted in three communes in the North-Eastern provinces of Kampong Cham, Kratie and Steung Treng (Figure 3.1). The three communes are labelled differently to ensure participant confidentiality, namely, KP, KO, KS. The rationale for the selection of these communes is based on three reasons:

1. An understanding of the local leadership context of these communes and research experiences are already known from previous studies (Kim \& Öjendal, 2012; Thon et al., 2009).

2. The interested communes have some active representation, including a female commune chief, female commune councillors and female village committee members.

3. Women leaders at the local level in the North-Eastern province of Cambodia are rare. This means that they are worthy of investigation and observation (Prak \& Schuette, 2007). 
Figure 3.1: Cambodian Map showing case study provinces (Target provinces are located by a star shape)

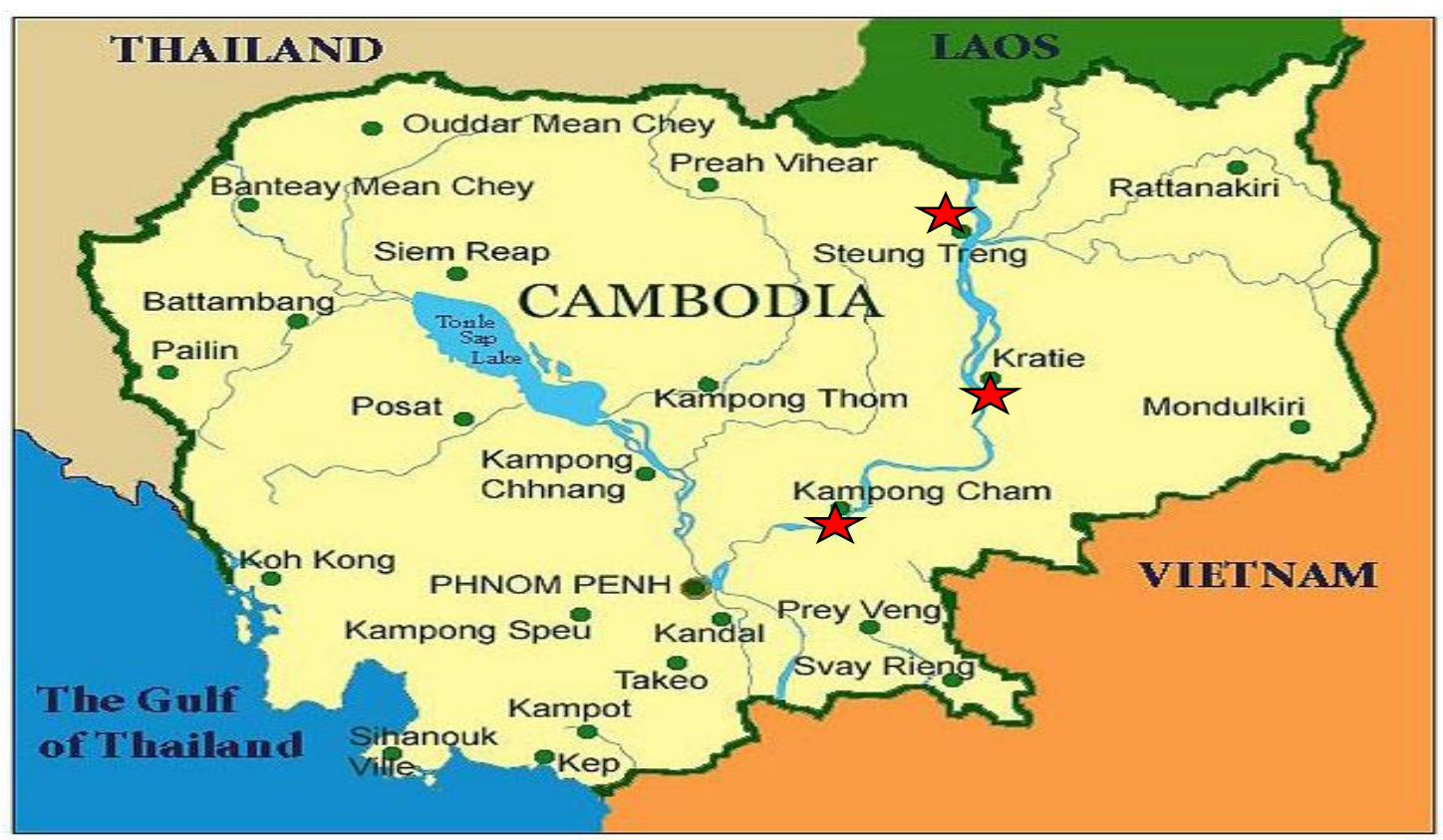

Copyright 2005 by CAMBODIAHOME.COM

\subsection{Methods}

For the data collection, multiple techniques were applied to select participants and record their perspectives. These include key informant interviews, focus group discussions, participant observation, informal interviews, together with a selection process of snowballing and documentation and analysis of archival records.

Key informant interviews are valuable in getting information, knowledge, and experiences of participants in a particular context and highlighting real social, cultural, political and economic issues (Bryman, 2008). They gave me a deeper understanding of how women local leaders are affected by internal and external factors.

Focus group discussions help researchers to select a topic to discuss in a group of people in order to analyse it in detail (Acocella, 2011). Participants can interact with each other and the discussion can provide different views and understandings that are new to both researchers and participants (Cameron, 2005). Then, the practice of sharing knowledge among group discussions will be produced regarding place, relationships, processes and events that participants can contribute to. I noticed that participants did not just agree with each other at some points when I applied this 
method but they also questioned one another, which helped to draw out a range of views and understandings.

Participant observation was employed because it can help to portray how affected people are involved and deal with their problems (Dingwall, 1997). I had an opportunity to participate in several informal group meetings in some villages. The meetings provided me with good information about the relations between villagers and women local leaders and their personal lives. However, participant observation is time-consuming and researchers face difficulty with documenting information (Cargan, 2007). For instance, I could not write down everything that was important because I had to rely on my memory to write it down and try to observe everything that was going on. Memory can easily and quickly fade away. Sometimes, informal interviews were also conducted when I was carrying out observations to clarify my doubts. Importantly, home visits with some key informants were taken to observe their activities.

To select participants, a snowball strategy was used to obtain key informants and people for group discussions (Cargan, 2007). This strategy helped me to identify people with a similar trait or interests. For instance, women local leaders, male commune councillors, villagers and other actors were all told and targeted as important actors in this study. Nevertheless, this method is quite subjective because it nominates people known only by participants, so it presents only part of a group of people (Bryman, 2008).

I documented and analysed archival records and collected them at the same time as the field research interviews. Archival records included commune and village profiles, the history of the commune structure, networks and information about people. These helped me set each case study into its own unique context. Together, these methods, interviews, focus groups and field observations gave me plenty of data for each case study.

\subsubsection{Protocols and the Fieldwork Process}

Various protocols and procedures were also created in advance before heading to the field. Both informal and formal words in the design of the questions and letters of approval (appointment arrangements) were carefully used to ensure cultural 
appropriateness and understanding. Additionally, being a good listener who can pay attention to record the exact words from interviewees was practised. All fieldwork was carried out from May to July, 2014. The fieldwork was divided into two phases and in Table 3.1, the list of participants is given.

Phase 1. In-depth interviews with a number of female commune chiefs, female commune councillors, and female village committee members were conducted. Aiming to collect comprehensive and systematic data, the research interviewed three women leaders in each commune. The interview questions are in Appendix 1. Bryman (2008) notes that the interview questions should encompass the opening question, the main questions, sub-questions, structuring questions, silence, explanatory questions and interpreting questions (cited in Chum, 2010). Each question was broad and openended to encourage interviewees to articulate their ideas in their own words in order to gain their insights (Bryman, 2008). Structured observation was applied while doing the interview or when there was a commune meeting held by women local leaders. The duration of each interview was approximately one hour. The interview was recorded or noted and took place in the interviewee's house or at commune offices. A repeat interview was conducted with the same participants to verify facts.

Phase 2. Focus group discussions can facilitate interaction among participants and maximise the collection of high quality information in the time allowed (Acocella, 2011). Two group discussions were conducted in each commune in which mainly villagers and male councillors were interviewed. The division between villagers and male councillors was to avoid any power dominance that may cause inhibition and discourage conversations. This is because if participants feel equal, they will express their ideas more spontaneously (Acocella, 2011). These discussions also enabled cross-checks and increased the validity and trustworthiness of key informants' answers. Some key family members and neighbours were also interviewed when the discussion found that they had same influence on the women leaders. The duration of each focus group interview was around one hour and I used a tape recorder and made field notes. 
Table 3-1: List of Participants

\begin{tabular}{|l|l|c|c|c|c|c|}
\hline No. & $\begin{array}{c}\text { Type of } \\
\text { participant }\end{array}$ & $\begin{array}{c}\text { Commune } \\
\text { KP }\end{array}$ & $\begin{array}{c}\text { Commune } \\
\text { KO }\end{array}$ & $\begin{array}{c}\text { Commune } \\
\text { KS }\end{array}$ & Total & $\begin{array}{c}\text { Time for the } \\
\text { interviews } \\
\text { (Hours) }\end{array}$ \\
\hline 1 & $\begin{array}{l}\text { Female } \\
\text { commune } \\
\text { chief }\end{array}$ & 1 & 1 & 1 & 3 & $3 \mathrm{~h}$ \\
\hline 2 & $\begin{array}{l}\text { Female } \\
\text { commune } \\
\text { councillor }\end{array}$ & 1 & 1 & 1 & 3 & $3 \mathrm{~h}$ \\
\hline 3 & $\begin{array}{l}\text { Female village } \\
\text { committee } \\
\text { member }\end{array}$ & 1 & 1 & 1 & 3 & $3 \mathrm{~h}$ \\
\hline 4 & $\begin{array}{l}\text { Focus group } \\
\text { discussion 1 } \\
\text { (3-4 male } \\
\text { councillors) }\end{array}$ & 1 & 1 & 1 & 3 & $3 \mathrm{~h}$ \\
\hline 5 & $\begin{array}{l}\text { Focus group } \\
\text { discussion 2 } \\
\text { (key family } \\
\text { members, } \\
\text { neighbours or } \\
\text { other } \\
\text { villagers): } 5-7 \\
\text { people }\end{array}$ & 1 & 1 & 1 & 3 & $3 \mathrm{~h}$ \\
\hline
\end{tabular}

\subsection{Reflections from the field research}

Positionality is where researchers put themselves in the world of the participant and acknowledge people's emotions that come through things, histories, places and experiences (Wright, 2012). I, as an outsider, who lives in the city, tried to place myself in the local context by acting as an insider. Because I used to work as a research assistant who was experienced in this type of fieldwork, I knew how to speak and dress locally. I changed the way I spoke by using local words or slang. I called participants "aunt", "uncle" and "sister" because this informal language helped me build a close relationship with them and share stories and knowledge (Nagar \& Raju, 2003). I changed the way I dressed because people who live in the city are dressed differently from rural people. I presented myself as a local student or a young learner with whom villagers could talk or discuss some issues. I spent several days visiting participants at their houses and offices in order to gain their trust. I shared with them my personal story and I was also asked many questions about my study life and family 
background. Consequently, I gained their trust and so I had fruitful discussions with them.

Regarding reflexivity, my research was influenced by Sultana (2007). She notes that "reflexivity in research involves reflection on self, process and presentation, and critically examining power relations and politics in the research process, and researcher accountability in data collection and interpretation" (Sultana, 2007, p. 376). Kobayashi (2003) also states that researchers should insert themselves into a grid of power relations which help them to interpret the knowledge. I asked myself a lot of questions in order to uncover things and important information that I sometimes took for granted when I placed myself as an insider. Each day after I finished my observation and interviewing, I usually spent an hour reading my notes again and thinking about why things happened in this or that way. I kept to myself in silence for a while, then I asked myself why women who become leaders do so in spite of the challenges they face. What would I do, if I were in their place? What is the main reason behind their progress? At first I did not have a clear picture, but due to my reflections I investigated further and developed better questions. Thus, in consequent interviews I asked the women local leaders more probing questions.

Sultana (2007) also states that understanding power relations in the field will definitely help researchers to address or negotiate any difficulty that research participants naturally have with expressing their thoughts. Based on my research experience, Cambodia is a hierarchical society, so I had to show respect when I conducted a conversation with participants. I accepted my junior position as a student and as a young women. I paid my respect to them and was a good listener. Especially when I interviewed male participants, I felt that I should speak nicely to them and act politely. This is because in Cambodian culture women cannot act equally to men. Domosh (2003) states that there is no equality among participants and researchers, so there were two levels of inequality. In another situation, I found that participants thought of me as an educated woman who lives in the city. They assumed I knew more than them and so they spoke less. I tried to negotiate around this situation and let them share their experiences. Therefore, the concepts of positionality, reflexivity, and power were crucial for me to do my fieldwork because they helped to place me as both an insider and outsider in order to critically evaluate myself and the information that I was collecting and the process of fieldwork. 


\subsection{Data Analysis}

The data analysis and interpretation involved a process of summarizing and translating into English the audio-tape and field notes, classifying or coding the data, identifying connections and then describing any emerging patterns in these connections (Dey, 1993). Before reaching conclusions, data was cross-checked in different ways such as creating flow charts, tabulation of frequency of events, sorting, and categorising. A newly developed model was finally established. The final stage compared this model of the mechanisms by which women can become leaders to that derived from existing literature as illustrated in the previous chapter (Eisenhardt, 1989).

\subsection{Ethical issues}

Because this study collected primary data, many ethical issues were taken into consideration. These ethical issues are based on the three key principles of ethics by the Belmont Report in 1979, namely, beneficence, respect and justice (Mertens, 2012). The summary of the three principles is that the outcome of the research should have a positive impact on, and no harm to, participants who have been treated with respect.

The Victoria University Human Ethics Committee (HEC) ${ }^{3}$ approved my ethical application and the participant consent forms were applied in the fieldwork (Appendix 3). In the field, I introduced myself and explained clearly the purpose of the research and how the information would be used (Participant information sheets are in Appendix 3). Quotations from participants are used throughout the paper, so their names have been changed and codes are used to protect identities. The names of three communes have been labelled to ensure participant confidentiality. Respectfulness and good listening were employed, given the valuable time of interviewees. In addition, interviewees were informed of their right to withdraw from the interview process at any time and could refuse to answer any of the interview questions.

\subsection{Scope and Limitation of the Study}

Findings of this study will be indicative rather than representative because it was only conducted in three communes as per the case study approach. Also, the interviews

\footnotetext{
${ }^{3}$ Ethics Approval: 20850 (Appendix 2)
} 
with key informants and some villagers might not cover all aspects of leadership issues for women in Cambodia. For instance, the relationship between women leaders at the commune and women leaders at district or provincial levels are also important. The study sample is small, but it provides a snapshot of life for rural women seeking and experiencing leadership. This study could also specifically help the women who are interested in participating in leading the target communes or villages where the fieldwork took place because those places still lack women leaders.

Moreover, the limitation of financial support and time was a challenge. During the interviews, some new research problems were raised. For instance, women local leaders face some challenges in dealing with local infrastructural development, and they lacked the financial support to help them become successful local leaders. These problems are beyond this research study and they require further research questions and different research methods for gathering information or data.

\subsection{Conclusion}

This research study needed an appropriate methodology to answer the inquiry. This study took a qualitative methodology as a mean to find answers for the three main research questions. This was to explore the real life situations of some women local leaders in three communes. First, three communes were targeted as case studies based on the reasons of the selection communes. Lists of research questions were developed. Then, some data gathering techniques were conducted in the three areas including key informant interview, focus group discussion, participant observation, informal interviews, snowball sampling technique and documentation and analysis of archival records. All these methods were used both in phase I and II of the fieldwork process. During the interviews with participants, both researcher and interviewee were able to discuss, share and exchange knowledge with each other. Some aspects regarding data analysis have not been fully detailed here because this study has its limitations due to its scope. Therefore, what is of importance is what I could experience as an independent researcher and this research methodology helped me to navigate my own boat while I also learned about research along the way. 


\section{Chapter 4: Findings}

I think there are internal and external factors that help women to become local leaders. The internal factors: First women should be brave. Secondly, they should be patient. Thirdly, women should know how to read and write. The external factors are: Women should build their popularity with villagers and they should be helpful and willing to help villagers. They know how to help villagers in terms of ideas and sometimes they can provide rice, clothes or other stuff to the vulnerable groups. I think that is all the reasons that can help women to become local leaders. (A male second deputy commune chief, KS commune, Steung Treng province, 19 May 2014).

This chapter reports on findings from my analysis of the real life experiences of women local leaders in three communes. From the literature review, there are three main themes under which the women's experiences fall. They are the type of work, personal characteristics and resources. These three themes are the keys that help to answer the three main research questions of this study. 1. What type of work, personal characteristics, and resources influence women to become local leaders? 2. What are the experiences that female local leaders have been through? 3. What can be learned from women's backgrounds and experiences in order to assist in the formation of a practical leadership model to help guide other women aspiring to be local leaders? This chapter is divided into three sections corresponding to these research questions: (i) type of work; (ii) personal characteristics; and (iii) resources.

\subsection{Type of Work (Past Experience)}

Women leaders can be a village assistant, a deputy chief of a village, a female commune councillor (gender focal person) or a female commune chief at the local level. Knowing about the type of working experience that each woman leader has is one of the important parts of this research because it will show how the past life of each woman leader paved her way to leadership. This section is divided into three parts according to the three types of women local leaders: the female village leaders, female commune councillor and the female commune chief. Eight out of nine participants from the three communes, both in the communes and villages, claimed that past working experience had helped them to reach their current leadership positions, hence the focus here. 


\subsubsection{Female Village Leaders}

Information from the field interviews and observations from three communes (KS, $\mathrm{KO}$ and KP) showed that the previous work experience of female leaders gave them a chance to get involved in serving their villages. Not every woman can easily become a member of the village committees. It helps if she lives in a particular place and has some previous experience to ensure that she can perform the tasks given her in the village. Villagers also like a village leader who has had experience working with them.

From the first commune, a female deputy chief of a village in Steung Treng province said:

I have just started with the position since last month. I decided to work for the position because previously I was also a village assistant and villagers knew me and they like me, so they voted for me. (A female deputy chief of a village, KS commune, Steung Treng province, 14 May 2014).

In the second commune, a similar finding in the Kratie province showed that a woman became a village assistant because she had had working experience with an Orphanage NGO in a local village. She taught orphans about morality and hygiene. She stated:

I have started as a village assistant in the second mandate, while I was also a staff for an Orphanage NGOs. (A female village assistant, KO commune, Kratie province, 26 May 2014).

In regards to the NGO experience, a male commune councillor supported the subdecree stating that village leaders must be a citizen of the village because he or she should have a working relationship with villagers. When a woman has some work experience whether with the community or NGOs, she will be targeted for selection as a leader.

I think a person who wants to be a leader she must have lived in the commune or village since she was young and have experience participating in commune/village activities. If she is from a new place, people here will not support her. Moreover, that woman should have built her working experience with NGOs, for instance, PYD, whose project work closely with villagers. If a woman does not have the working experience, villagers and people in the party will not select her as a leader. (A male first deputy commune chief, focus group discussion, KS commune, Steung Treng, 19 May 2014). 
In the third commune, a female village assistant worked as a volunteer worker before she gained a role at the village level. She had working experience with villagers.

Before becoming a village assistant, I was a volunteer worker in a village. I educated villagers about birth control information. (A female village assistant, KP commune, Kampong Cham province, 10 June 2014).

All in all, three key female informants from different communes indicated that before moving to work in the village, they all had some relevant work experiences in the village context. The first women as village assistants, the next women with local NGOs, and the last one as an extension worker. They had all interacted with villagers and villagers knew them already. Thus, learning from their experience, women can become village leaders if they achieve relevant work experience which proves that they have the ability to accomplish the village's tasks and have a good reason to be chosen by others (villagers and commune councillors).

\subsubsection{Female Commune Councillors}

Women's work experience is also important for the selection of female commune councillors. These women have knowledge about women and children's basic health care or they are thought to have enough capacity to handle some of the commune's work. The field research information revealed that two female commune councillors claimed that one was previously a volunteer worker in a village and another one was a village assistant and worked with some local NGOs before they could fully be entitled to become commune councillors. A female councillor in Steung Treng province was able to become a commune councillor without having previous work experience. She became a leader due to another factor which will be described in section 4.3.6.

All three female commune councillors from the three different communes are now responsible for women's and children's affairs in the commune. They are called the Commune Gender Focal Person. It was hard to find a woman or a committee member who is currently the first or second deputy commune chief, which is a limitation of this research. Yet, these women were considered by villagers as one of the female leaders in the local context. Therefore, based on their past work experience they were selected and their experience is shared in the following section. 


\section{KP Commune}

A female commune councillor in KP commune shared her working story that she used to be a village volunteer and she had some knowledge about health care relevant to women and children. She knew people's problems and how to take care of them before she reached her present position. As a result of this experience, she was able to become a leader.

I have started with the job in the third mandate. Before that I was a volunteer in a village. I educated women and children about health care. As I remember I often helped poor people who did not know how to cure their diseases. I helped and guided them on how to access to health care at the provincial hospital or the hospital in Phnom Penh city, so people in the village knew me and they voted for me. (A female commune councillor, KP commune, Kampong Cham province, 9 June 2014).

\section{KO Commune}

Work experience is also crucial in this commune. The female commune councillor described briefly her work experience that she used to be a village assistant and worked with some NGOs. Thus, those NGOs have enriched her experience on how to interact and help villagers.

After the war, I was a farmer and a housewife. In 2002, I was a village assistant and worked in partnership with some NGOs who aimed to help my village. After that I have become a commune councillor since 2002. (A female commune councillor, KO commune, Kratie province, 23 May 2014).

\section{KS Commune}

Nevertheless, the third response of a female commune councillor in KS commune described that even though she had never experienced working in a village or elsewhere, she still could work for the commune because she believed that the commune's work was manageable compared to her ability.

I have been working as commune councillors since 2007. Previously, I did not work for anybody, I was just a villager and after I stopped studying, I stayed at home. After a while, I decided on my own to get involved in commune's works. At first I did not know how to do the job, but I wanted to test my ability. Then, when I could do the job and I started to like it. (A female commune councillor, KS commune, Steung Treng province, 13 May 2014). 
If women want to become female commune councillors, it seems from the evidence that they should work as volunteers at the village, as a first step to building their working background and to be known by villagers and others. In addition, it is useful to have some experience with administrative work. From the findings, almost all respondents said that past work experience is vital for women to prepare themselves before becoming female commune councillors, except in one case where the past work experience was not relevant.

\subsubsection{Female Commune Chiefs}

The interviews revealed that work experience, relevant to the local context, was also the foundation of each female commune chief. Both political parties and villagers preferred a person who had had work experience. From the three female commune chiefs of the three different communes, one used to work with a local NGO, one used to work at a district office, and the last one had been working with the commune for a long time and had moved up from one position to another position.

\section{KP Commune}

The female respondent shared her previous experience that the political party is likely to choose a person who has work experience to stand as their candidate. She said that women will have more chance of being approached to be leaders, if they have past eligible experiences.

I was elected as a Commune chief in the third mandate. Previously, between 1985 and 1990, I worked with Youth Association at the district. Then, I got married and stopped working for a while because I had to raise my children. However, in the third mandate, people at the district came and persuaded me to be their candidate for the commune/Sangkat election. They had asked me for many times, and then I decided to stand as their candidate. (A female Commune Chief, KP commune, Kampong Cham province, 06 June 2014).

\section{KO Commune}

Again, the female commune chief in KO commune has built her working experience with a NGO. The NGO trained her how to work with villagers and to help them. Thus, she knew her local context. Relying on her working experience, her political party was interested in her and chose her as their candidate, and so she could become a leader. 
I have been working since 2007, in the second mandate. Before becoming a Commune chief, I was a farmer. Then I worked for VFP NGO. The NGO works with vulnerable people and its aim is to fight corruption. During that time I also worked with a woman who is now a commune councillor. We both worked for the NGO and we advocated land law and other information to villagers. We received trainings and also provided what we had learned to villagers. From that experience with the NGO, my party has elected me to be a leader in the commune. (A female commune chief, KO commune, Kratie province, 21 May 2014).

\section{KS Commune}

A female commune chief in KS commune revealed her career ladder and described the reason she was elected as a leader. She worked from a small position to higher positions. She first worked as a commune councillor, then the first deputy commune chief, and lastly a commune chief. She knew work experience was important for her be able to move from a low position to another position. She had worked in the commune for many years, so her experience was very rich. It is the reason why her villagers liked her. Past work experience is the driving force for this woman leader. Without it she was unlikely to be approached by the political party or be elected by villagers.

I was elected as a candidate on the top of the party list. They selected me based on my past working experience. In the first mandate I was a commune councillor, and then in the second mandate I was the first deputy commune chief and in the third mandate I was a commune chief. On top of that, villagers trust in me and they like me, so they voted for me. (A female commune chief, KS commune, Steung Treng province, 12 May 2014).

Those female commune chiefs described above noted that their work experiences were very important for them. Their work experience allowed them to move from one position to another position, ranking from village volunteers to NGOs workers and to commune chiefs. The work experience is one of the main reasons that women leaders are being approached by the political parties and being elected by villagers.

\subsubsection{Conclusion for the Relevance of Type of Work Experience}

The three types of women leaders in three communes provided evidence that if women want to become local leaders, they must have work experience helping poor villagers in their local context. Women leaders thus need to build a relationship with villagers and let them be judged by their job performance. Women can build it up step 
by step from working as a volunteer in a village, then with some local NGOs, and lastly with the commune. The political parties and villagers are also interested in women who have these kinds of work experience and are likely to give opportunities to women so they can eventually be elected to become local leaders.

\subsection{Personal Characteristics (Internal Factors)}

During the interview, a question was asked regarding what kinds of characteristics women leaders should have. All participants mentioned different aspects. Some people said women leaders should have characteristics such as being soft in nature, friendly, gentle, nice and ordinary. Others mentioned education, personal drive, bravery and confidence. Some people mixed all of them together. Therefore, this section will categorise and address those characteristics into four sections: education, personal drive, having a brave/confident character and a gentle/soft/moral/friendly character.

\subsubsection{Education}

The findings in this section showed that in order to become leaders women need an education. However, the level of education does not need to be as high as women leaders in the cities. This section will discuss why education is important and it will also illustrate the level of current education of women leaders in three communes as evidence. Education is the first word that most informants pointed out when they were asked about what a local leader should have as a personal characteristic. They think that when women leaders have an education, they know what is right and wrong. Women can understand the local situation, so they can help villagers. A group of male councillors in KS commune shared their opinion on the characteristics of women local leaders:

We think that the most important characteristic for women leaders is education. Having no education, women cannot become leaders. When they have education, they can provide trainings to villagers. (Male commune councillors, focus group discussion, KS commune, Steung Treng province, 19 May 2014). 
As confirmation, a female commune chief in $\mathrm{KS}$ commune also said herself that based on her education, she can understand women's rights and she can demand gender equality in her commune:

I think I have education and I understand my own rights as a woman. So I can oppose the gender inequality in my village. (A female commune chief, KS commune, Steung Treng province, 12 May 2014).

What education can contribute to women and leadership is that it can build a woman's confidence. When women at local level have no education, they dare not enter local politics and it is also hard for them to get involved. Having an education will allow them to join in local discussions and meetings, which are fruitful for them to access information. A female deputy village chief in KS commune shared her view that education gave her the confidence to work as a village leader and she can understand villagers' situations.

I think my level of education gives me confidence to do the village's tasks and I know my village's situation. (A female deputy village chief, KS commune, Steung Treng province, 14 May 2014).

Villagers also reflected that women leaders should have an education. This education will help not only the leaders themselves, but also villagers. Villagers expect information from leaders, so villagers can seek help from them.

I think that women have education, so they can guess and understand people's feeling. Who are rich or poor? Who have less resource? For instance, some villagers have low income and they seek advice from women leaders. Women leaders teach them how to get rid of debt. Women leaders teach us how to save money. For instance, we have created a Saving Group Association in the village to help those who are in need. People in the group can borrow the money to run a small business. However, men do not care much about this problem. (Villagers, focus group discussion, KO commune, Kratie province, 29 May 2014).

In regards to the quality of education, they referred to the ability of women leaders knowing how to read and write the language and being able to use it to serve the commune and village's tasks. They usually do the advocacy and provide training, deliver administrative services, and solve conflicts for villagers. What is expected from local leaders is that they have a minimum education. It is also hard to find a woman leader who has higher education and is willing to serve the commune or villages. 
A male commune councillor in KP commune confirmed:

Women should have education, but the education here does not mean that women must have higher education. Knowing how to read and write is enough for local leaders. (A male commune councillor, Focus group discussion, KP commune, Kampong Cham province, 12 June, 2014).

A villager also further highlighted:

I think women should have moderate education, have knowledge about commune development, and understand women's issues and lead village to live in a better standard of living. (A villager, focus group discussion, KP commune, Kampong Cham, 16 June 2014).

A group of commune councillors offered their view that at the local level it is different from the cities. The demand for education for local leaders is not high. They just need to have an education level that ensures they can implement the tasks and responsibilities stated in the sub-decree.

The minimum education for women leaders at the village is at least at grade 6 and grade 9 for the commune leaders. If we want to choose women leaders who have higher education than this, I am afraid that we cannot have one. The commune is different from the state (national levels). (Commune councillors, focus group discussion, KS commune, Steung Treng province, 19 May 2014).

Data from the Table 4.1 shows that all of the women leaders in three communes, both in the commune and village levels, have a relatively low level of education. No one had finished higher education or beyond grade 12. Their education level is between grade 6 and 10 counting both the old and new education system. The difference between the old and new education system is that the old system follows French teaching models because Cambodia was a French colony. The education was categorised into primary, secondary, higher, and specialised levels. Currently, Cambodia follows a general education system: $6+3+3=12$ years of schooling. Primary education is from grade 1 to 6: 6 years, lower secondary education is from grade 7 to 9: 3 years and upper secondary is from grade 10 to 12: 3 years. Therefore, to calculate the level of education on both old and new systems, their level of education is between primary and secondary levels, but mostly in the primary level. 
Table 4-1: Level of Education Women Local Leaders

\begin{tabular}{|l|l|l|}
\hline No & Who & $\begin{array}{l}\text { Level of education + } \\
\text { System }\end{array}$ \\
\hline \multicolumn{2}{|l|}{ Commune level } & grate 10 (old) \\
\hline 1 & A female commune chief in KP commune & grade 10 (old) \\
\hline 2 & A female commune councillor in KP commune & grade 5 (old) \\
\hline 3 & A female commune chief in KO commune & grade 7 (old) \\
\hline 4 & A female commune councillor in KO commune & grade 7 (old) \\
\hline 5 & A female commune chief in KS commune & grade 9 (new) \\
\hline 6 & A female commune councillor in KS commune & \\
\hline Village level & can read and write \\
\hline 7 & A female village assistant in KP commune & grade 7 (old) \\
\hline 8 & A female village assistant in KO commune & grade 6 (new) \\
\hline 9 & A deputy village chief in KS commune &
\end{tabular}

Overall, education was important for women leaders, but it did not mean that women must have higher education in order to become local leaders. The demand for education at the national and the sub-national level was different. All participants said that local leaders who are able to read and write the Khmer language are sufficiently qualified. The education in this context means that women should have a minimum education with which they can understand the local problems and they can use it to help villagers out of problems such as domestic violence, land conflicts, health and poverty issues. Women with higher education seem not to be interested in participating in local politics due to reasons which are beyond the scope of the study.

\subsubsection{Personal Drive}

A male councillor in KP commune pointed out that if a woman does not give herself a chance by saying "Yes" when the opportunity arrives, she cannot be a leader in a commune or a village.

Women should have a good heart and have a willingness to serve people if they want to become local leaders. Women should volunteer. For instance, a male village chief will select a woman and he will ask the woman's permission first. If she says yes, then she can start her volunteer's work in a village as a first step. (Male commune councillors, focus group discussion, KP commune, Kampong Cham province, 12 June 2014).

Working with people in the commune and village is not easy. Leaders often deal with lot of issues and their salary is not much, so without personal drive, women leaders may not attain local leadership. Therefore, women from the three communes showed 
that wanting to serve their nation influenced their decision to become female local leaders.

\section{KP Commune}

In recent years, KP commune has experienced social problems such as domestic violence, land grabbing, loan related issues and health problems. Women leaders in the commune and village expressed their interest in dealing with those matters. A female commune chief showed her own commitment in that she wanted to change the old traditional norm that men were the household leaders and that women's issues were not tackled. She hoped that she would be the one who can make the change and help other vulnerable women in her commune.

Being a woman is once in a life time, I want to make my name serving and developing my country. Although I know I have to face some difficulties, I still wanted to lead my commune and develop it. I want to help women mostly because I want to improve their knowledge. Previously, the former male commune chief was concerned about women issues in the local level, so I decided to join in leading the commune because I want to help it, mainly women. (A female commune chief, KP commune, Kampong Cham province, 06 June 2014).

Seeing women and children lack basic health care, a female commune councillor explained that she is willing to take this role although the benefit is not financial. This is because she saw the vulnerability of the poor people who needed her help.

No one told or encouraged me to work for the commune; I wanted to do it by myself. I wanted to help women and children in my villages. I wanted to educate them on pregnancy issues and how to take care of both mother and babies' health. I often urge women to access the local health center when they are pregnant. When I worked as a volunteer in the village, I saw many problems that women and children have. Poor people do not have money to cure their health problems. I helped and brought them to hospital. Sometimes I accompanied them to hospitals in the city. I want to help poor people in my village physically and emotionally. Therefore, this is the motivation that keeps me sticking with the job. If women do not want to be involved in working with the commune, it will not happen. Some people have the ability to work, but they are not interested in this complicated job. The salary offered at the commune or village is not much and if they run business, they can earn more than commune's job. Thus, if we do not have the internal will, we cannot work for the commune (A female commune councillor, KP commune, Kampong Cham province, 9 June 2014). 
As being part of her village, a female village assistant repeatedly emphasized that she liked to help people as part of her personality. She did not care much about financial rewards that she got from serving her village.

The main reason that I wanted to do this job is that I want to serve people. Although I know this job is no benefit, I want to help people as I always do. (A female village assistant, KP commune, Kampong Cham province, 10 June 2014).

\section{KO Commune}

In discussions regarding personal drive, two women leaders in $\mathrm{KO}$ commune revealed their thoughts and their willingness to serve their community. They were the driving factors for them to step up into local politics. They all knew that in their commune a lack of women leaders' representatives who can help on women and children issues and other issues was a problem. They also knew that they are the women who are ready to listen to people's needs and the new generation women who hope to see changes in their commune. A female commune chief in $\mathrm{KO}$ commune also stated her willingness to serve her commune. One of her aims was to help other women in her commune. She knew that women in her commune had a lot of problems and they needed a women leader with whom they could share their problems. Thus, because of wanting to help other women, she decided to serve them by becoming their leader.

Actually, I want to have more women in social work, so I decided to take part in commune works. If there are more women leaders, problems that people face will be solved because women leaders stay closer to people. People are also likely to approach women leaders for help. Women work fast and effectively and women know women's problems better. (A female commune chief, KO commune, Kratie province, 21 May 2014).

Another story coming from a commune councillor is that she was able to be a leader because of her internal strength and she wanted to make a contribution to her society. She pointed to an interesting key message that her society needs women leaders who can share half of the responsibility with men. Women leaders can inform and understand women issues better than men. Moreover, she said that women help in women's matters such as social welfare, living condition, legal issues, land issues, domestic violence, and children's affairs. This can be done because women will share experiences and differences and discuss how to deal with issues both outside and 
inside the house together. Often problems or challenges are barriers for women to become leaders, as this participant explained:

Let's me give you a simple example, in a family if there is only the father and no mother, all children do not have that comfort/warmth from parents. So, women have the duty to walk equally with men, and then society will be improved. Moreover, women are considered as a mother of the world and also a back bone of the society. Comparing to our body if there is no back bone we cannot do anything. Therefore, all of these ideas give me motivation and I decided to be a leader. The will from within my heart is the key to serve society. I am willing to work without conditions. I hope that women in the next generation will have the same will like me. We want to serve our society. The more women participate in local politics, the more problems will be solved. For instance, women will raise their small difficulty or challenges within their household for discussions and solutions. If women want to do big things they have to deal with small things first. (A female commune councillors, KO commune, Kratie province, 23 May 2014).

\section{KS Commune}

This finding from the KS commune is not too different from the other two communes. This commune has many domestic violence cases. Most vulnerable people such as women and children are affected by the consequences. A female commune chief wanted to reduce domestic violence which was the push factor to encourage her to take her current role. She hopes that her involvement will make some changes.

What has influenced my aspiration is domestic violence. I think domestic violence is the main issue in my commune and I wanted to solve this problem. I do not want to see the conflict increasing in my commune. Every year I try to reduce cases of domestic violence and help my villagers. (A female commune chief, KS commune, Steung Treng province, 12 May 2014).

Another interesting experience to be shared by a female commune councillor indicated that because she wanted to help her village and wanted to contribute to develop her commune, she decided to be a leader without much support from her husband.

I wanted to help my villagers and I wanted to see development in my commune, so I decided to work for the position. Firstly, I asked my husband for advice and permission, but my husband did not want me to participate in the commune's works because he said that I did not have the capacity to do this job. You know what I responded to him. I said to him that I knew my capacity is limited, but I wanted to try. You could see other women in the commune, who have low education but they can do the job. Their level of education is just in grade 4 or 5. My husband did not respond. Still I decided to 
take that role because I like it and this career provides me knowledge which is useful not only for my family (husband and children), but also for my community. What I can help for my community is that I can educate villagers on domestic violence, gender, HIV Aids, illegal drug and etc. (A female

commune councillor, KS commune, Steung Treng province, 13 May 2014).

Upon seeing real local problems happening around their lives such as domestic violence, land grabbing, loan issues and health problems, women in the three communes wanted to take part in the commune and village's work. They wanted to reduce those causes and see women and children have a better life. Their personal drive and saying "yes" to any leadership opportunity given to women have been a powerful push for them to become local leaders. Even though they know they may have less benefit from it or less support from their husbands, they still devote themselves to their community and country. Hence, a strong personal drive opens doors for new leadership opportunities.

\subsubsection{Bravery/Confidence}

A key aspect of the ideas on personal drive was bravery or confidence: a quality noted by other people, but also by women leaders themselves. Women were no longer bound within the traditional concepts that they should be silent and avoid decision making positions where men mostly dominate. Male councillors and villagers now wanted to see more women leaders who dared to speak up and take leadership positions. Three points of views about this aspect from women leaders, male commune councillors and villagers are expressed below.

\section{Women leaders' point of view}

Women leaders saw their bravery or confidence as a catalyst for them to reach their dream. The behaviour of some female local leaders in the communes showed how they were brave or confident enough to catch the opportunity of a leadership role.

\section{KS Commune}

Specifically three women leaders in KS commune: A female commune chief, a female commune councillor, and a female deputy of a village in KS commune, Steung Treng province reported on their bravery.

A female commune chief expressed: 
I would describe my personality as that I am brave. If I find something which is not right I will speak out immediately. I will not keep it inside. For instance, when I see injustice I will speak out and challenge for women's rights. (A female commune chief, KS commune, Steung Treng province, 12 May 2014).

The view was echoed by the other two female leaders who explained the confidence that drove them to leadership roles. A female commune councillor said:

I am always confident in myself. If I think that I can do it, I will go for it. (A female commune councillor, KS commune, Steung Treng province, 13 May 2014).

A female deputy chief stated:

I think my level of confidence gave me confidence to do this job. (A female deputy chief of a village, KS commune, Steung Treng province, 14 May 2014).

In addition, during an informal talk with a female deputy chief in KS commune she shared her view:

Women need an opportunity and bravery to be leaders. Without the bravery, the leadership opportunity means nothing. (A female deputy chief, KS commune, Steung Treng province, 15 May 2014).

\section{KP Commune}

A female commune chief in KP commune, Kampong Cham province, also expressed the view that when there was an opportunity given to her, she found the confidence and she dared to accept the opportunity. She showed that she was ready to take a leadership role. The bravery within allowed her to reach her career goals.

When there was a demand from the government to have 30 per cent of women leaders in the commune level, a person at the district came and asked me that if I won the election and became a commune chief, would I accept the job. I said to them that I was not afraid of anything. If I was elected, I would do it. Finally, I was elected and became a commune chief. (A female commune chief, KP commune, Kampong Cham province, 06 June 2014).

\section{KO Commune}

In Kratie province, a female commune chief of $\mathrm{KO}$ commune also stated her view that although she understood there was a push from the government to see more women 
participating in leadership roles at both national and local levels, women first must be confident and brave in order for them to take leadership roles.

I think that although the government reforms have had an impact on women, women themselves should have the bravery and they should dare to participate in the society if they want to become leaders. (A female commune chief, KO commune, Kratie province, 21 May 2014).

\section{Male commune councillors' points of view}

Male commune councillors are the people who work closely with female commune chiefs or other female members. They know the nature of working at the commune level and they are also the people who may or may not support women as leaders. From their perspectives also, women should be brave. A brave leader can handle a commune or village's tasks because the leader can discuss and make a decision with other workers to solve any conflicts which have happened. A woman leader has to show others that she is strong enough to manage critical cases. Woman leaders amaze their male counterparts when they are confident or brave, so male counterparts will accept the fact that women can work with them smoothly. Political parties also seek a brave women leader to work for them because a brave leader will be active and gain a lot of support for political parties. They will take risks to pursue goals.

A group of male commune councillors specifically talked about bravery as a key internal factor for women local leaders.

We think that women leaders should be brave as part of their internal strength. (Male commune councillors, focus group discussion, KS commune, Steung Treng province, 19 May 2014).

To support the above view, a male commune councillor shared the story of his work experience with his female commune chief when they went out to solve a problem at night time:

Our female commune chief is very brave. She worked with us sometimes until 1 or 2 O'Clock at night time. We went to solve a conflict in a village together. (A male commune councillor, focus group discussion, $\mathrm{KO}$ commune, Kratie province, 28 May 2014).

Political parties are the gatekeepers to women's promotion within the parties and they are also interested in someone who is brave enough to do advocacy work and be the representative for collecting more votes for the political parties. 
My political party told me that I must be brave and dare to make decisions on my own if I want to climb up to a higher position. (A female commune councillor, KO commune, Kratie province, 23 May 2014).

\section{Villagers' point of view}

The villagers' point of view was not too different from male councillors. They understood that women now have equal rights to men and can do men's work. The findings indicated that villagers in different communes shared a similar view of their women leaders. They wanted to see their women leaders as brave enough to lead and advise them. They liked women leaders who dared to speak in public meetings and act on their behalf to seek support from others to help their commune.

Ming $\mathrm{Ri}$, a villager in $\mathrm{KO}$ commune offered her view:

Women leaders should be brave. They must dare to work with challenges. Previously, people said women were busy running around the kitchen. However, women in recent society have equal rights to men. Women can do men's work. Furthermore, women should participate in local meetings, so they know social work. Then, when they have knowledge and they are brave and they can do men's work. (Villagers, focus group discussion, KO commune, Kratie province, 29 May 2014).

Another villager in KS commune also shared her view from her real life example:

Women should be given more opportunity and women themselves must be brave. I have noticed, most women are shy and afraid of speaking in meetings. Women often think that their answers may be wrong. For instance, a woman was shaking when she was pointed at to share her idea in a meeting. She was given microphone to speak, but she hid it behind her back. I think most women are like that. Therefore, I think if we want to have more women leaders, women should be told not to be scared of speaking. They must be brave. When they are brave and dare to speak, then they can teach us. (Villagers, focus group discussion, KS commune, Steung Treng province, 16 May 2014).

To sum up, the findings above illustrate three points of view sharing the same thing; that women should be confident or brave if they want to involve themselves in leadership areas. The brave or confident leaders are considered to have the ability to stand up on behalf of political parties and villagers. Thus, bravery is not only demanded from other male counterparts and political parties but also from the villagers who expect a brave or confident female leader who can guide or be relied on when needed. 


\subsubsection{A Gentle/Soft/Moral/Friendly Character}

A gentle, soft, moral, friendly character was also identified as important for female leaders. This idea is culturally and traditionally influenced by the idea of a good Cambodian woman. Women in the past were thought to be gentle, obedient and shy. Women were shaped by the traditional Chbab Strey (Rule for Women): They were required to stay at home to serve and respect their husbands, to do household chores and to look after children, while men were shaped by Chhab Proh (Rule for Men): They had more privileges than women because they have more freedom to act according to the social hierarchy (Brickell, 2008; Cambodian Center for Human Rights, 2013; Ministry of Women's Affairs, 2005). In the current leadership context, these rules have been loosened. Women local leaders do not have to be shy, but they must have good-manners. The well-mannered behaviour means "gentle and soft". The word "moral" refers to women leaders who should know what is right and wrong and must have a good judgment based on their fairness and honest. The word "friendly" in this context means that women leaders are expected to be helpful, kind and welcoming to both rich and poor villagers.

From the three communes, the findings showed that a characteristic of women local leaders, both in the commune and village levels is that they should also be gentle, soft, moral and friendly because these characteristics will help women leaders to create good relationships with villagers and male co-workers. In the Cambodian mind-set, people do not like women leaders that have improper behaviour like an aggressive nature or the tendency to drink too much. They like a leader who speaks nicely to them and welcomes them. This thought mainly refers to women leaders because culturally women in Cambodia are expected to be soft and gentle. Women leaders for today must also have strong moral principles and treat people equally.

\section{KP Commune}

In the interviews and observations, three women leaders in KP commune stated characteristics that women leaders should be friendly, fair, kind and gentle. Male commune councillors and villagers expressed the same opinion.

Friendly behaviour is used by a female commune chief in KP commune. She said that it is her strong point that she behaves nicely to both rich and poor villagers. She likes 
talking to them and discusses whatever issues that they have. She understands how a leader should behave to fit with the local context.

I think my strength is that I do not discriminate against people. I make friends with both poor and rich people. I am different from some women who want to make friends with rich people only. Moreover, I am not bored with speaking and working. I never say no to anyone who comes to ask for help. (A female commune chief, KP commune, Kampong Cham province, 6 June 2014).

A female commune councillor also paid attention to the way she spoke. She said that she knew what kind of language that she should use to speak to villagers. The language that people use is important and reveal how polite people are. Thus, being a leader means people must not behave arrogantly or show power to influence villagers. A leader in this local context needs to show politeness and gentleness.

I think the way leaders speak and the language that they use are important. I know how to ask about people's needs in villages. (A female commune councillor, KP commune, Kampong Cham province, 9 June 2014).

At the village, a female village assistant also used her kind and friendly behaviour toward villagers. She treated them like brothers or sisters. This behaviour is valuable in rural areas because people live in a close community. They know and help each other when in need.

I often call them for meetings and I sometimes give some medicine to them for free (A female village assistant, KP commune, Kampong Cham province, 10 June 2014).

Another idea from a male counterpart was not much different from the three leaders above. He mentioned women local leaders' behaviour and said that a soft nature is something that women leaders must have. He added that women should also be firm because they have to lead a commune which has many issues to deal with. It is not easy to manage, like housework at home. He suggested:

Women leaders should have a rock heart, but behave softly ${ }^{4}$ I mean "soft and firm". If women cannot do like this they cannot be elected. It is not easy for a woman to lead a big commune. (A male commune councillors, focus group discussion, KP commune, Kampong Cham province, 12 June 2014).

Again, villagers also liked a leader who is friendly and easy to approach. From their perspective, a leader must be a role model for others, so their behaviour was a critical concern.

\footnotetext{
${ }^{4}$ The word "softly" means that women should not behave aggressively.
} 
A woman leader should have good characteristics ${ }^{5}$ and be a role model for others. Women should have characteristics that villagers like to make friend with. (Villagers, focus group discussion, KP commune, Kampong Cham province, 16 June 2014).

\section{KO Commune}

A common perception was found in the second commune that women local leaders should be friendly, sweet, and moral in order to gain support, trust and respect from people. These leaders understood that the way they behaved and spoke influenced their leadership career. These women local leaders linked their friendly behaviour to the trust that villagers had for them.

A female commune chief expressed her ideas and gave her real life examples about how she interacted with villagers who came to seek her help. She was quite popular in the commune due to villagers liking the way she behaved. She did not discriminate against people and she used soft words toward them.

I think we, women leaders, should maintain our character. We should have morals. We should speak and communicate to villagers properly ${ }^{6}$. For example, when people come to seek services at the commune, we have to look at them and ask them what they want us to do to help them. We welcome them. What I have heard people say about me is that I am friendly and know how to communicate with villagers. When we do good things to people, people will like us. I often heard from people saying that I am friendly and I speak sweetly $^{7}$. I think I am fair, friendly, show solidarity ${ }^{8}$ and am a moral person. Moreover, I am a simple person and I do not discriminate against other villagers. (A female commune chief, KO commune, Kratie province, 21 May 2014).

A female commune councillor in the commune raised issues about gaining trust from villagers. She said trust was not easy to build between leaders and followers, but she could get it from villagers because villagers liked her sweet words. She knew women would take this way of speaking to communicate with villagers in order to gain popularity. She expressed it as:

I think I am popular because I am good at communication. Villagers like me and trust in me and they listen to me. When they come to seek my help, I

\footnotetext{
${ }^{5}$ Villagers refer the word "good characteristic" to gentle, soft, moral and friendly person.

${ }^{6}$ Properly here means well-mannered.

${ }^{7}$ Sweetly means that women leaders know what kind of words or languages that people would like to hear. They speak those words in a kind way.

${ }^{8}$ The word "solidarity" refers to women leaders who have a quality of being certain and strength that can show they cooperate with other political parties and male counterparts.
} 
speak sweetly to them and I know how to use the right language that they like to hear. (A female commune councillors, $\mathrm{KO}$ commune, Kratie province, 23 May 2014).

Interestingly, a female village assistant also knew her local situation and knew how to interact with villagers. She used nice words and friendliness to solve local conflicts.

I think I do not have any talent, but when I speak to villagers, they listen to me. I think women leaders should be clever and know the local context. For instance, when there is domestic violence in a village, I speak kindly to the person who created the problem and then I give him advice. (A village assistant, KO commune, Kratie province, 26 May 2014).

Male commune councillors in this commune expected their local leaders to be fair and gentle. This was because the nature of working at the local level needs a leader who was clever enough to work cooperatively with others. They did not want to work with women leaders who were arrogant or aggressive.

We want to have women leaders who have a sense of morality ${ }^{9}$. Women leaders know how to work as a team with male counterparts. Men leaders should do the same thing too. (Male commune councillors, focus group discussion, KO commune, Steung Treng, 28 May 2014).

Villages in the KO commune said that they liked soft and gentle leaders too. They said this kind of leader would gain respect and support from them. A soft leader will listen to their needs and can get along with them, especially the poor. A soft leader, from their perspective, does not divide people socially. Rich or poor people are equal in front of the leaders.

Women leaders must have soft and gentle characters in order to be a role model for other women. For instance, if she wants to give advice to someone and her behaviour is inappropriate ${ }^{10}$, she cannot teach villagers. Women leaders should show their respect to others and be simple. Do not think that they are richer or poorer. If they have a good character, villagers will respect them. Villagers prefer women leaders who speak sweetly and are conscientious of villager's needs. (Villagers, focus group discussion, KO commune, Kratie province, 29 May 2014).

\section{KS commune}

The findings in the KS commune showed that the way of communication between leaders and villagers was important. If a women local leader knows how to approach villagers and make villagers listen, then that is a positive outcome. How to make that

\footnotetext{
${ }^{9}$ Morality refers to a person who has good behaviour and character which shows his/her understanding of justice and honestly.

10 "Inappropriate" refers to a bad or foul temper.
} 
communication happen is questionable. All three female local leaders, male commune councillors and villagers in this KS commune revealed several points to help the communication:

A female commune chief shared her own example that she was good at speaking which made villagers like to listen to her.

I dare not say that I am good at speaking, but from what I have noticed is that I can interact with villagers and they listen to me. (A female commune chief, KS commune, Steung Treng province, 12 May 2014).

A female commune councillor also stated that her good communication skills meant she was able to build a bridge between villagers and her.

I think I am good at communication and can get along with villagers and neighbours. (A female commune councillor, KS commune, Steung Treng province, 13 May 2014).

Building good communication was also applied to the village level, a female deputy chief of a village expressed:

I think public speaking can help women become leaders because it can allow for a good communication between villagers and leaders. (A female deputy chief of a village, KS commune, Steung Treng province, 14 May 2014).

All three women leaders above had good communication skills, but did not state clearly that it was a characteristic that leaders should have. Villagers in this commune helped to answer this doubt by claiming that women leaders should have soft and gentle behaviour in their people skills. These behaviours would build good communication between leaders and villagers. Thus, leaders would gain trust and popularity from villagers and they would be satisfied with leaders' behaviour in a way that they would them like to follow. Villagers explained:

Women leaders should be gentle because we want to see soft leaders who dress properly. Moreover, women leaders must be friendly with villagers and care about us. (Villagers, focus group discussion, KS commune, Steung Treng province, 16 May 2014).

In regard to the villagers' point of view above, male commune councillors also had similar ideas. They said that a friendly character would give women a better chance to take the lead in the commune or village.

Women can gain their popularity if they are friendly and know how to interact with villagers like brothers or sisters. She should put herself down to earth. 
From that action villagers can put their trust in her, so when she has the trust, villagers will listen to her. Therefore, villagers will get benefit from her and she also gain their support too. (Male commune councillors, focus group discussion, KS commune, Steung Treng province, 19 May 2014).

In conclusion, findings from the three communes revealed that it was essential that women leaders have gentle, soft, moral and friendly characteristics. These behaviours enriched the relationship between the leaders and their followers. When women applied these characteristics, they gained respect and support from both male coworkers and villagers. People in rural Cambodia liked a woman leader who was down to earth and listened to their problems and treated them like brothers or sisters. Furthermore, a male councillor in KP commune mentioned that women must be strong and firm too. This is because leading a commune or a village is not easy for women who want to become leaders. There are many issues for local leaders to solve.

\subsubsection{Conclusion}

To conclude this section, women should have particular internal characteristics to be able to become local leaders. They need to have four main internal strengths such as being gentle, soft, moral and have a friendly character. They also need an education, personal drive, and a brave or confident character to reach their leadership dreams. The first characteristic of being gentle/soft/moral/friendly can enrich the relationship between the leaders and followers. In addition, women leaders must have at least a minimum education in which they can read or write the Khmer language. This level of education can help women to understand local problems and help villagers on administrative issues and solving conflicts. Next, a personal drive is an internal flame that causes women to make their decision to participate in local politics. Lastly, women leaders are expected to be brave or confident, which can give them a chance to go further than their kitchen and lead to helping others in need.

\subsection{Resources (External Factors)}

In addition to the internal factors discussed above, women can become local leaders through different resources. The resources are the external factors that encourage more women to become local leaders. Participants in all interviews and discussions stated that due to the new importance of women participating in local politics which has had 
a positive impact on local development, people in both government and civil society are keen to create more spaces for women to enter local politics. There are policy reforms in the government and political parties, NGOs' programmes, and other people's support that share the same aims to do whatever is needed to increase women's participation in local politics. This section discusses the different resources that help to pave the way for women to become local leaders. The resources are divided into reforms/policies, NGO activities, wealth, family support, villagers and mentoring supports, and the women's ability to know the political ropes.

\subsubsection{Reforms/Policies at the Institutional Level}

The government created their reforms and policies to increase the numbers of women in local politics. They include the government's Rectangular Strategy for Growth, Employment, Equity and Efficiency both Phases I and II, the National Strategic Development Plan, the Cambodian Millennium Development Goals, the Sub-Decree on Decentralisation of Powers, Roles and Duties to Commune/Sangkat Council, Decentralisation and Deconcentration reform and other government reform programmes (discussed in Chapter 1). All the reforms or policies recognise women as the backbone of the economy and society. Women have equal rights to access all public sectors including the decision-making positions at the lower levels of government. Due to wanting to improve the presence of women at local levels, women's capacity is being developed, their rights are protected and the gender gap is being reduced in the education sector. Gender mainstreaming was introduced at the local government level and the well-being of women and children is being paid more attention.

These actions combined have had an impact on the mind-set of Cambodian people, both men and women. The findings in the three communes revealed that through the reforms, women now understand their political rights better than in the past. More women are now taking leadership roles at local levels. Men also understood women's rights and have begun to encourage more women to take leadership roles. 


\section{KP Commune}

A female commune chief in this commune recognized the importance of the government reforms that gave her a chance to be involved in local politics. She said that because of the government demand for 30 per cent of leaders to be women, she was able to become a leader in her commune.

I think the government reforms have had a positive impact on women and leadership because I can see more women involved in local politics now. Previously, there was no female commune chief. When there was a demand from the government to have 30 percent of women leaders in the commune level, I had that chance and I could become a commune chief. (A female commune chief, KP commune, Kampong Cham province, 6 June 2014).

Not only have the government reforms encouraged women in leadership roles, but men were also more aware and encouraged women too. The reforms have changed men's perception of women that they were weak and could not handle work outside of the home.

Actually, the government encourages women now. They want to have 30 per cent of women local leaders in leading the country. Thus, we male councillors also encourage women because we know that they have the right to participate in local politics. (Male commune councillor, focus group discussion, KP commune, Kampong Cham province, 12 June 2014).

\section{KO Commune and KS Commune}

Due to this top down approach, a female commune chief in $\mathrm{KO}$ commune stated:

I think one of the main factors that push for more women in local level is the government reforms. The government has been working on encouraging more women in taking leadership roles at both the national and the sub-national levels. (A female commune chief, KO commune, Kratie province, 21 May 2014).

A female commune chief in KS commune also shared her opinion that the government reforms provide opportunities for women. Women are told that they have equal rights as men, so this is an incentive for all Cambodian women.

From my opinion, the government reforms have an impact on women and leadership. The government reforms want to increase more women leaders at all levels. This shows a good sign for women who want to be a leader. Because of the government reforms, women now understand their rights. (A female commune chief, KS commune, Steung Treng province, 12 May 2014). 
In brief, due to the government reforms, women seem to have more space in local politics. The government promotes women's rights and also expresses their interest in seeing more women leaders helping the country, which cause men to accept the presence of women leaders. Women at the local context are also aware of their own rights and that they can participate in politics like men. They can use their knowledge and ability to contribute to society.

\subsubsection{NGOs activities}

Non-governmental organizations' activities in Cambodia have had an impact on local development, especially with regards to women. They work through media, development advocacy and capacity building to raise awareness about gender equity. From my observations, they work closely with local authorities and villagers. One of their aims is to provide training for women in leadership. They bring knowledge to women and men. Women are also told about their equal rights to men. They train and encourage women how to be brave and confident in order to become leaders. The important thing is that NGOs provide working experience to women, which is discussed in the previous chapter. Findings from the three communes are separated in the section below.

\section{KP Commune}

What was found in the commune is that some NGOs had conducted their training programmes with women. Both the female commune chief and a male commune councillor revealed and agreed that women's knowledge improved when women were called to participate in the training programmes run by NGOs.

A female commune chief said:

I participated in some training programmes run by NGOs and they are useful because my knowledge has improved more than 50 per cent now. (A female commune chief, KP commune, Kampong Cham, 6 June 2014).

Another male commune councillor highlighted that some of the women in his commune were trained by an NGO to work on health care. This can build their capacity which may be useful for their future career.

Some women volunteers were selected by Share NGOs to assist in local health care. (A male commune councillor, focus group discussion, KP commune, 12 June 2014). 


\section{KO Commune}

The findings in the $\mathrm{KO}$ commune revealed a broader view. The NGOs' activities have worked not only with women, but also with men and other villagers in general. Both men and women were trained about women's rights and they were told that women can work outside the house. Men had to open their mind and accept the change. Women have the right to get knowledge and know about social issues via participating in local meetings. They were trained how to be brave, confident, and independent in order to pursue their dream if they want to be leaders.

A female commune chief shared her own experience of working with NGOs before she was able to be a leader.

I think NGOs' activities are to develop women's capacity in my commune. They trained women how to be brave, so women can participate in politics and deal with problems in the society. For instance, I have working experience with NGOs. I worked for VFP NGOs before I was able to become a commune chief. Moreover, there is an NGO (KADOC) working to develop women capacity in the commune. They trained women how to be brave, so women can participate in politics and deal with problems in the society (A female commune chief, KO commune, Kratie province, 21 May 2014).

The above view, echoed by the two female leaders below, who then explained that their confidence and willingness to be leaders was influenced by the NGOs' activities. A female commune councillor also suggested that NGOs played an important role in training local women. She has been trained and her willingness to serve her community was raised. Thus, from her experience, she wants to see more women following her footsteps.

The strategies to build women's confidence are the communication and advocacy, like I have been through. I work with NGOs partners who come to help the commune. I sometimes seek support from them. I want to see more capacity building for recent women leaders. For instance, I was also trained by NGOs to work cooperatively with male counterparts and they encouraged my willingness to help the society. Both government and NGOs should train women on how to encourage women, so they can help the society. (A female commune councillor, KO commune, Kratie province, 23 May 2014).

A female village assistant claimed that the positive outcome of the NGOs' training programmes has built her confidence and her leadership skills.

I joined in some training on domestic violence, human trafficking, women and leadership. From the training, I have more confidence and they taught me how to transfer my knowledge to villagers. In the future, I want to have short course 
trainings for women, so women can have more understanding and knowledge. (A female village assistant, KO commune, Kratie province, 26 May 2014).

What NGOs have done beyond the training to some local leaders is that they have introduced the idea of equality to men and villagers.

A male councillor said men should be proud when they see their women do good things for society. For instance, becoming a local leader, and he also stated that the involvement of women in local politics was crucial, and cannot be overlooked.

People and international NGOs in the world consider women positively and they encourage women. If the wife is good, husband will be good. Women and men live with each other. So, working should have women's involvement. Previously, women were less value and they compared women to kitchen maids. However, today women have equal rights to men. (Male commune councillors, focus group discussion, $\mathrm{KO}$ commune, Kratie province, 28 May 2014).

Villagers indicated in their views that they felt they were no longer trapped in the old myth that women were to be kept busy in the kitchen where they could not expose themselves to political spheres.

From the training, we now know women have equal rights to men. Women can do men's work. Women can participate in local meetings and they know social problems. Women are told to be brave and not to wait for money from men. We can work for our living, which is not like before when women were busy in the kitchen and relied on men for income. (Villagers, focus group discussion, KO commune, Kratie province, 29 May 2014).

\section{KS Commune}

The experiences of the three women leaders in the KS commune showed clearly that NGOs have an impact on their life on four things in particular: confidence, equal rights information, capacity building and new knowledge. NGOs trained them and built up their confidence through enhancing their knowledge on particular issues, especially gender issues. The NGOs also use women leaders in their network. This network also brings new knowledge to help villagers.

A female commune chief stated:

I have joined training held by SILAKA (provides trainings on gender equity, accountability and effective management and advocacy) and GADC (to advocate for gender sensitive projects/programmes, national law and policy formulation in Cambodia). I joined a workshop in the Philippines in 2008 supported by SILAKA as well. I think all the training are useful because I can bring new knowledge into my community such as women issues, gender and 
women rights, agricultural knowledge and family gardening. (A female commune chief, KS commune, Steung Treng province, 12 May 2014).

A female commune council said:

PYD NGO came to help my commune. They provide training on gender issues and others. The training delivered good message to villagers. (A female commune councillor, KS commune, Steung Treng province, 13 May 2014).

A female deputy chief of a village also claimed:

I joined a training organised by PYD. The training was about women empowerment and women and leadership. This training was useful because it gave women confidence. Women understand their rights, so men cannot look down on women. (A female deputy chief of a village, KS commune, Steung Treng province, 14 May 2014).

To sum up, NGOs' programmes to help local development are crucial and have a positive influence on women and leadership. Most female local leaders have joined in workshops or training run by NGOs (PYD, VFP, KADOC, and Silaka). They introduce the idea of equality and let women escape from the world where they were trapped at home and busy around the kitchen. Local women are trained on how to have confidence to serve their society. They conduct training workshops for local women who they think will be potential leaders who can bring new knowledge to their society in the future. They have brought knowledge of gender equality to both men and women in the three communes. Thus, when men and villagers understand the important role of women in helping the commune, women seem to have the space to move up to leadership positions, as there is less resistance. The NGOs help to change attitudes toward women.

\subsubsection{Wealth}

From the interviews and discussion in three communes, women leaders in the local contexts are expected to be relatively wealthy or better off than very poor villagers. This means that women must have additional income apart from the commune's salary (Table 4.2). This was because their monthly salary is not enough for their living expenses. The supplementary income covers their household expenses. If a woman leader is very poor, she cannot help other people's problems, as she is also in need. More than this, women leaders who have a stable living can easily create good relationships with villagers. This is because when villagers seek their help, they can respond to them quickly in terms of giving rice, money, and other resources. Table 4.2 
below illustrates the additional income of women leaders in the three communes beside their monthly salary.

Table 4-2: Additional Income of Women Leaders in the Three Communes

\begin{tabular}{|l|l|l|}
\hline No. & Position & Additional income \\
\hline KP commune & $\begin{array}{l}\text { Sell construction material such as sand and } \\
\text { stone }\end{array}$ \\
\hline 1 & A female commune chief & Sell dirt for filling ponds \\
\hline 2 & A female commune councillor & Sell boiled potatoes \\
\hline 3 & A female village assistant & \\
\hline KO commune & Family members/gardening/farming \\
\hline 4 & A female commune chief & Gardening \\
\hline 5 & A female commune councillor & Work with NGO \\
\hline 6 & A female village assistant & Farming and gardening \\
\hline KS commune & A female commune chief & Gardening \\
\hline 7 & A female commune councillor & Gardening and grocery store \\
\hline 8 & $\begin{array}{l}\text { A female deputy chief of a } \\
\text { village }\end{array}$ &
\end{tabular}

\section{KP Commune}

From the discussions, each woman leader in this commune had her own business besides working for the commune or village. A female commune chief and commune councillors said:

I do not have other roles apart from the commune chief position, but I run a small business. I sell construction material such as sand and stone. (A female commune chief, KP commune, Kampong Cham province, 6 June 2014).

I sell dirt for filling ponds, so people can build their houses on them. (A female commune councillor, KP commune, Kampong Cham province, 9 June 2014).

An opinion from a commune chief's husband expressed that women leaders must have some money in order to make friends with villagers. Women leaders must be able to contribute social events, such as informal gatherings or parties in the villages.

If you want to be a leader in the commune, you must have your own business. If not, you cannot be a leader because this position does not give you enough money for a living. For instance, you must know how to drink or give money to villagers to buy drinks, so then you can get along with villagers. (A commune chief's husband, focus group discussion, KP commune, Kampong Cham province, 17 June 2014). 


\section{KO Commune}

A female commune chief was also better off compared to other villagers. She got financial support from her five daughters who were married to rich men. Her son-inlaws were all in the military. They sponsored the building of a good road for the commune. Thus, although this commune chief does not have her own business as some women leaders in the KP commune, she had good support from her family. She did not have to worry about her living costs which gave her more time to help others. A male commune councillor said about her female commune chief that her living situation was better off so she had nothing to worry about regarding her household economy.

I think women should have a better standard of living because the commune's salary is not much. For example, the female commune chief has a house and cows. On top of that her children are all better off, so she does not worry about her basic needs. Sometimes I saw her giving her own money to help vulnerable people in the commune. (A male commune councillors, focus group discussion, KO commune, Kratie province, 28 May 2014).

\section{KS Commune}

The findings in this commune are not very different from the other two communes. A woman could become a leader when she had a stable standard of living. A female commune chief also connected the life of women leaders with money.

Based on my daily observation, if they want to choose you as a commune chief, you must be better off compared to people in the commune. If you are poor, you cannot go far. For instance, if you are poor and lack basic necessities such as money or a house, you will have difficulties becoming a leader. (A female commune Chief, KS commune, Steung Treng province, 12 May 2014).

As a result, women leaders in the three communes, both in the commune and village levels were expected to be relatively wealthy. This was because the monthly salary from the commune or village was not much to support their living. All of them had their additional income beside the salary. Some work on their garden or farm and others ran minor businesses and some got financial support from family members. These kinds of jobs sometimes demanded a personal contribution, so when women leaders did not fall into extreme poverty, they could think further ahead and have the ability to help villagers. 


\subsubsection{Family Support}

Most participants in all three communes claimed that family support was one of the key factors that help women to become local leaders. Female local leaders pointed firstly to their husband and then their wider family members who supported them. For instance, they said that their husbands devoted their time and energy to sharing household chores and other family business. They understood that their wives had a duty to serve the commune and village. Apart from husbands, family members such as children were pointed out as the next people who shared household tasks. However, among nine female leaders in both commune and village levels, two female village leaders were widows and said that they were free from family responsibilities. They did not have to serve their husbands. Although they were widows and had no husband to support them, they had other people in the commune who encouraged them.

\section{KP Commune}

From the backgrounds provided by the three women leaders in the KP commune, two female commune leaders claimed that they had support from their husbands, and that one female village leader was a widow.

The female commune chief had very strong support from her husband who was a commune chief for nearly nine years. Her husband was very thoughtful and helpful. He decided to be the main person in his family who was responsible for the household business and the household chores. He was happy to accompany his wife at any time when she needed him to help her with some tasks at the commune.

I got married in 1990. I have four children, two boys and two girls. My husband was a commune chief for nine years. In 2002 he worked as a district councillor. Now he is at home and helps me to manage our business. Previously, I was the one who earned income for the family. When I was elected as a commune chief, I asked my husband to stop working in order to manage the business for me. He also helps me with the household chores because my children are busy with their study and I am busy with the commune's work. Therefore, I think my husband is very supportive and he dedicates his effort to help me. For instance, he is often my driver when I have a meeting at the district or province which is far from my house. He waited for me outside until I have finished the meeting. He is a very supportive husband. Regarding my job I sometimes leave him at home too. Thus, women leaders need support from husband. If my husband does not allow me to work for the commune, I cannot go far. (A female commune chief, KP commune, Kampong Cham, 6 June 2014). 
In regards to the idea above, an informal talk with the commune chief's husband showed that he played a role as a mentor. He was her back up and he always taught and guided her in how to interact with people and deal with local issues. This was because he was a commune chief himself. He still has power and good connections with other male commune councillors and helped his wife by calling for meetings because he had a strong social network with those male commune councillors.

Because my husband used to be a commune chief, I have learnt from his work a lot. I learnt from his documents. When I was free I read the documents about leadership skills (team work, democracy), development works (road constructions, irrigation system) and administrative works. So, I have already absorbed about 50-60 per cent knowledge. (A female commune chief, KP commune, Kampong Cham, 6 June 2014).

Another female commune councillor also received support from her husband when she was busy working at the commune. Her husband was often the one who helped her with family business (selling dirt for filling ponds) and housework. Thus, she felt no constraint on her work for the commune.

I am married and have three children. My husband is a farmer and business man. If there is a demand for me at the commune, my husband always help me with the household chores, children and business. (A female commune councillor, KP commune, Kampong Cham province, 9 June 2014).

However, a female village assistant in this KP commune said that family support was not important to her because she was a widow. She did not have any family burdens and did not need support from family, but she said she was encouraged to work for the village from people in the commune and villagers. This will be elaborated more in the next section.

I am a widow with two children. So I do not have to worry about my family much. I can eat breakfast, lunch and dinner at any time. (A female village assistant, KP commune, Kampong Cham province, 10 June 2014).

\section{KO Commune}

Family support was also one of the important findings in $\mathrm{KO}$ commune. Both the female commune chief and commune councillor shared their view that their family was very supportive and let them be involved in leading the commune.

A female commune chief explained that her husband and others really supported her career as a commune leader. They were proud of her because in their mind-set there 
were not many women who could become local leaders. Her husband was happy to take housework responsibilities from her and let her fully engage in her commune's work. She said a women leader can bring a good reputation to her family members.

I am married and have five daughters. They all have their own family now. Besides my knowledge and experience, I think family support is also important. I can become a leader because I have my husband, children, relatives and neighbours who are support always support me. I am especially proud of my husband because he is so helpful and very supportive. He is responsible for housework: He cooks for me, so when I am home I just eat. Actually, he has his work to do too but he still does housework for me. He has never complained. He wants to see his family have honour, as good in our community by making good contributions to society. If I want to be a good leader, my family should be a role model. Therefore, I think women should have support from their family and relatives. (A female commune chief, KO commune, Kratie province, 21 May 2014).

A female commune councillor stated that her husband knew how important it was for women to lead the commune. This is because he was educated and he was a teacher in this commune. From his knowledge and experience, he knew that women leaders can help women's matters that men cannot solve easily. Thus, she was encouraged by her husband to take the role.

I am married and have five children. My husband was a teacher and also a head of school, but now he is a district councillor. He encouraged me to work in the commune because he said the commune needs women leaders who know women's problems better than men. Since I became a leader, my husband has always supported me and trained me how to solve conflicts in my commune. He has taught me some laws and showed me how to file a complaint to help vulnerable people. (A female commune councillor, $\mathrm{KO}$ commune, Kampong Cham province, 23 May 2014).

\section{KS Commune}

Sharing household chores amongst family members was also a kind of support that three women local leaders in the KS commune described. A female commune chief said that her husband and her children agreed to share household chores with her, although they were busy with their own jobs. This action gave her more time to work fully at the commune. Her husband helped her not only with household chores, but also with gardening and farming.

I have eight children. All of my family members are busy and working as teachers and district officers. My husband is also a helper in building a school. 
In the early morning we all go out to work and for those who go home first have to cook and then we help each other with different household tasks. My husband is usually the one who cooks rice and looks after my grand-daughter. What is important is that my husband has devoted his time for me; otherwise I could not do anything. It means that my husband supports me and we divide our household chores. When I go to work I cannot help my husband but when I am home I help him. This mutual help also applies to farming and gardening in my family. The most influential person to me is my husband. He always supports me. If he does not help me I cannot go anywhere. For instance, if I go out who will cook? So he helps me with the household chores. My husband does not mind women's household chores. (A female commune chief, KS commune, Steung Treng province, 12 May 2014).

Similarly, a female commune councillor shared that her family had divided household tasks since she became a member at the commune. This was because her husband understood that she was busy and had less time at home sometimes.

I have three children. My husband is the head of school at the district. I know at first my husband did not support me when I decided to work for the commune, but now he is ok with that and he helps me with household chores. Every morning we, all family members, go out to study and work. When we arrive home at lunch time, we all help each other with housework. My daughter helps me with cooking, another daughter helps me with gardening and cleaning. My husband chops wood for cooking. He also helps me with the cooking too because he cooks faster than me. My husband understands that I do not go out for pleasure, but I go to work at the commune. Therefore, he helps me with housework. (A female commune councillor, KS commune, Steung Treng province, 13 May 2014).

Beyond the family support, a female commune councillor also revealed that she was encouraged by her father-in-law to work for the commune.

My father-in-law who was a commune chief encouraged me to take the position because he is old and retired. He wanted me to take his turn. (A female commune councillor, KS commune, Steung Treng province, 13 May 2014).

Nevertheless, a female deputy chief of a village claimed that she was more carefree about the family support because she was a widow and had more time to engage with the village's work.

I am a widow with one daughter. My husband left me when my daughter was eight years old. I am alone, so I do not care much about my household chores. I balance my time. If I have a lot of important jobs at the village to do, I will put my housework aside. (A female deputy chief of village, KS commune, Steung Treng province, 14 May 2014). 
All in all, family support referred mostly to female leaders' husbands who were the most important person to support, encourage, help and guide those women local leaders. They did not put barriers on these women leaders. They helped women with both housework and the family business including farming and gardening. Family members such as children also shared their household chores with their mothers. Family support was not so relevant to two female village leaders who are widows. They had other support which is discussed below.

\subsubsection{Villagers' Support and Others' Mentoring}

\section{Villagers' support}

Apart from family support, support from villagers and others was crucial for women who want to be leaders. How to gain the support from villagers and others was the key for women to build their social capital. The findings showed that how women leaders gain villagers' support was not only associated with the characteristic of leaders as described above, but also with the place where female leaders lived. People only trusted someone they knew and who lived in the same place with them for a long time. They were happy to be led by someone with whom they were familiar. They did not prefer a leader who came from the outside. They did not care how highly educated the leader from outside was. They seemed to favour a leader with whom they have been building close relationships. In rural Cambodia, people usually live as a close community and they know each other's individual backgrounds. A group of male councillors stated:

A leader in the local context is chosen from voting and the support from villagers. If we choose women leaders from outside, we are sure that villagers will not support them. I think a person who is able to be a leader must live in the commune since she was young and has participated in the commune activities. (Male commune councillors, focus group discussion, KS commune, Steung Treng province, 19 May 2014).

All the nine female local leaders from the three communes were born in their local areas and still lived in the same place where their parents used to live. They have built their close-knit grassroots community and they have built their mutual connections with their villagers.

Women leaders knew their local situations and have built good relationships with their neighbours or other villagers. Three different groups of women leaders, male 
councillors and villagers expressed their view that the personal connection between leaders and villagers was very important for them.

\section{Women leaders'view:}

In order to gain support from villagers, women leaders have to go through the formal election and selection process. Creating social capital is a means for women to reach their local positions. Women leaders showed that to gain villagers' votes, women have to build good connections with villagers and show them that women are eligible and have enough capacity to lead them. Once secured, this trust encouraged women to become leaders and to achieve their goals.

A female commune chief in KP commune expressed:

I have been living in the commune since I was born. Villagers already knew me because I made friends with both rich and poor villagers. I always welcome them. My position is based on my mandate and if villagers still support me I can continue the job and if they do not, then I have to stop working as a commune chief. (A female commune chief, KP commune, Kampong Cham province, 6 June 2014).

This quote referred to villagers' power when it came to the commune/Sangkat election every five years. Villagers are the voters and they can decide who can be their leader. Thus, women who want to become leaders, have to have the villagers' vote first. Leaders need to be concerned about women and villagers' relationships. A female commune councillor also suggested that women can become leaders if they know how to bridge the gap between the leader and followers.

I think women leaders need to fill the gap between us and villagers. We have to strengthen our relationship with villagers because this way can help us to reach our positions. (A female commune councillor, KP commune, Kampong Cham province, 9 June 2014).

A female commune chief stated that in order to build a good connection with villagers and to gain their votes, women should show villagers that they are a fair leader, and that they can put their trust in them.

All problems that villagers have, they always come to me for help. I provide my service to them fairly. I do not discriminate against anyone, so villagers vote for me. (A female commune chief, KO commune, Kratie province, 21 May 2014).

The trust that villagers give to a women leader motivates them to work for the commune. 
I think women leaders at local level need support from villagers and women should build their relationship with them. For instance, I decided to work for the position because I got support from my villagers. I will work for them with whatever position that they give me. Therefore, the first priority is women should build their popularity among villagers. Then they will trust in you and listen to you. (A female commune councillor, KO commune, Kratie province, 23 May 2014).

\section{Male commune councillors' view}

Male commune councillors also agreed with the idea that women local leaders should build a good foundation with villagers. This was because villagers had the right to choose their leaders to a certain extent.

What is important for a leader is that s/he must be well known by villagers and villagers like him/her. (Male commune councillors, focus group discussion, KP commune, Kampong Cham province, 12 June 2014).

\section{Villagers'view}

Villagers understand their right to vote and they also understand that women can become leaders only if they have support from them before women are selected by the political parties. Discussion with participants indicated that before they select a person to become their candidate, most political parties state that they usually observe a person's background and see whether s/he is popular in the commune or villages or not. If s/he is and is well known by villagers, s/he is easily approached by political parties, especially by the dominant and most powerful political party such as CPP.

Women leaders should do good things that make villagers like her. She must know villagers' needs and treat them fairly. For instance my female commune chief got support and trust from us, so the party will select her. (Villagers, focus group discussion, KP commune, Kampong Cham province, 16 June 2014).

Villagers' support was a kind of motivation that pushed women to become leaders.

I think that the most important thing women leaders need is strong support from us. We give our trust. This motivation will help women leaders to move on even though they get less salary. (Villagers, focus group discussion, KO commune, Kratie province, 29 May 2014).

\section{Others' Mentoring}

Apart from the support from villagers, women leaders also had other support from male counterparts and other women local leaders. They were the mentors to women 
leaders. The two female village leaders who were widows revealed their stories below.

A female deputy chief of a village in KS commune explained that even without family support, she still had many co-workers, both men and women, supporting her:

The encouragement from my villagers is the main motivation to work in this position. Moreover, my female commune chief and other male commune councillors are the people who also encouraged me. (A female deputy chief of a village, KS commune, Stueng Treng province, 14 May 2014).

A widow female village assistant in KP commune stated that she was encouraged to work towards leadership by a male village chief too:

The male village chief encouraged me to work as village assistant. (A female village assistant, KP commune, Kampong Cham province, 10 June 2014).

The view above was echoed by a male councillor. He stated that he would like to have more women leaders in his commune.

I understand women's rights. I always encourage women in politics. For instance, my female commune chief sometimes worked with us until late in the night and I protected her. (A male councillors, focus group discussion, $\mathrm{KO}$ commune, Kratie province, 28 May 2014).

Women also had support from other women leaders. A female village assistant said that she liked to share and discuss issues with other women who have problems. She hoped that she could help other women to become a leader like her.

I want to train young women and encourage them to participate in the village's activities. I want to see more voluntary women work for the community. At my age I do not want to dream high, but I just want to help other young women. Women can share and discuss their issues together. (A female village assistant, KO commune, Kratie province, 26 May 2014).

A female village assistant raised her own example that she was appointed and supported by a female commune chief because she was active in meetings.

I joined in some meetings on domestic violence, human trafficking, women and leadership. The commune chief saw me in those meetings. So, I think I had more chance. She always called me. (A female village assistant, KO commune, Kratie province, 26 May 2014).

To sum up, support from villagers and others were important for women local leaders. Three points of view from women leaders, male commune councillors, and villagers showed that support from villagers was connected to the place and the relationship that women and villagers had built with each other. Building social capital is crucial. 
The more women can bridge the gap between them and villagers, the more easily they can become their leaders. This information shows that the political parties selected their candidates based on how much women and villagers are connected, or are known, in the commune or villages. They have questioned whether women have built a good relationship with villagers or not. In addition, male councillors and current women local leaders also have encouraged more women to take part in a leadership role. Therefore, women need support from local councillors, and current women leaders, to become leaders because they are important in helping women's motivation and willingness to help society.

\subsubsection{Political Ropes}

Political parties are the gatekeepers for women who want to become local leaders. Knowing the political ropes and having good party ties are key to help women get formally elected at the commune level and be selected at the village level. "Political ropes" can refer to both formal and informal connections between women and people who have power in the political parties or to a third person who can influence the decision makers within the political parties. The third person may be a friend or former co-worker of the women leaders. The critical question is how women who want to become leaders can affiliate themselves to the political parties. Some experiences of women leaders in the three communes below will help to answer the question. A male commune councillor noted:

If we want a woman to become a leader, she should get approval from a particular political party first because they have to go through election system in order to become leaders. (Male commune councillors, focus group discussion, KP commune, Kampong Cham province, 12 June 2014).

\section{KP Commune}

A female commune chief and a female village assistant in this KP commune showed that a relationship between the people within the political parties and themselves was one of the causes that enabled them to become leaders. A female commune chief shared her story that she used to know a person at the district level, and that person paved the way for her to become a leader. She had already created a good network with other male counterparts within her party in order to gain their support. This was because members in each party have the power to vote for their candidate and rank 
them in the party list. This connection or networking was crucial for women who wanted to become leaders.

I was asked by a person from the district to stand as their candidate for the third mandate of the commune/Sangkat election. The reason is that I used to work at the district before and the person knew me. When I was newly elected, I was trained to do the job by people at district and province. They have taken care of me. They knew that I am clever and I can handle the job. Moreover, I have built a good relationship with my male counterparts in my party already. I think they are happy to work with me (A female commune chief, KP commune, Kampong Cham province, 6 June 2014).

A female village assistant also revealed a similar story:

I was called to be a volunteer in the village by a man who worked at the district. He and I used to work with each other in the past. I told him that I have a low education and I did not know much about village's work, but he said to me that it was not a big problem. He would inform people at the higher level for me. (A female village assistant, KP commune, Kampong Cham, 10 June 2014).

\section{KO Commune}

Similar findings were found in the $\mathrm{KO}$ commune that creating and using political ropes is one of the best ways for women to climb up the leadership ladder. Both female leaders in the commune and a male commune councillor showed that women should be known by people in the political parties and know how to gain their support.

A female commune chief showed her acknowledgement to her political party and her male co-workers:

My party has selected me to be a leader in the commune. I pay my gratitude to my party because they encourage women and they selected me in their party list. Moreover, my working relationship with male counterparts is okay because they support me. (A female commune chief, KO commune, Kratie province, 21 May 2014).

A female commune councillor stated that building networks with people who have power in the political parties could help women to reach to leadership position.

The party sometimes does not want to put women as their top candidates on the party list. However, if women have had money, network with people who have higher positions in the political party and trust from villagers, women may have more chance to be placed in the party list. Thus, women need both formal and informal networking in order to gain popularity in the political 
parties. (A female commune councillor, KO commune, Kratie province, 23 May 2014).

A male commune councillor stated very clearly that networking is a key aspect of the culture of Cambodian society. He acknowledged that women building relationships with villagers are important, but women also need to know how to build relationships with people in the political parties. A woman's ability to network with people in the political parties should not be taken for granted. Knowing people in the political parties, or using old networks, may help women become local leaders faster and more effectively. Thus, networking is important for women in the local leadership sphere.

I know women need to build good relationship with villagers first, but I think networking in the political parties is the culture of our country. The selection process of leaders is through the political parties. Members in the party will vote for you if you have built a working relationship with them. If you do not know people at the top you cannot get in the political parties easily, only if you are popular among villagers. Then political parties may be interested in you. (A male commune councillor, focus group discussion, $\mathrm{KO}$ commune, Kratie province, 28 May 2014).

\section{KS commune}

In order to get connected with political parties, the findings from this $\mathrm{KS}$ commune showed that women needed to know the political ropes, but they also needed to show their capabilities. Women leaders in the commune stated that they have built their networking with people in the political party and along the way they have also shown them that they have the ability to work with people in the political party and be ready to take a leadership role. Two women leaders, male councillors and villagers in this KS commune revealed this in the following extracts:

\section{Two Women Leaders:}

First, a female commune chief arranged her career path very well. She knew that she had to go through the political parties and gain trust from other male counterparts in order to have her current leadership position.

I am a strong activist in my party. I am very good at leading my commune. Moreover, I do not have any problem with my male counterparts because they like the way I work. I have had a good relationship with my two male commune councillors for the last two years. The important thing is that they trust in me and we help each other. I know the decision making from the political parties is very important. So, women should show people in the political parties that they are 
capable enough to manage the job. (A female commune chief, KS commune, Stueng Treng province, 12 May 2014).

Second, a female commune councillor who did not have the work experience in the village or commune claimed that she was able to get into a leading position because of her good communication with people in her political party. From her story, told below, she recognised that networking with people in her political party is important for her. She has built the necessary relationships with people within political parties before she was appointed to work in the commune.

I knew people from higher positions and they recognized my capacity. They knew me as a loyal and calm person. I have built a good relationships with people at the higher positions very well. Whenever I go to parties or any celebrations, I try to get along with them and make friends with them. Therefore, I think they can see me from this point. Let me tell you how I was selected. The head of the party and I are not related, but the reason he chose me because he knows that I am an active person. For instance, I can do advocacy on behalf of my commune chief. I can work co-operatively with other male commune councillors or commune clerk. They all trusted me. Thus, a strong support from my political parties is needed. Then they will put you as their top candidate on the party list, so you will be easily elected as a leader. (A female commune councillor, KS commune, Stueng Treng province, 13 May 2014).

\section{Male councillors}

Both leaders and members in the political parties can impact the selection of women at local leadership. A male commune councillor also revealed that there is a man in his political party who has the power to select whoever he wants to his local party. The people who are the members in each political party at the local level were also an important network for women. These members usually took part in the selection of local leaders. Both the people at the top and people at the local level within the political parties are the target networking for women. Thus, knowing those people was the key for women who want to become leaders.

I think the top leader from the province is the person who decides who should be a commune leader. I will not tell you the detail of how the internal system in the political party chooses the person. I will tell you the overview of the selection process. At the commune level, people at the province go to ask several former village chiefs to identify key people who have the ability to work for the commune. Then they will select him/her based on their criteria. (A male commune councillors, focus group discussion, KS commune, Stueng Treng province, 19 May 2014). 


\section{Villagers}

Villagers in KS commune were also aware of the fact that people in political parties at the upper levels had the power to select potential local women. Villagers understood that people in the political parties were often the people who come to select women first. Women may not know they are being selected. Therefore, whether women go to approach a political party first or a political party comes to find them, the close affiliation between the woman and the political party is essential.

What I heard is that when there is an election in the commune, a person at the district comes and selects leaders to include in their party list. Their selection is based on working experience and knowledge. Moreover, they will ask the village chief and commune chief in the same party to figure out who should be the best candidate. Sometimes, a woman leader did not know that her name was already selected by the people in the political parties. Her name was already sent to the district and the province for discussion and then they will came back to ask her agreement later. (Villagers, focus group discussion, KS commune, Steung Treng province, 16 May 2014).

In brief, the findings from the three communes indicated that political ropes are one of the main links for women to gain a leadership position. From their experiences, women somehow must network with whatever political party they support and with the people working there. Women should also show their abilities to a political party that they can work and lead the commune or villages. Then, women will be given an opportunity to become local political candidates.

\subsubsection{Conclusion}

The resources section above illustrates a number of important factors that enable women to be able to become leaders at the commune and village levels. The experiences of the participants brought up six main external factors:

- Reforms/policies from the government,

- NGOs' activities,

- Wealth,

- Family support,

- Villagers and mentoring supports, and

- Knowing the political ropes and having good connections. 
Today, women local leaders have more opportunity to get involved in local politics because of the government reforms. They also receive training provided by some NGOs to develop their capacity. Beyond that, women are also encouraged by their family, villagers and male and female co-workers, and people in political parties to pursue their leadership dream. Women's additional income from their own family businesses or farming can maintain their standard of living, so they can devote their energy to the work. Poor women cannot go far or help others because they are trapped in poverty. It is therefore this unique combination of external factors, combined with internal factors that can help some women fulfil their leadership potential. 


\section{Chapter 5: Discussion}

The findings chapter answered research questions number one and two (1. What type of work, characteristics, and resources influence women to become local leaders? 2. What are the experiences that female local leaders have been through?), but it does not fully answer question number three which asked for a practical leadership model that would help guide other women to become local leaders. Thus, this discussion chapter will scrutinise how local women can reach their leadership positions. The type of work, characteristics and resources needed for this to happen will be developed after comparing the conceptual framework in Chapter 2 (Figure 2.1) and the actual findings in Chapter 4.

In comparing the conceptual framework and the findings, it is to be noted that the three main themes of the type of work, characteristics, and resources shown in Figure 2.1 are still the dominant factors. However, some adjustment to the conceptual framework has to be made. In the following section, the sub-themes will be discussed. They will be reordered according to a new element of time, namely the past, present, and future. This allocated timeframe hopes to create a convenient pathway for future local women leaders to follow. The future will be discussed in the recommendations chapter on what should be done to have more women readied for serve local leadership roles.

\subsection{Past and Present}

Lessons learnt from the nine women local leaders' life stories, at both the commune and village levels, indicate that women leaders have been influenced by their past and present actions. However, there is no literature in Cambodia which develops a timeline, in combination with other sub-factors that portrays a clear pattern for women to follow. Ebihara (1968), Sin (1995), Lilja (2007), Ledgerwood and Vijghen (2002), Kim and Öjendal (2012), Maffii (2011), Prak and Schuette (2007), all just provide diverse findings on what women should do in order to reach leadership positions in different contexts. Ebihara (1968) focused on morality, literary, competence, good character, relative wealth and willingness to work for less money. Sin (1995) raised

political ropes, networking, loyalty, encouragement, determination, and past 
experience in social struggles. Lilja (2007) gives more importance to education that can build women's confidence. Ledgerwood and Vijghen (2002) argued that kinship and patronage in a cultural context is what Cambodian women should focus on. Maffii (2011) claims that family support can help women gain leadership. Prak and Schuette (2007) state that women are freer to go outside of the house and that they are often involved in the social and economic sphere because they become an income source for their family.

Kim and Öjendal (2012) agreed that all the factors above are important for women, but they claim that government reforms and NGOs' activities should be also considered. These authors actually helped this study to find key factors that influence women, but they did not draw a clear connection between each factor. Thus, if local women want to reach a leadership position in the future, this study suggests that past and present divisions will be a uniting umbrella for three main themes including type of work (work experience), characteristics (internal factors) and resources (external factors). Women need to understand that their past working experience is important, and that they should build up their local working experience as well as improve their internal strength, and at the same time gain external support. Additionally, deriving from the empirical information and the conceptual framework, this study found that working experience, internal and external factors are all interlinked and interwoven as discussed in the sections below.

\subsubsection{Work experience}

The three types of leaders commune chief, commune councillor and village leader linked their current positions to their past local working experiences. Their experiences were usually relevant to local development by which they had already built their interaction with villagers. Thus, their past working experience became concrete proof for them to show villagers, and people in political parties, that they had the ability to handle the offered job whether it be to serve the commune or the village. Hence, this finding supports Sin's (1995) work stating that past experience is crucial for local women. Moreover, work experience is also the stepping stone for local women to move up from one position to another position. For instance, their work trend is usually to move from village volunteer or local NGO worker to village committees and to commune councillors. Neither the international literature nor the 
Cambodian literature discusses this trend. Thon et al. (2009) described the history of work experience of some local leaders, both men and women, but they did not claim that work experience is a means for women to become leaders. Therefore, the trend of building work experience is a key finding in this study.

However, to be able to have those work experiences, there are some criteria that women should also meet, for instance, having some education and certain internal and external factors, which will be described below.

\subsubsection{Internal factors}

Apart from working experience, this study found that women also needed four main internal strengths in order to be able to become local leaders. These were an education, personal drive, bravery/confidence and gentle/soft/moral/friendly character. First, without education, women could not become local leaders because they have to perform administrative tasks and other activities described in the sub-decree on Decentralisation of Power, as well as roles and duties to commune/Sangkat councils. A minimum of a primary education was thought to be sufficient for women local leaders. With that education level they can read and write properly and they can respond to the commune and village's tasks, something also stated in Thon et al. (2009). Presumably, when women have that basic knowledge, they can receive information and understand what is right and wrong. This can enhance their confidence to lead other villagers. This confirms earlier studies by Ebihara (1968), Lilja (2006), and Nguon (2000).

Secondly, personal drive is influenced by the surrounding context when women see social problems and when they want to take part in dealing with these problems. This finding confirmed the work of Sin (1995) when she states that personal drive can overcome all challenges that women have to face. Women understand that their contribution can change and help society to some extent, although they know that they will not get much financial benefit from it. Next, to make it happen, the bravery and confidence that Nguon (2000) and Lilja (2006) have pinpointed, will encourage women to find leadership positions and accept the opportunity to lead. Finally, women should develop their own characteristics because it is the key to gaining people's trust and support. From the findings, villagers or voters expect their female local leader to be gentle, soft, moral, and friendly. If women can develop these 
characteristics, it might be easier for them to get votes/support from followers and colleagues. Interestingly, women local leaders are widely recognised as being more approachable and kind, patient and generous than male local leaders (Kim \& Öjendal, 2012).

However, while confidence, personal drive and education are very important, women were also influenced by the governmental reforms or policies, NGOs activities, and support from others. These matters are discussed in the next section.

\subsubsection{External factors}

On top of the internal factors, women were also affected by a number of external factors. Without support from the government, civil society organizations, their own resources (wealth), family members, villagers and others, and knowing the political ropes, women could not proceed into local leadership roles. These factors did not emerge from these findings alone, but were actually suggested by the work of Ledgerwood and Vijghen (2002),Lilja (2006), Maffii (2011), and Kim and Öjendal (2011). All of these factors create a convenient way for women to walk into leadership positions. It is to be noted that the government's reforms and policies are one of the driving forces which are helping more women to participate in local politics.

Most participants in the study recognized the importance of the government reforms and policies and their effect on local women. Kim and Öjendal (2011) also claim that this is because women are the backbone of society. Women know women's matters better than men and currently women and children are the most vulnerable in society. They face poverty, domestic violence, land grabbing, other conflicts, and health and education issues. Hence, women are given more opportunities to become leaders because they seem to be active in dealing with these problems and are committed to develop both economic and social affairs in their community. Nevertheless, the results of the implementation of the government's policies or reforms on women and local leadership remain debatable and challenging because women are still underrepresented in local politics (Kim \& Öjendal, 2012, 2014; Thon et al., 2009).

NGOs interfere and attempt to reduce the challenges women face and this study shares the same view with Kim and Öjendal (2012) who state that NGO activities play a major role in increasing women participation in local leadership. NGOs provide 
training and build up women's confidence and willingness to work for their own community via leadership roles. They also teach the idea of gender equality to both men and women at the local level. Thus, colleagues, family members and villagers can understand women better, so make easier the pathway for women to participate in local politics.

Regarding their own resources, it is important to note that women local leaders are expected to be relatively wealthy. This finding supports one of the key findings of Ebihara (1968) showing that leaders at the local level must be relatively wealthy. This is because when women are not trapped in extreme poverty, they have the time and ability to work for the commune or villages. Working in the commune and village sometimes take a lot of private time and one's own money too. It is interesting to note that the monthly salary that women local leaders receive from commune and village's salary is not enough for them to survive on. Hence, they all must have additional income from farming, gardening, and minor businesses to supplement the expenses of their households. It seems that women have more burdens when they became leaders. They have to work for the commune and village, but also work at other jobs to get additional income. Moreover, they have also to look after their children and husband. Most women local leaders in the findings received support from family and relatives to reduce these burdens.

Family were not found to be a big burden in the study. With the support from family, especially from their husbands, women can fully engage in leadership positions. Family connections for women were also described as one of the strong networks for women which assisted them in their journey toward leadership roles (Lilja, 2006). What can be learnt from the findings is that most of the women local leaders' husbands are people who work, or used to work for the government at the local level. Some are former commune chiefs, teachers, and district commune councillors. Thus, they understand local problems, the nature of the work at the local level, and gender issues. Women leaders seemed to be lucky to have husbands who were encouraging and supportive. Family members were found to be supportive for women local leaders in terms of household chores. Some women local leaders who were widows seemed to be free from household chores because they did not have to prepare meals for their husbands or ask for agreements on any issue. Although these widow leaders were care 
free and had no husband to support them, they still needed the support of others to keep them motivated to work as local leaders.

Villagers and the support of others was another influential factor in women becoming leaders, but how to get such support is the question. To have a clear answer, women should be people who have lived in the same commune or village for a long time, or have been born there. This enables villagers and others (political party' members or local authorities) to get to know their background and to build relationships with them. This is social capital which women should develop within their own community (Eagly \& Carli, 2007; Lilja, 2006). Villagers and others often select their local leader, only if they are familiar with him or her.

Beyond the normal relationships as discussed above, women also have to have their political ropes, as suggested by Sin (1995). These ropes can pull and tie them to become a member in a particular political party before they are elected or selected to be leaders. This is because the political parties are the gatekeepers for women to access their local political arena (Kim \& Öjendal, 2014). The rope is the person whom women leaders used to work with or someone that they used to know and have a good relationship with. That person will build a connection between the women and the political parties. Thus, it is important to note that women should create this kind of network because it will be a bridge for them to go quickly into local politics. The ability of women, which was stated in the working experience and internal factors sections, is still relevant. Knowledge of their ability results in women being approached by the political parties. The selection process in the political parties also looks at women's background and their experience in working with local villagers. The more women have a good reputation in the village, the more they will be sought out by the political parties to become their members/candidates. The network approach is still the tendency in Cambodian culture where power rests with a boss in the political parties (Kim \& Öjendal, 2014). Therefore, knowing the political ropes within political parties can easily move women up into leadership positions.

From the comparison between the empirical findings and the original conceptual framework (as shown below), this discussion chapter concludes that this study supports key factors under the three main themes that influence women to become leaders discussed in the literature cited above. The significance of this study is that it combines all factors and rearranges them and puts them into a new logical pattern of a 
leadership pathway as shown in Figure 5.1. It illustrates clearly the flow that is helpful for a particular context like Cambodia.

Figure 2.1: Internal and External Factors that Influence Women Leaders (old)

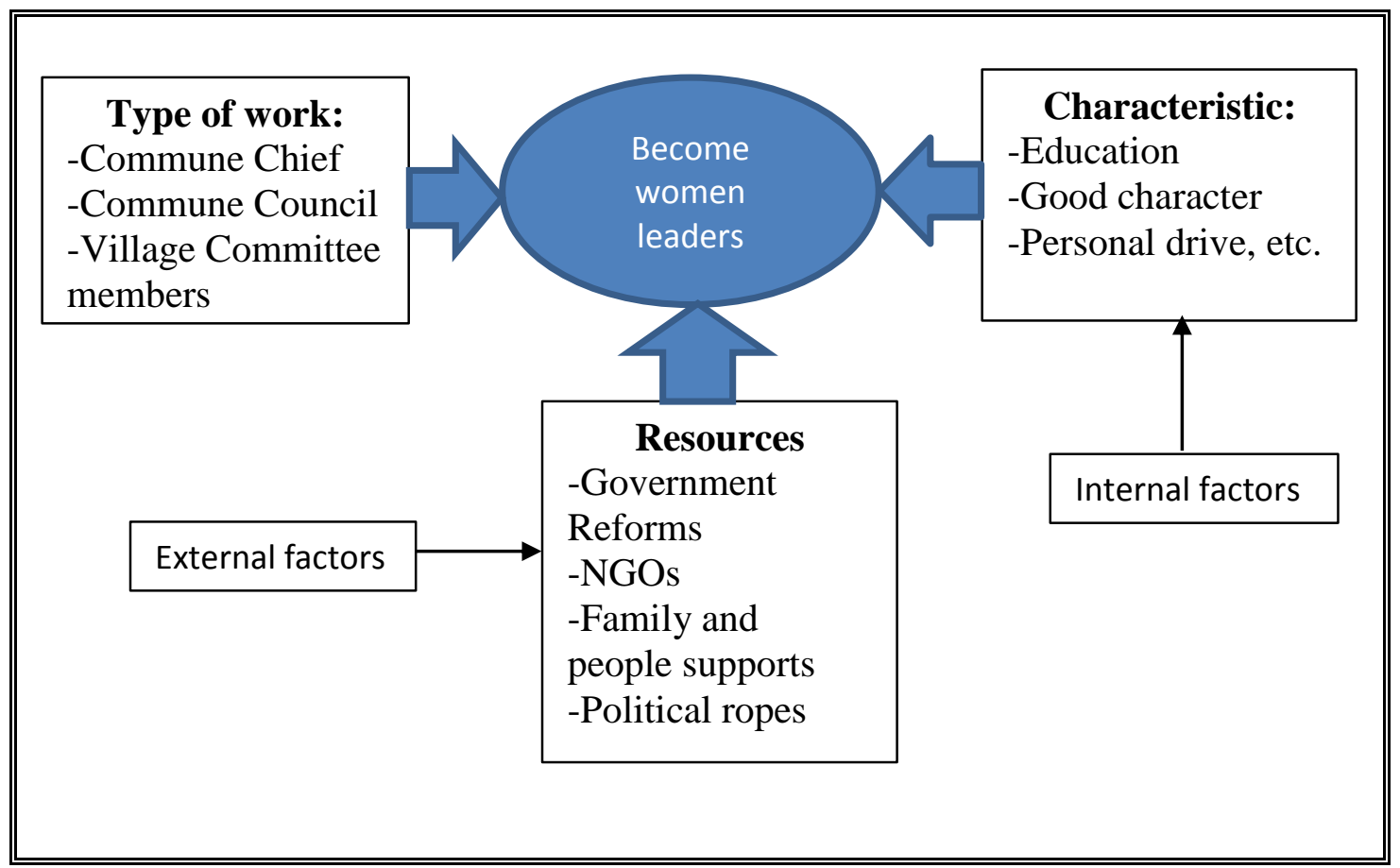

Sources: (Ebihara, 1968; Kim \& Öjendal, 2011, 2012; Ledgerwood \& Vijghen, 2002;

Lilja, 2006; Maffii, 2011; Silaka, 2011; Sin, 1995) 
Figure 5.1: Practical Leadership Pathways for Women in Cambodia (new)

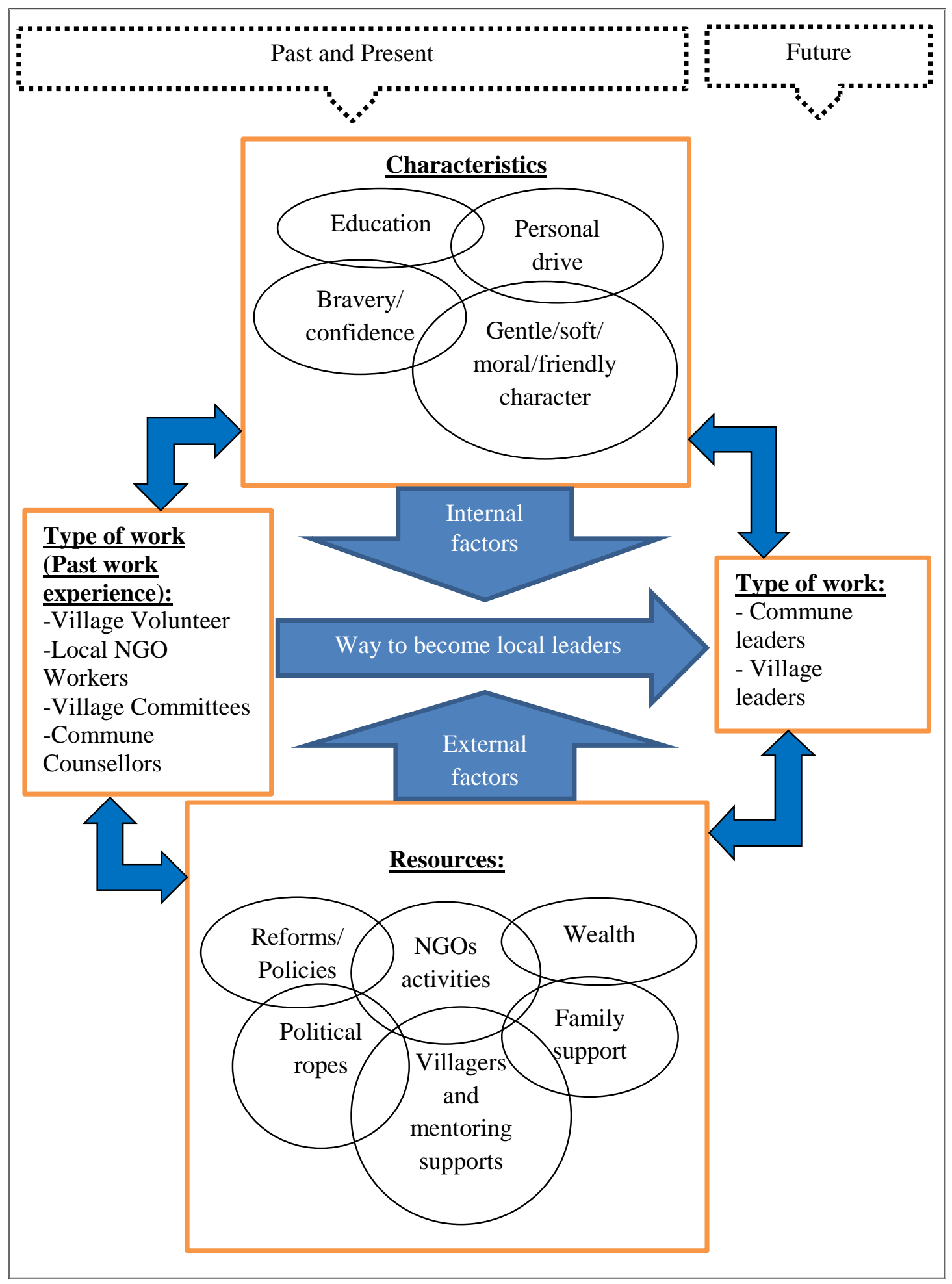




\section{Chapter 6: Conclusion and Recommendations}

\subsection{Conclusion}

Women leaders are very important for the development of Cambodia. They take good care of basic needs, such as domestic duties, health, education, and women's issues. However, the lack of representation of women in local politics has been seen as a problem which has led to the exclusion and disempowerment of women as well of their interests. It has also been seen as something that has slowed down local development, especially in the North-Eastern province of Cambodia. This study has focused on the success of nine women local leaders in the North-Eastern province to provide a possible model for leadership development for other women in society. The thesis has developed a practical leadership model that is designed to increase women's participation in local politics. The point is not to find out an exact model that every woman can apply in order to become a leader. Rather the aim is to develop a general pattern that provides a better understanding of all that leadership involves- a pattern which may pave a way for future women local leaders to follow.

Three main questions were posed: first, what type of work, characteristics, and resources influence women to become local leaders? Secondly, what are the experiences that female local leaders have been through? Lastly, (a) what can be learned from women's backgrounds and experiences and (b) how do these experiences contribute to the formation of a practical leadership model to help guide other women aspiring to be local leaders? It was clear that there had not been enough academic effort to understand these matters, particularly within the specific context of Cambodia. Accordingly, a case study approach was used to understand the local leadership context of three communes in three provinces and it helped to answer the three main questions above. Thus, the basic aim of the study was to understand the complexity of the real-life situations of women and to explore how they become local leaders.

Answers to these questions are reviewed below. The research context and the fieldwork relating to various problems worked well and the findings provided rich information to help answer the research questions. 


\section{Key findings:}

From the fieldwork and analysis of the data, a practical model was developed that extended previous models in the literature. This model focuses on three important themes including women's work experience, internal factors and external factors (See Figure 5.1 in Chapter 5), This is because they are still the influential factors, except that the sub-themes are rearranged from other models. These themes are all interwoven and linked because they relate to women's actions both in past and present contexts.

With regard to work experience, women, who are seeking leadership, should understand that their past work experience is very important. Their work experience is the foundation and evidence that give women a chance to be selected for leadership. In particular, women need past work experience which is relevant to local development, which tests their ability to deal with complex issues and allows them to learn how to connect with the local people. Their work experience is a stepping stone to move up from a lower position to a higher one. However, in addition to building up their work experience, women also need to develop their "internal factors" and to receive support from "external factors".

"Internal factors" include such things as education, personal drive, bravery/confidence, and a gentle/soft/moral/friendly character. In other words, their "internal factors" are a driving force which prompt and qualify women to be leaders. First, women need education so that, when leaders, they may be able to fulfil the responsibilities associate with commune and village life. In this commune and village context, education does not mean that women must have a higher education. A minimum education which enables them to read and write is enough. Second, a woman's personal drive is the powerful motivation that pushes them to take part in helping their own society. This is especially so when they see injustice, violence, and conflicts happening to villagers, many of whom are women and children. Next, women need bravery and confidence to make their goals become a reality when a leadership opportunity is given to them. Lastly, women local leaders must be characterised by having gentle, soft, moral and friendly attitudes. This is because these characteristics are demanded by their followers and their male counterparts, all of whom are partly shaped by Cambodian culture. Some internal factors may be difficult 
for some women to practise, but the external factors which will be described below, will be an incentive and provide opportunities for them to take up leadership positions.

Apart from "internal factors", "external factors" also play important roles in increasing the participation of women in their local politics. These external factors are chiefly, the government's reforms and policies, the organisation of civil society, personal resources (wealth), family support, support from villagers and others, and support arising from connections with political parties. First, women are recognised as important key players in helping communities to escape out of poverty. Thus policy makers and the government have created laws, policies and strategies to reduce gender disparity at local level. Women are been given more opportunities to be representative at commune and village levels. For instance, a woman should at least be part of the village committee members. There, however, there are challenges for women. Thus, many NGOs step in and contribute their help in speeding up the aims of government to have more women in local politics. Through the NGOs' programmes women are trained and their confidence to become leaders is also daily build up. For instance, women and leadership programmes are run by PYD, VFP, KADOC, and Silaka.

Women leaders are expected to be relatively wealthy. The reason for this is that if they are not trapped in extreme poverty, they will have the time and resources to help other villagers. Furthermore, women leaders need support from their families with regard to household chores and taking care of children. Along the way, the support of villagers and that of others (female leaders and male co-workers) is necessary in order to encourage new women leaders to take the lead in the affairs of their communes and villages. Lastly, political parties are, to some extent, the gatekeepers which open the way for women to join in local politics. Thus, women should build up their networking with their political parties. Then, they will be introduced into the parties and selected by their network to stand for local political committees. By doing so they will gain their local leadership skills quickly and more efficiently. Each of these factors gives women time and space to move outside of their home where traditionally and culturally, they are meant to be busy in the kitchen and with their children.

In brief, this study acknowledges and supports some key findings from previous authors. However, from the empirical findings and in combination with the literature, this study has adjusted and developed a new pattern for a leadership pathway (Figure 5.1). It provides a clearer structure and identifies key main themes and sub-themes 
that will bring Cambodian women to significant positions in local politics. First, women should build up their local working experience. Next, women need to develop their personal character. Lastly, women need strong support from various external factors. The study concludes with some recommendations for the various actors in Cambodian society for ways in which they can support and encourage women to take up leadership positions.

\subsection{Recommendations}

If in the future we want to see more women participate in local politics, then the pattern of leadership pathway that this study suggests could be followed by women in the North-Eastern province. The pathway does involve many actors who along with women themselves, play significant roles in the pattern of local leadership. Thus, the study makes the following recommendations which could be considered by all these actors - that is by the government, by civil society organizations (NGOs), by family and villagers, by both men and women members of political parties, by those at the work place, and of course, by all women.

- The government:

- Should continue their reforms and policies and put these into practice as much as they can, so women will have more voice in expressing themselves in the local political arena. Since a successful case reveals that at least one woman should work in each village, the government ought, accordingly, to create a new policy stating that at least two women commune councillors should work in each commune office. If this policy is inaugurated, then more women will be accepted at the local level. The government should create arrangements that support an environment in which women may work for village or commune while, at the same time, they can also be responsible for their family or other business and employment.

- Should educate husbands of other local women and villagers to understand how important it is to allow women become a leader and be part of sustainable development processes. This can be generated through local meetings and media. 
- Civil society organization (NGOs): Since both women and current women local leaders still find themselves lacking leadership skills and knowledge, NGOs should continue their effort in building up women's capacity. Women need training programmes in order to learn how to increase their confidence, how to do administrative work, how to solve conflicts, and how to interact with villagers and male co-workers. In addition, since Cambodian women are still subjected to the age-old customs of hierarchical society, equal rights between men and women should be advocated, especially in remote areas.

- Family: Husbands and family members should continue their support of women aspiring to be leaders by sharing household responsibilities, and the daily household business, with each other.

- Villagers, male and female members of political parties and those who work at the commune and village: They all should continue their support and encouragement, so women will have the motivation to move on in their leadership career.

- Women: They should spend time getting involved in local meetings both formal and informal because this will create a relationship with villagers and build up networking with others that may help women to become leaders in the future. If women dare to make changes, then their life, and that of others will change for the better.

All actors above should work with each other and give women more opportunities to test themselves and so be able to step into the local leadership arena. Education of all actors can be done through using Figure 5.1 as a map in media, dissemination workshops or public campaigns, so then the government and NGOs know where, when and how to develop their own programmes to fit into the three main themes and the sub-themes accordingly. The internal and external factors that influence women need to be worked on and discussed among all of the actors above. Therefore, each of their efforts will supplement each other and avoid duplication and inefficiency. In this way women and men can see that there is a pathway for women to take to develop their leadership potential and serve their local communities. 


\section{Appendices}

\section{Appendix 1}

$\underline{\text { Sample interview guide }}$

\begin{tabular}{|c|c|c|c|}
\hline \multirow[t]{2}{*}{ Time } & \multicolumn{2}{|c|}{ External factors } & \multirow{2}{*}{$\begin{array}{l}\text { Internal factors } \\
\text { Characteristic }\end{array}$} \\
\hline & Type of work & Resources & \\
\hline I. & \multicolumn{3}{|c|}{ Interview with key informants } \\
\hline Past & $\begin{array}{l}\text { 1. Where did you } \\
\text { live in the past? } \\
\text { 2. When did you } \\
\text { begin your } \\
\text { career as a } \\
\text { leader? } \\
\text { 3. When and how } \\
\text { did your } \\
\text { experience of } \\
\text { leading begin? } \\
\text { (who told you } \\
\text { that you could } \\
\text { be leadership } \\
\text { material? Who } \\
\text { encouraged } \\
\text { you?) }\end{array}$ & $\begin{array}{l}\text { 13. Could you tell } \\
\text { me about any } \\
\text { family members } \\
\text { or other people } \\
\text { who inspired } \\
\text { you by their } \\
\text { leadership? } \\
\text { What did you } \\
\text { admire about } \\
\text { them? } \\
\text { 14. How can you } \\
\text { deal with work- } \\
\text { family conflict? }\end{array}$ & $\begin{array}{l}\text { 25. What is your } \\
\text { educational } \\
\text { background? } \\
\text { 26. Are you } \\
\text { satisfied with } \\
\text { this education } \\
\text { level? }\end{array}$ \\
\hline Present & $\begin{array}{l}\text { 4. What is your } \\
\text { current position? } \\
\text { 5. Do you have } \\
\text { other roles and } \\
\text { responsibilities } \\
\text { beside your } \\
\text { current one? } \\
\text { 6. Do you enjoy } \\
\text { your current } \\
\text { career? } \\
\text { 7. How long have } \\
\text { you been in this } \\
\text { position? How } \\
\text { did you get into } \\
\text { this role? } \\
\text { 8. In terms of your } \\
\text { location context, } \\
\text { what have } \\
\text { influenced your } \\
\text { aspiration and } \\
\text { practice of } \\
\text { leadership? } \\
\text { 9. How can you } \\
\text { overcome }\end{array}$ & $\begin{array}{l}\text { 15. What influences } \\
\text { you in your } \\
\text { practice of } \\
\text { leadership? } \\
\text { (Married life? } \\
\text { children? role } \\
\text { of your } \\
\text { husband?) } \\
\text { 16. Have you ever } \\
\text { been in any } \\
\text { training } \\
\text { programme run } \\
\text { by NGOs } \\
\text { relevant to } \\
\text { women and } \\
\text { leadership? } \\
\text { Was it helpful? } \\
\text { 17. How do you } \\
\text { develop your } \\
\text { leadership role? } \\
\text { 18. How do you } \\
\text { maintain your } \\
\text { career and cope } \\
\text { with barriers? }\end{array}$ & $\begin{array}{l}\text { 27. What gives } \\
\text { you } \\
\text { confidence to } \\
\text { be a leader? } \\
\text { 28. Do you think } \\
\text { your public } \\
\text { speaking is } \\
\text { effective? } \\
\text { Why? } \\
\text { 29. Describe your } \\
\text { personality. } \\
\text { 30. What pushes } \\
\text { your personal } \\
\text { drive? } \\
\text { 31. What are your } \\
\text { main talents? } \\
\text { 32. What kind of } \\
\text { leader are you? } \\
\text { 33. What is most } \\
\text { important to you } \\
\text { as a leader? } \\
\text { 34. Could you } \\
\text { describe your } \\
\text { leadership style? }\end{array}$ \\
\hline
\end{tabular}




\begin{tabular}{|c|c|c|c|}
\hline & $\begin{array}{l}\text { traditional } \\
\text { stereotype? } \\
\text { 10. Are women } \\
\text { leaders in rural } \\
\text { areas different } \\
\text { from women } \\
\text { leaders in the } \\
\text { cities? }\end{array}$ & $\begin{array}{l}\text { 19. How have you } \\
\text { achieved your } \\
\text { current role? } \\
\text { (Give specific } \\
\text { events). } \\
\text { 20. How do you } \\
\text { currently } \\
\text { participate in } \\
\text { your political } \\
\text { party? } \\
\text { 21. How would you } \\
\text { describe your } \\
\text { relationship } \\
\text { with your male } \\
\text { counterparts? } \\
\text { 22. Are there any } \\
\text { incidents when } \\
\text { you have been } \\
\text { at a low point } \\
\text { and felt like } \\
\text { giving up, and } \\
\text { what has } \\
\text { inspired you to } \\
\text { keep going? } \\
\text { 23. How have the } \\
\text { government } \\
\text { reforms have an } \\
\text { impact on } \\
\text { women and } \\
\text { leadership? }\end{array}$ & $\begin{array}{l}\text { Is it more on } \\
\text { democratic style } \\
\text { or others? }\end{array}$ \\
\hline Future & $\begin{array}{l}\text { 11. What is your } \\
\text { dream as a } \\
\text { women leader? } \\
\text { 12. What do you } \\
\text { want to } \\
\text { achieve as a } \\
\text { leader? How } \\
\text { will you look } \\
\text { after yourself } \\
\text { in the process? }\end{array}$ & $\begin{array}{l}\text { 24. What kind of } \\
\text { support you } \\
\text { would need to } \\
\text { help other } \\
\text { women become } \\
\text { leaders? }\end{array}$ & $\begin{array}{l}\text { 35. Do you have } \\
\text { any } \\
\text { recommendatio } \\
\text { ns to improve } \\
\text { other women's } \\
\text { confidence? }\end{array}$ \\
\hline
\end{tabular}

\section{Interview with focus group discussion}

Sole focus: to identify a leadership model that can help women who want to be leaders? What factors influence them?).

\section{Main questions:}

1. How can more women become leaders?

2. What kind of characteristic do you want to see in your future women 


\begin{tabular}{|c|}
\hline $\begin{array}{l}\text { leaders? } \\
\text { 3. What are the differences between women leaders in your commune } \\
\text { and women leaders in the cities and elsewhere? }\end{array}$ \\
\hline $\begin{array}{l}\text { Some of the sub-questions below may be raised in the discussion based on real } \\
\text { situation. }\end{array}$ \\
\hline - Past \\
\hline 1. Previously, did you have women as your local leaders? \\
\hline 2. What was their position? \\
\hline 3. How did they get into these leadership positions? \\
\hline 4. How did they lead your commune? \\
\hline 5. Were there many of women leaders in your commune or village? \\
\hline 6. Why do you think that was the case? \\
\hline 7. What personal attributes did local leaders base their leadership on? \\
\hline 8. Are these attributes still important today? \\
\hline - Present \\
\hline 9. Do you like women's leadership style? \\
\hline $\begin{array}{l}\text { 10. How would you describe women's leadership style? How does it compare } \\
\text { to men's leadership style? Which do you prefer and why? }\end{array}$ \\
\hline 11. How do they interact/ communicate with villagers? \\
\hline 12. What have been their achievements in the commune? \\
\hline 13. How did they achieve it? \\
\hline $\begin{array}{l}\text { 14. Are women good at those positions (it can be Commune Chief, councillor, or } \\
\text { village committee)? }\end{array}$ \\
\hline $\begin{array}{l}\text { 15. What influences current women leaders do you think? (Married life? } \\
\text { children? role of your husband? etc). }\end{array}$ \\
\hline $\begin{array}{l}\text { 16. How can more women become leaders? Through help from NGOs or } \\
\text { government reforms? }\end{array}$ \\
\hline $\begin{array}{l}\text { 17. Do you think women need networking? And political ropes? Why this kind } \\
\text { of network is important? }\end{array}$ \\
\hline $\begin{array}{l}\text { 18. What is the most important factor for women to focus on at the moment if } \\
\text { they want to be leaders? }\end{array}$ \\
\hline 19. Do you like their personalities? Why or why not? \\
\hline 20. Do you like the way they lead your commune or village? Why or why not? \\
\hline - Future \\
\hline 21. Do you want to see more women leaders in future? \\
\hline 22. What kind of issues do you want them to take part in? \\
\hline 23. What kind of service do you want to get from women leaders? \\
\hline 24. What will more women need to become leaders? \\
\hline 25. What kind of support should they have or will they need? \\
\hline
\end{tabular}

\section{*Participation observation in both formal and informal local meetings conducted by female leaders:}

- How do women leaders interact with local villagers?

- Are people satisfied with their leadership? In what way?

- Observe her behavior. 


\section{Appendix 2}

TE WHARE WĀNANGA O TE ŪPOKO O TE IKA A MĀUI

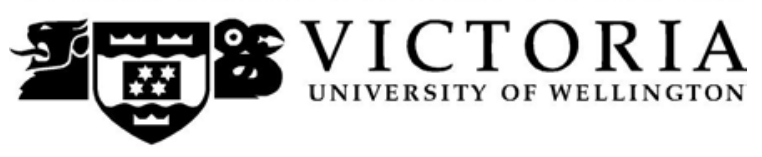

MEMORANDUM

Phone $\quad 0-4-4635676$

Fax $\quad 0-4-4635209$

Email_Allison.kirkman@vuw.ac.nz

\begin{tabular}{l|l}
\hline TO & Tem Ly \\
\hline COPY TO & Sara Kindon \\
\hline FROM & Dr Allison Kirkman, Convener, Human Ethics Committee \\
\hline
\end{tabular}

\begin{tabular}{l|l}
\hline DATE & 26 April 2014 \\
\hline PAGES & 1 \\
\hline
\end{tabular}

\section{SUBJECT Ethics Approval: 20850}

\begin{tabular}{l|l}
\hline & $\begin{array}{l}\text { Women and leadership: How do women become local } \\
\text { leaders? Case studies of three communes in three provinces } \\
\text { of Cambodia }\end{array}$ \\
\hline
\end{tabular}

Thank you for your application for ethical approval, which has now been considered by the Standing Committee of the Human Ethics Committee.

Your application has been approved from the above date and this approval continues until 28 February 2015. If your data collection is not completed by this date you should apply to the Human Ethics Committee for an extension to this approval.

Best wishes with the

research. Allison Kirkman

Human Ethics Committee

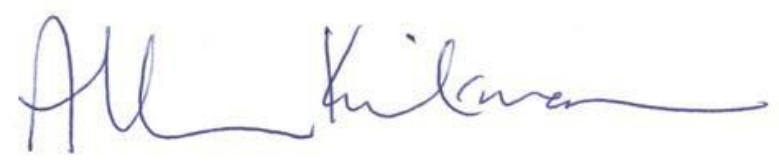




\section{Appendix 3}

TE WHARE WANANGA O TE OPOKO O TE IKA A MÃU

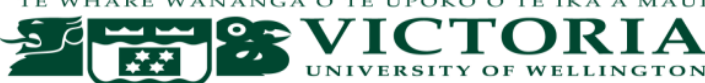

\section{Participant Information sheet for key informants}

Researcher's name: Tem LY

\section{Address: \#604, Sangkat Stung Mean Chey, Khan Mean Chey, Phnom Penh, Cambodia}

\section{School of Geography, Environment and Earth Sciences, Victoria University of Wellington}

I am a master's student in development studies at Victoria University of Wellington. As part of this degree, I am undertaking a research project leading to a thesis. The project I am undertaking is developing a practical leadership model that can help to increase more women's participation in local politics. This research has been granted ethic approval from Victoria University Human Ethics Committee.

The study will use multiple techniques, including key informant interviews, focus group discussions, participation observation, informal interviews and documentation and analysis of archival records.

I am inviting female local leaders as my key informants including female commune chiefs, female commune councillors, and female village committee members. Three or four of key informants in each commune will be conducted. In-depth interviews will be held with key informants for around one hour to explore their real-life situations and experiences. The conversations will be continued further if participants are interested in telling their life stories. When carrying out the interviews, some questions will be asked. Permission for audio recording will be requested. I will record or note the interviews which may take place in participants' houses, commune offices or somewhere else convenient. Repeat interviews will be conducted to verify facts. I will conduct the informal interviews and do observation when there is a commune meeting or other informal meetings in communes between key informants and other people. 
It is important for participants to get involved because their responses will build a better understanding for the government and NGOs who are working to promote more women taking leadership roles at local level. This will be an empowerment mechanism to challenge inequality and poverty at the grass-root levels.

You will have the right to withdraw from the interview process at any time [before June, 30 $0^{\text {th }} 2014$ ] and you can refuse to answer any of interview questions. You should let me know at the time.

The data from interviews and discussions will be put into an academic thesis and a written report. The names of the key informants and others will be changed and coded to protect your identities. Information will be concealed when conducting interviews to avoid conflict or breaking social bonding. All material collected will be kept confidential. No other person besides me and my supervisor, Dr. Sara Kindon, will see the transcript of the interviews and focus groups. The thesis will be submitted to the School of Geography, Environment and Earth Sciences and deposited in the Victoria University Library. It is intended that one or more articles will be submitted for publication in scholarly journals. All data will be destroyed two years after the end of the project.

I will provide summaries of the research report to you after my fieldwork in June If you have any further questions, or would like to receive further information about the project, please contact us on temchung@myvuw.ac.nz or my supervisor [Dr. Sara Kindon], at the School of Geography, Environment and Earth Sciences at Victoria University4636194 and sara.kindon@vuw.ac.nz.

\section{Tem LY}




\section{Participant Consent form}

Title of the project: Women and leadership: How do women become local leaders? Case studies of three communes in three provinces of Cambodia.

I have been given explanation of this research project and have understood it. I have had the opportunity to ask questions and have them answered to my satisfaction. I understand that I may withdraw myself or any information from this project you emailing you at temchung@yahoo.com or phone: +64223897414 before June 30 2014 without having to give reasons.

I understand that any information I provide will be kept confidential to the researchers. I understand the published results will not use my name, and that no opinions will be attributed to me in any way that will identify me. I understand that the tape recording of interviews will be erased at the end of the project unless I indicate that I would like them returned to me.

Signed:

Name of participant:

Date: 


\section{References}

Acocella, I. (2011). The focus groups in social research: Advantages and disadvantages Qual Quant, 2012(46), 1125-1136.

Antonakis, J., Cianciolo, A. T., \& Sternberg, R. J. (2004). Leadership: Past, present, and future. In J. Antonakis, A. T. Cianciolo, R. J. Sternberg \& F. H. Cardoso (Eds.), The Nature of Leadership (pp. 3-15). California, London, and New Delhi: Sage Publication.

Appelbaum, S. H., Audet, L., \& Miller, J. C. (2003). Gender and leadership? Leadership and gender? A journey through the landscape of theories. Leadership \& Organization Development Journal, 24(1), 43-51.

Bertelsmann Stiftung's Transformation Index. (2012). Cambodia country report. Gütersloh: Bertelsmann Stiftung.

Brickell, K. (2008). 'Fire in the house': Gendered experiences of drunkenness and violence in Siem Reap, Cambodia Geoforum, 39(5), 1667-1675.

Bryman, A. (2008). Social reserach methods. Oxford and New York: Oxford University Press.

Burns, J. M. (1978). Leadership. New York, NY: Harper Torchbooks.

Cambodian Center for Human Rights. (2013). Politics in the Kingdom: Increasing female representation. Phnom Penh: Cambodia.

Cameron, J. (2005). Focussing on the focus group. In I. Hay (Ed.), Qualitative research methods in human geography. Melbourne: Oxford University Press.

Cargan, L. (2007). Doing social research. United Kingdom: Rowman \& Littlefield Publishers, Inc.

Chandler, D. (1991). The tragedy of Cambodian history: Politics, war, and revolution since 1945. USA: Yale University Press.

Chum, S. (2010). NGO coordination and the changing aid environment in Cambodia: Challenges and opportunities. Masters in Development Studies, Victoria University of Wellington, New Zealand, Wellington.

Coleman, M. (2011). Women at the top: Challenges, choices and change. New York: Palgrave Macmillan.

Collins, W. A. (1998). Grassroots civil society in Cambodia. A discussion paper prepared for a workshop organized by Forum Syd and Diahonia. Phnom Penh: Center for Advanced Study.

Craft, C. L. (2012). Female workplace self-help books: Guiding women to become leaders. Master of Arts, Ann Arbor: Marshall University.

Denzin, N., \& Lincoln, Y. (2005). The Sage handbook of qualitative research. Thousand Oaks: Sage Publication.

Devarachetty, S. (2012). Women as charismatic leaders. PhD dissertation, The University of Akron, Ann Arbor.

Dey, I. (1993). Qualitative data analysis: A user-friendly guide for social scientists. London: Routledge.

Dingwall, R. (1997). Methodological issues in qualitative research: Accounts, interviews and observation. In G. Miller \& R. Dingwall (Eds.), Context and method in qualitative research. Thousand Oasks: Sage Publication.

Domosh, M. (2003). Towards a more fully reciprocal feminist inquiry. ACME: An International E-Journal for Critical Geographies, 2(1), 107-111.

Duerst-Lahti, G., \& Kelly, R. M. (1995). Gender power, leadership, and governance. Ann Arbor: The University of Michigan Press. 
Eagly, A. H., \& Carli, L. L. (2007). Through the labyrinth: The truth about how women become leaders. USA: Harvard Business School Press.

Ebihara, M. (1968). Svay, a Khmer village in Cambodia. PhD dissertation, Columbia University.

Eisenhardt, K. M. (1989). Building theories from case study research. The Academy of Management Review, 14(4), 532-550.

Giammatteo, M. C. (1981). Forces on leadership. Teston, VA: National Association of Secondary Principals.

Gorman, S., Pon, D., \& Sok, K. (1999). Gender and development in Cambodia: An overview. Phnom Penh: Cambodia's Leading Independent Development Policy Research Institute.

Griffin, C. (2004). The advantages and limitation of qualititve research in psychology and education. Scientific Annals of the Psychological Society of Northern Greece, 2, 3-15.

Griffith, L. (2010). Strengthening democracy and electoral processes in Cambodia:Lessons learned and best practices in promoting women participation and representation in Cambodia 2010. Phnom Penh: UNDP.

Halpern, D. F., \& Cheung, F. M. (2008). Women at the top: Powerful leaders tell us how to combine work and family. UK: Wiley-Blackwell.

Hoare, J., \& Gell, F. (2009). Women's leadership and participation: Case studies on learning for action. UK: Oxfam GB.

International Fund for Agricultural Development of the United Nations. (2003). Rural poverty reduction project in Prey Veng and Svay Rieng design documment. Draft working paper 2: Gender analysis and gender mainstreaming. Phnom Penh: IFAD.

Jackson, C., \& Pearson, R. (1998). Feminist visions of development: Gender analysis and policy London: Routledge.

Jamieson, K. H. (1995). Beyond the double bind: Women and leadership. New York: Oxford University Press.

Jensen, J. S. (2008). Women political leaders: Breaking the highest glass ceiling. New York: Palgrave Macmillan.

Jogulu, U. D., \& Wood, G. J. (2006). The role of leadership theory in raising the profile of women in management. Equal Opportunities International, 25(4), 236-250.

Johnson, D. G. (2009). The effect of sex and gender on perceptions of leaders: Does situation make a difference? Advancing Women in Leadership, 31, 40-44.

Kellerman, B., \& Rhode, D. (2007). Women and leadership: The state of play and strategies for change. San Francisco: Jossey-Bass.

Khy, S., \& Henderson, S. (2013). Government raises salaries for commune, village officials, The Cambodia Daily. Retrieved from http://www.cambodiadaily.com/archives/government-raises-salaries-forcommune-village-officials-41574/

Kim, S., \& Öjendal, J. (2011). A gender analysis of the decentralisation reform in Cambodia. Research Report No. 2. Visby: Swedish International Centre for Local Democracy.

Kim, S., \& Öjendal, J. (2012). A gendered analysis of decentralisation reform in Cambodia. Working paper series No. 71. Phnom Penh: Cambodia's Leading Independent Development Policy Research Institute.

Kim, S., \& Öjendal, J. (2014). Gatekeepers in local politics: Political parties in Cambodia and their gender policy. Working paper Series No. 87. Phnom 
Penh: Cambodia's Leading Independent Development Policy Research Institute.

Klenke, K. (1993). Meta-analytic studies of leadership: Added insights or paradoxes? Current Psychology, 12(4), 326.

Klenke, K. (1996). Women and leadership: A contextual perspective. New York: Springer Publishing Company.

Kobayashi, A. (2003). GPC ten years on: Is self-reflexivity enough? Gender, Place and Culture, 10(4), 345-349.

Kraynanski, J. M. (2007). Women walking silently: The emergence of Cambodian women into the public sphere. Master thesis, University of Ohio, United States.

Lapan, S. D., Quartaroli, M. T., \& Riemer, F. J. (2012). Qualitative research: An introduction to methods and designs. San Francisco: Jossey-Bass.

Ledgerwood, J., \& Vijghen, J. (2002). Decision-making in rural Khmer villages. In J. Ledgerwood (Ed.), Cambodia emerges from the past: Eight essays. DeKalb, IL: Center for Southeast Asian Studies, Northern Illinois University.

Lilja, M. (2006). Performance of resistance: Women's struggle for political power in Cambodia. Sweden: Department of Peace and Development Research, Göteborg University.

Lilja, M. (2007). Speaking of resistance: Women politicians negotiating discursive power in Cambodia. Göteborg: Göteborg University.

Lilja, M. (2008). Power, resistance and women politicians in Cambodia: Discourses of emancipation. Denmark: Nordic Institute of Asian Studies.

Maffii, M. (2011). Women's leadership: A case study from Cambodia. Phnom Penh: The Heinrich Böll Foundation.

Mansfield, C., \& Macleod, K. (2004). Commune councils and civil society: Promoting Decentralization through Parterships. Phnom Penh: Pact Cambodia.

McCauley, C. D. (2004). Successful and unsuccessful leadership. In J. Antonakis, A. T. Cianciolo \& R. J. Sternberg (Eds.), The nature of leadership. California: Sage Publication.

McGrew, L., Frieson, K., \& Chan, S. (2004). Good governance from the ground up: Women's roles in post-conflict Cambodia. Washington, D.C: Hunt Alternatives Fund.

Menh, N. (2009). Strengthening the voices of women leaders: Lessons from Cambodia. In J. Hoare \& F. Gell (Eds.), Women's leadership and participation: Case studies on learning for action. UK: Oxfam GB.

Mertens, D. M. (2012). Ethics in qualitative research in education and the social sciences. In S. D. Lapan, M. T. Quartaroli \& F. J. Riemer (Eds.), Qualitative research: An introducation to methods and designs (pp. 19-39). San Francisco: Jossey-Bass.

Mikkelsen, B. (2005). Methods for development work and research: A new guide for practitioners. New York: Sage Publishing.

Ministry of Planning. (2010). Achieving Cambodia's millennium development goals. Phnom Penh: Ministry of Planning.

Ministry of Women's Affairs. (2004). The progress report on implementation of Beijing platform for action on women issues 1995-2005. Phnom Penh: Ministry of Women's Affairs.

Ministry of Women's Affairs. (2005). Violence against women: A baseline survey. Phnom Penh: Ministry of Women's Affairs.

Ministry of Women's Affairs. (2008). A fair share for women: Cambodia gender assessment and policy brief. Phnom Penh: Ministry of Women's Affairs. 
Ministry of Women's Affairs. (2009). Five year strategic plan 2009-2013: Neary Rattanak III. Phnom Penh: Ministry of Women's Affairs.

Nagar, R., \& Raju, S. (2003). Women, NGOs and the contradictions of empowerment and disempowerment: A conversation Antipode: A Radical Journal of Geography, 35(1), 1-13.

National Election Committee. (2012). Number of women elected as commune council members of the 2007 commune council elections nation wide. Phnom Penh: National Election Committee.

National Institute of Statistics. (2011). Women and men in Cambodia 2011. Phnom Penh: Ministry of Planning.

Nguon, S. (2000). An overview of women in leadership in Cambodia. Paper for presentation at the Socio-Cultural Conference, November 15-17, 2000, University of Phnom Penh. Phonm Penh: Center for Advanced Study.

Parpart, J. (2008). Rethinking gender and empowerment. In V. Desai \& R. B. Potter (Eds.), The companion to development studies (pp. 355-358). London and New York: Routledge.

Prak, K. B., \& Schuette, S. (2007). Gender and women politics in Cambodia: Scoping study for the work of the Southeast Asia program of the Heinrich Böll Foundation, Cambodia. Phnom Penh: Heinrich Böll Stiftung.

Pym, C. (1968). The ancient civilization of Angkor. New York: The New American Library.

Reddock, R. (2000). Why gender? Why development? . In J. Parpart, M. P. Connelly \& V. E. Barriteau (Eds.), Theoretical perspectives on gender and development (pp. 23-50). Canada: International Development Research Center.

Reilly, B. (2007). Electoral systems and party systems in East Asia. Journal of East Asian Studies, 7, 185-202.

Rooney, D. F. (1994). Angkor today. Independent Scholars of Asia Newsletter, April, 1999, 9-11.

Royal Government of Cambodia. (2002). Sub-decree on decentralization of powers, roles and duties to commune/sangkat councils. Phnom Penh: Royal Government of Cambodia.

Rusten, C., Kim, S., Eng, N., \& Pak, K. (2004). The Challenges of Decentralisation Design in Cambodia. Phnom Penh: Cambodia's Leading Independent Development Policy Research Institute.

Sethi, G. (2013). Increasing women's political representation and participation in Cambodia through the implemenation of gender quotas. Phnom Penh: Heinrich Böll Stiftung.

Silaka. (2011). Key Notes: National Conference on Women in Cambodia on Women Moving towards Progress. Inter-Continental Hotel, 6-8th September: Phnom Penh: Silaka.

Sin, B. C. (1995). Women and leadership. Phnom Penh: The Asia Foundation and United States Agency for International Development.

Soy, S. K. (1997). The case study as a research method: Uses and users of information. University of Texas. Austin. Retrieved from https://www.ischool.utexas.edu/ ssoy/usesusers/1391d1b.htm

Sultana, F. (2007). Reflexivity, positionality and participatory ethics: Negotiating fieldwork dilemmas in international research. ACME: An International EJournal for Critical Geographies, 6(3), 374-385.

Sweetman, C. (2000). Women and leadership. UK: Oxfam GB.

The Asia Foundation. (2013). The role of women in Cambodia. Phnom Penh: The Asia Foundation. 
The World Bank. (2005). East Asia decentralised: Making local government work. Washington, D.C: The World Bank.

Thon, V., Ou, S., Eng, N., \& Ly, T. (2009). Leadership in local politics of Cambodia: A study of leaders in three communes of three provinces. Phnom Penh, Cambodia: Cambodia's Leading Independent Development Research Institute.

UNIFEM, WB, ADB, UNDP, \& DFID/UK. (2004). A fair share for women: Cambodia gender assessment. Phnom Penh: UNIFEM, WB, ADB, UNDP, DFID/UK.

United Nations. (2014). The millennium development goals report 2014. New York: United Nations.

United Nations Development Programme. (2011). Human development report 2011: Sustainability and equity: A better future for all. New York: UNDP.

USAID. (2006). Gender analysis \& assessment:USAID/Cambodia, Volume II: Gender assessment. Phnom Penh: USAID.

Willis, K. (2005). Theories and practices of development. New York: Routledge.

Women's Media Centre of Cambodia. (2012). Analysis of Cambodia

Commune/Sangkat council election. Phnom Penh: Women's Media Centre of Cambodia.

World Bank. (2012). World development indicators. Washington, D.C.: The World Bank.

Wright, S. (2012). Emotional geographies of development. Third World Quarterly, 33(6), 1113-1127.

Yin, R. K. (2003). Case study research design and methods. California: Sage Publications. 